\title{
Assessment of contrast enhanced mammography
}

Citation for published version (APA):

Houben, I. P. L. (2021). Assessment of contrast enhanced mammography: towards a full-fledged clinical tool for breast cancer diagnosis and screening. [Doctoral Thesis, Maastricht University]. Maastricht University. https://doi.org/10.26481/dis.20211108ih

Document status and date:

Published: 01/01/2021

DOI:

10.26481/dis.20211108ih

Document Version:

Publisher's PDF, also known as Version of record

\section{Please check the document version of this publication:}

- A submitted manuscript is the version of the article upon submission and before peer-review. There can be important differences between the submitted version and the official published version of record.

People interested in the research are advised to contact the author for the final version of the publication, or visit the DOI to the publisher's website.

- The final author version and the galley proof are versions of the publication after peer review.

- The final published version features the final layout of the paper including the volume, issue and page numbers.

Link to publication

\footnotetext{
General rights rights.

- You may freely distribute the URL identifying the publication in the public portal. please follow below link for the End User Agreement:

www.umlib.nl/taverne-license

Take down policy

If you believe that this document breaches copyright please contact us at:

repository@maastrichtuniversity.nl

providing details and we will investigate your claim.
}

Copyright and moral rights for the publications made accessible in the public portal are retained by the authors and/or other copyright owners and it is a condition of accessing publications that users recognise and abide by the legal requirements associated with these

- Users may download and print one copy of any publication from the public portal for the purpose of private study or research.

- You may not further distribute the material or use it for any profit-making activity or commercial gain

If the publication is distributed under the terms of Article $25 \mathrm{fa}$ of the Dutch Copyright Act, indicated by the "Taverne" license above, 
Assessment of contrast enhanced mammography:

Towards a full-fledged clinical tool for breast cancer diagnosis and screening. 
(C) Ivo Houben, Maastricht, the Netherlands, 2021

Cover design: Nicole Houben

Layout: Ivo Houben

Production: proefschriften.nl 


\section{Assessment of CEM: Towards a full-fledged clinical tool for breast cancer diagnosis and screening.}

\section{Proefschrift}

Ter verkrijging van de graad van doctor aan de Universiteit Maastricht, op het gezag van de Rector Magnificus prof. dr. R. Letschert volgens het besluit van het College van Decanen, in het openbaar te verdedigen op maandag 8 november 2021 om 16:00 uur

$$
\text { door }
$$

Ivo Petrus Louise Houben

Geboren 29 augustus 1992 te Maastricht 
Promotor:

Prof. Dr. J.E. Wildberger

Co-promotores:

Dr. M.B.I. Lobbes

Dr. U.C. Lalji

Beoordelingscommissie:

Prof. Dr. L. Boersma (Voorzitter)

Dr. S. Engelen

Prof. Dr. R. van der Hulst

Prof. Dr. R. Pijnappel

Prof. Dr. K. Van de Vijver 


\section{Table of contents}

$\begin{array}{lll}\text { Chapter } 1 & \text { Introduction } & 7\end{array}$

Chapter 2 Assessing the Risk of Contrast-Induced Nephropathy Using a Finger Stick Analysis in Recalls from Breast Screening: The CINFIBS Explorative Study. Contrast Media \& Molecular Imaging. September 2017, published.

Houben I.P.L., van Berlo C.J.L.Y. et al.

Chapter 3 Contrast-enhanced spectral mammography in recalls from the Dutch breast cancer screening program: Validation of results in a large multireader, multicase study. European Radiology. April 2016, published.

Lalji U.C., Houben I.P.L. et al.

Chapter 4 Contrast-enhanced spectral mammography as work-up tool in patients recalled from breast cancer screening has low risks and might hold clinical benefits. European Journal of Radiology. July 2017, published.

Houben I.P.1., van de Voorde P.V. et al.

Chapter 5

Contrast-enhanced spectral mammography in the evaluation 85 of breast suspicious calcifications: Diagnostic accuracy and impact on surgical management. Acta Radiologica.

January 2019, published.

Houben I.P.L., Vanwetswinkel S. et al.

Chapter 6 Rapid Access to Contrast-Enhanced spectral mammogRaphy in women recalled from breast cancer screening - the RACER trial study design. Trials.

December 2019, published.

Neeter L.M.F.H., Houben I.P.L. et al.

Chapter 7

Discussion

Impactparagraaf

Summary

Samenvatting

Dankwoord

Curriculum Vitae

177

List of Publications 

Chapter 1

\section{Introduction}





\section{Introduction}

Breast cancer is one of the leading causes of cancer-related deaths in women worldwide. ${ }^{1}$ In

the Netherlands, one out of seven women will suffer from breast cancer at some time in her life. $^{2}$

Although the incidence of breast cancer has increased since the 1990s, survival rates have steadily improved over the years. Figure 1 shows that the five-year survival rate of breast cancer patients was $78 \%$ in 1990 , while in 2016, the five-year survival rate was $88 \%{ }^{2}$ Although more advanced treatment options have played an important role in improving breast cancer survival, an equally important role has been played by breast cancer screening programmes and more accurate imaging modalities enabling earlier detection. In the Netherlands, since women started to participate in organized screening programmes, breast cancer mortality rate was reduced by $25 \%$ between 1997 and $2007 .^{3}$

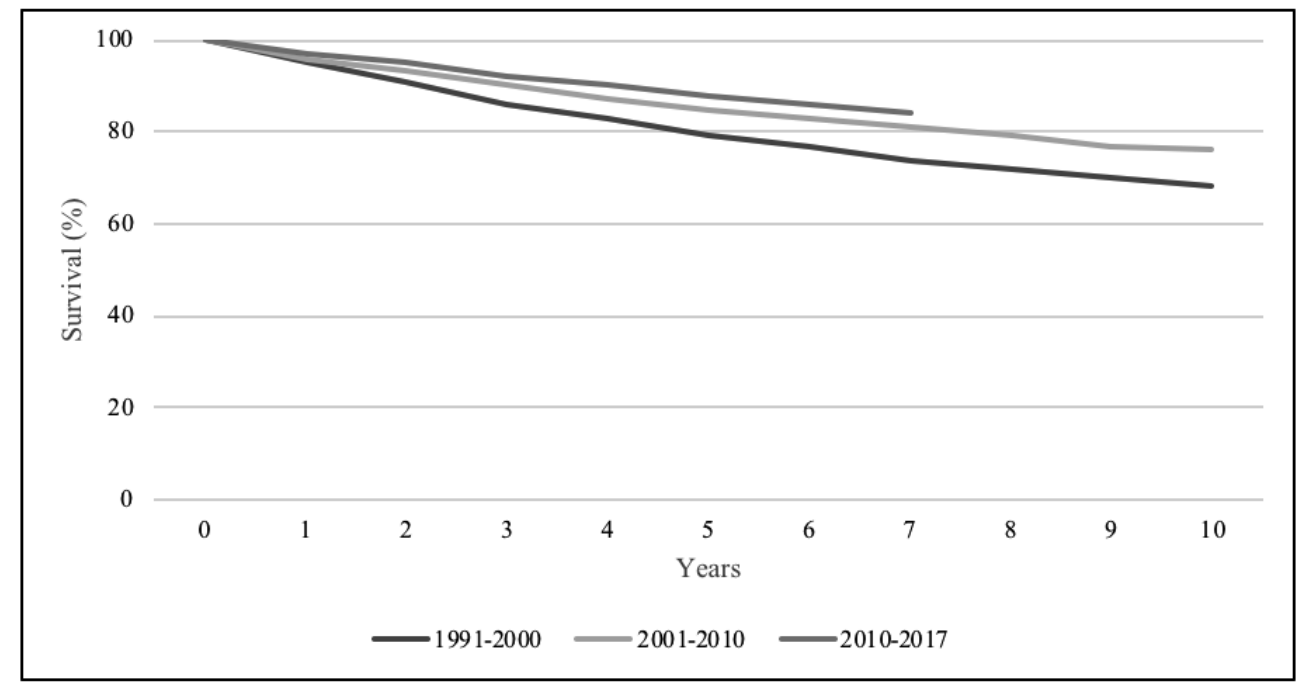

Figure 1. Increased survival rate of Dutch women diagnosed with breast cancer since $1990^{2}$; source: Integraal Kankercentrum Nederland (IKNL). 
In the Netherlands, breast cancer screening was initiated in 1989, and nation-wide roll-out was completed in 1996. Since then, all women aged between 50 and 70 years were invited to undergo mammography biannually. In 1998, the upper age limit was extended to 75 years. In $2018,976,032$ women were screened ( $76.6 \%$ of the invited). ${ }^{3}$ Approximately $2.2 \%$ of screened women are recalled for further investigation of a screen-detected breast lesion. ${ }^{2}$

Mammography plays an important role in the detection of breast cancer. Today, mammography is the only proven (screening) imaging modality to reduce breast cancer mortality. ${ }^{4}$ However, the diagnostic accuracy of mammography strongly depends on the density of fibroglandular tissue of the breast, with mammography of dense breast tissue being diagnostically less accurate. ${ }^{5}$ Novel techniques, such as digital breast tomosynthesis (DBT) or contrast-enhanced mammography (CEM), may provide solutions to increase accuracy (predominantly in dense breasts). ${ }^{6}$

Previous studies have shown that CEM is superior to full-field digital mammography (FFDM) for breast cancer detection ${ }^{4}$. It was also demonstrated that CEM was clinically feasible in a population with low disease prevalence, i.e. recalls from a breast cancer screening programme ${ }^{4}$. Although all diagnostic performance parameters in this study improved when using CEM, the most important changes were observed in specificity and positive predictive value (PPV). Specificity and PPV increased from $42 \%$ to $87.7 \%$ and $39.7 \%$ to $76.2 \%$, respectively. Hence, CEM might be an important problem-solving tool in women recalled for breast cancer screening.

When performing CEM, an iodine-based contrast agent needs to be administered intravenously. A total of $1.5 \mathrm{ml} / \mathrm{kg}$ contrast agent is administered at $2-3 \mathrm{ml} / \mathrm{s}$, preferably using an automated injector and followed by a saline flush. Two minutes after administration, the patient will be positioned at the mammograph by a trained technician and two subsequent images of each breast will be made per view (usually in the standard craniocaudal (CC) and mediolateral oblique (MLO) views, although special views can be requested in CEM mode as well). The first (low energy) image is similar to a conventional FFDM ${ }^{7-9}$ (Figure 2A) and is followed by a second (high energy) image that has no diagnostic utility (Figure 2B), but which is used for post-processing to create a so-called recombined image (Figure 2C). Between each view, breast compression is relieved. ${ }^{6} 10$ 

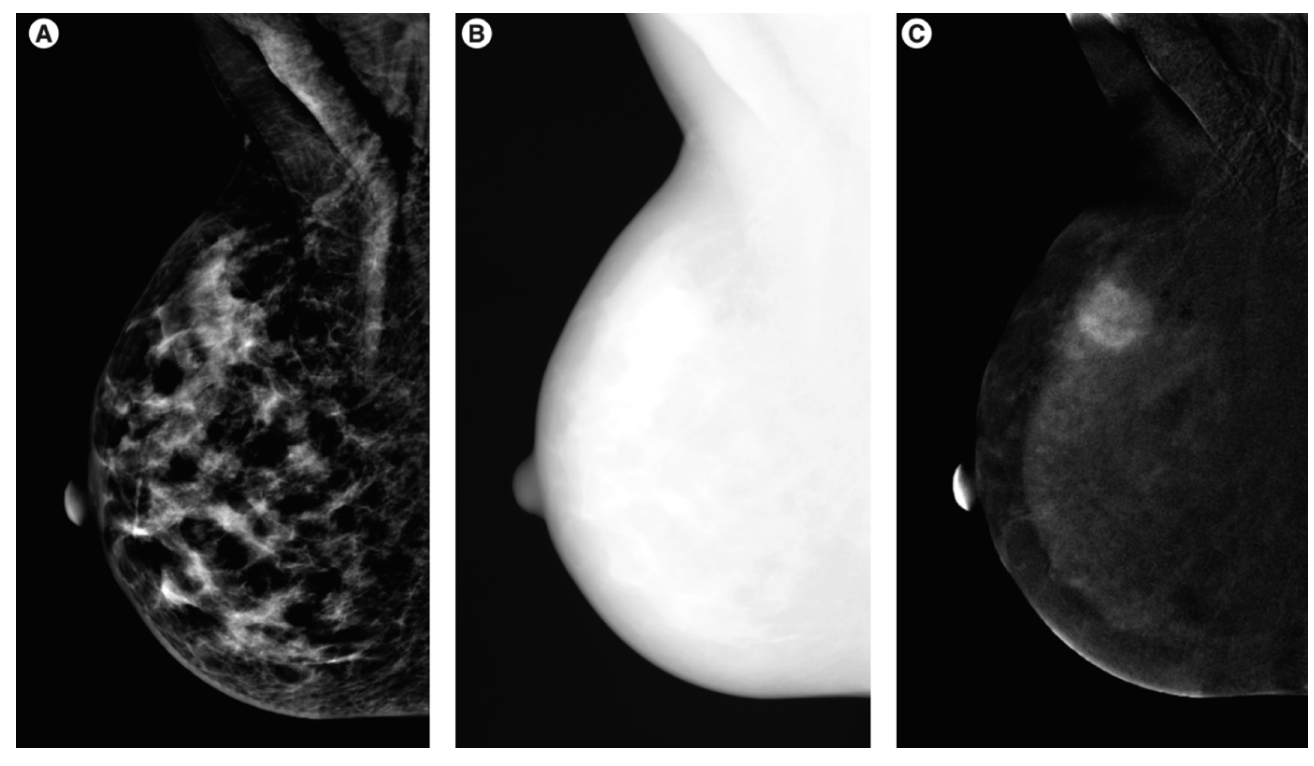

Figure 2. Image A shows a low energy image, comparable to an FFDM. Image B displays a high energy image that is used for post-processing purposes, only. Image $\mathrm{C}$ shows the recombined image, with an enhancing area, suspicious for a malignant lesion. ${ }^{11}$ 
When tumors are small, they rely on diffusion for their nutritional demand. When a tumor grows, diffusion becomes insufficient and vascular growth factors will be secreted, drawing newly formed vessels towards the tumor. Due to the rapid formation of these vessels, they tend to be 'leaky'. As a result, the administered contrast agent can leak into the interstitium of the tumour, causing enhancement (i.e. capitation of iodine) that is visible on the recombined images of CEM. ${ }^{12}$

Since the commercial availability of CEM in 2011, several studies have indicated that CEM is an excellent tool for the imaging workup of patients recalled from a national breast cancer screening programme ${ }^{1013}$.

Several studies published by our research group focused on the implementation of CEM in daily clinical practice. These studies showed promising initial performances of CEM in patients who were recalled from breast cancer screening. Our group showed that CEM is comparable to FFDM in image quality, and it is equally accurate as breast MRI in determining the extent of disease and has a steep learning curve, especially in non-experienced users. 10111314 The current thesis is a continuation of this ongoing evaluation, namely the implementation of CEM in the daily clinical practice. This thesis focused on the applicability of CEM and the consequences of possible encountered disadvantages and pitfalls.

In chapter 2, the implementation of CEM in daily clinical practice was evaluated with respect to a patient's risk of developing contrast-induced nephropathy. In general, the glomerular filtration rate should be determined before a CEM exam, which could hamper rapid access to CEM. We investigated whether a point-of-care analysis (i.e., finger-prick blood sample, enabling us to assess the glomerular filtration rate in seconds) was able to identify patients at risk of developing contrast-induced nephropathy.

In chapter 3, the promising results of an earlier interim study evaluated by a panel of ten radiologists with different levels of (CEM) experience were reevaluated using 199 novel CEM cases to investigate whether the diagnostic accuracy of CEM would be consistent in a larger number of investigators.

In chapter 4, we studied and compared the advantages and disadvantages of CEM, i.e. radiation dose, contrast administration, unnecessary biopsies due to misinterpreted lesions on FFDM and its diagnostic accuracy. 
In chapter 5, the diagnostic performance of CEM in suspicious calcifications was studied. The impact of CEM on the detection of suspicious calcifications was evaluated. We also studied its ability to assess the extent of disease and its impact on surgical outcome.

In chapter 6, we presented the design of a randomized controlled clinical trial for women that are recalled from breast cancer screening. This prospective multicenter study randomizes all women recalled into two groups: one receiving standard care (i.e., conventional breast imaging, such as FFDM, DBT and/or ultrasound) and the other receiving rapid access to a CEM examination.

Finally, the results and conclusions of the abovementioned studies were discussed in chapter 7. 


\section{References}

1. Ferlay J, Soerjomataram I, Dikshit R, et al. Cancer incidence and mortality worldwide: sources, methods and major patterns in GLOBOCAN 2012. Int $J$ Cancer 2015;136(5):E359-86. doi: 10.1002/ijc.29210 [published Online First: 2014/09/16]

2. Incidence of breast cancer in dutch population. Integraal kankercentrum nederland: IKNL; 2018

[Available

from:

http://www.cijfersoverkanker.nl/selecties/Incidentie borstkanker2020.

3. Monitoring the national breast cancer screening programme Rijksinstituut voor Volksgezondheid en milieu (RIVM); 2018 [Available from: www.rivm.nl/documenten/monitor-bevolkingsonderzoek-borstkanker-2017-2018.

4. Verbeek AL, Broeders MJ, Otto SJ, et al. [Effects of the population screening into breast cancer]. Ned Tijdschr Geneeskd 2013;157(10):A5218. [published Online First: 2013/03/08]

5. Carney PA, Miglioretti DL, Yankaskas BC, et al. Individual and combined effects of age, breast density, and hormone replacement therapy use on the accuracy of screening mammography. Ann Intern Med 2003;138(3):168-75. doi: 10.7326/0003-4819-138-3200302040-00008 [published Online First: 2003/02/01]

6. Lobbes MB, Smidt ML, Houwers J, et al. Contrast enhanced mammography: techniques, current results, and potential indications. Clin Radiol 2013;68(9):935-44. doi: 10.1016/j.crad.2013.04.009 [published Online First: 2013/06/25]

7. Fallenberg EM, Dromain C, Diekmann F, et al. Contrast-enhanced spectral mammography: Does mammography provide additional clinical benefits or can some radiation exposure be avoided? Breast Cancer Res Treat 2014;146(2):371-81. doi: 10.1007/s10549-0143023-6 [published Online First: 2014/07/06]

8. Francescone MA, Jochelson MS, Dershaw DD, et al. Low energy mammogram obtained in contrast-enhanced digital mammography (CEDM) is comparable to routine full-field digital mammography (FFDM). Eur $J$ Radiol 2014;83(8):1350-5. doi: 10.1016/j.ejrad.2014.05.015 [published Online First: 2014/06/17]

9. Lalji UC, Jeukens CR, Houben I, et al. Evaluation of low-energy contrast-enhanced spectral mammography images by comparing them to full-field digital mammography using EUREF image quality criteria. Eur Radiol 2015;25(10):2813-20. doi: 10.1007/s00330015-3695-2 [published Online First: 2015/03/31] 
10. Lobbes MB, Lalji U, Houwers J, et al. Contrast-enhanced spectral mammography in patients referred from the breast cancer screening programme. Eur Radiol 2014;24(7):1668-76. doi: 10.1007/s00330-014-3154-5 [published Online First: 2014/04/04]

11. Lalji U, Lobbes M. Contrast-enhanced dual-energy mammography: a promising new imaging tool in breast cancer detection. Womens Health (Lond) 2014;10(3):289-98. doi: 10.2217/whe.14.18 [published Online First: 2014/06/24]

12. Hashizume H, Baluk P, Morikawa S, et al. Openings between defective endothelial cells explain tumor vessel leakiness. Am J Pathol 2000;156(4):1363-80. doi: 10.1016/S00029440(10)65006-7 [published Online First: 2000/04/07]

13. Lalji UC, Houben IP, Prevos R, et al. Contrast-enhanced spectral mammography in recalls from the Dutch breast cancer screening program: validation of results in a large multireader, multicase study. Eur Radiol 2016;26(12):4371-79. doi: 10.1007/s00330016-4336-0 [published Online First: 2016/04/22]

14. Lobbes MB, Lalji UC, Nelemans PJ, et al. The quality of tumor size assessment by contrastenhanced spectral mammography and the benefit of additional breast MRI. J Cancer 2015;6(2):144-50. doi: 10.7150/jca.10705 [published Online First: 2015/01/07] 



\section{Chapter 2}

Assessing the Risk of Contrast-Induced Nephropathy Using a Finger Stick Analysis in Recalls from Breast Screening: The CINFIBS Explorative Study

I.P.L. Houben, C.J.L.Y. van Berlo, O. Bekers, E. Nijssen, M.B.I. Lobbes,

J.E. Wildberger

Contrast Media \& Molecular Imaging, 2017. 5670384. 



\section{Abstract}

Purpose - To evaluate whether a handheld point-of-care (POC) device is able to predict and discriminate patients at potential risk of CIN prior to iodine-based contrast media delivery.

Methods and Materials - Between December 2014 and June 2016, women undergoing CEM with an iodine-based contrast agent were asked to have their risk of CIN assessed by a dedicated POC device (StatSensor CREAT) and a risk factor questionnaire based on national guidelines. Administration of contrast was decided based on these results. Prior to contrast injection, a venous blood sample was drawn to compare the results of POC with regular laboratory testing. In cases when finally CIN was suspected, additional renal clearance was assessed after 2-5 and 30 days.

Results - A total of 351 patients were included, of which 344 were finally categorized as low risk patients by blood creatinine evaluation. Seven patients had an eGFR below 60 $\mathrm{ml} / \mathrm{min} / 1.73 \mathrm{~m}^{2}$, necessitating additional preparation prior to contrast delivery according to the current guidelines. One patient in the potential risk group was correctly identified by the POC device, only. The POC device failed to categorize six out of seven patients (86\%), leading to (at that stage) unwanted contrast administration. Two patients subsequently developed CIN after 2-5 days, which was self-limiting after 30 days.

Conclusion - The POC device tested was not able to reliably assess impairment of renal function in our patient cohort undergoing CEM. Consequently, we still consider classic clinical laboratory testing preferable in patients at potential risk for developing CIN. 


\section{Introduction}

In the Netherlands, all women aged between 50-75 years are invited biennially for screening mammography. When suspect lesions are found, women are recalled to a hospital of their choice for further diagnostic testing. CEM has been shown to be a reliable problem-solving tool in these recalled women, as it diagnoses breast cancer accurately, while ruling out breast cancer confidently ${ }^{12}$. In addition, studies have shown that the quality of a (low-energy) CEM image is like a FFDM, thus omitting the necessity of performing a FFDM when a direction indication for CEM exists ${ }^{34}$. Since CEM uses an intravenous administration of an iodine based contrast agent, new logistical challenges must be solved. ${ }^{5}$

Hence, patients with risk factors such as advanced age, diabetes or heart failure, are screened by questionnaires beforehand to discriminate whether prophylactic measures should be considered prior to the exam itself.

In general, it takes one to several hours for clinical laboratory tests of renal function to become available, which will delay diagnostic testing by several hours or even by a working day. This makes the use of POC systems attractive from a workflow perspective.

Therefore, the aim of this study is to test the clinical applicability of a rapid finger stick analysis to determine renal function prior to iodinated contrast agent administration within several seconds, as opposed to hours required for a classic laboratory determination. 


\section{Materials and methods}

Women eligible for CEM in the period December 2014 to June 2016 were asked to voluntarily participate in this observational study. Exclusion criteria were known allergies for iodine-based contrast agents or contra-indications to undergo CEM (such as breast implants). The local ethical committee waived the requirement for formal written informed consent (decision number METC 14-4-168).

Based on the guidelines provided by our national safety program ('VMS Veiligheidsprogramma') the following data regarding risk factors for CIN were collected via a questionnaire $^{6}$ : type 2-diabetes, Kahler's disease, Waldenström's disease, peripheral artery disease, heart failure, anemia, hypotension, dehydration and nephrotoxic medication. To assess serum creatinine levels and estimated glomerular filtration rate (eGFR), a point of care (POC) finger stick measurement (StatSensor CREAT, Nova Biomedical Corporation, Waltham, MA, USA) was performed according to the instruction manual. In short, the POC-device was prepared by inserting age, race, and sex into the device, followed by the insertion of a blood sampling strip (StatStick, Nova Biomedical). Using a small finger prick, a capillary blood sample was applied onto the strip, which triggered the automated analysis of both the serum creatinine level and calculation of the eGFR. The time needed for the analysis of eGFR and creatinine level by the device was measured.

Next, an intravenous $22 \mathrm{G}$ catheter was placed in the left/right antecubital vein and venous blood samples were drawn within 15 minutes of the POC measurement using a vacuum system (Vacutainer, Becton, Dickinson and Company Europe, Eysins, Switzerland) and used for the clinical laboratory testing, was collected in a tube (with clot activator and gel for serum separation as additive) (Vacutainer with Hemoguard Gold, Becton).

After venous blood sampling, automated contrast injection (Ultravist 300, Bayer Healthcare, Berlin, Germany) was performed as part of the CEM exam (dose $1.5 \mathrm{~mL} / \mathrm{kg}$ body weight, flow rate $3 \mathrm{~mL} / \mathrm{s})$.

Serum creatinine were assessed using the enzymatic method (Cobas 8000; Roche Diagnostics, Rotkreuz, Switzerland). The eGFR has been calculated following the IDMS (Isotope Dilution Mass Spectrometry) - traceable MDRD (Modification of Diet in Renal Disease) study. ${ }^{7} \mathrm{We}$ were not able to monitor the exact analytical time for the laboratory measurements, since these are collected in the central laboratory department and tested in batches. 
Also, taking blood samples to a central laboratory facility results in transportation time, which is undoubtedly much slower than a rapid POC-analysis.

Based on the different test results, patients were categorized as low or potential risk for developing CIN. The results of the POC measurements were used to determine if contrast administration was regarded as safe at this moment. The results of the laboratory served as the reference standard in our evaluation of the POC measurement. When the laboratory results categorized a patient as potential risk afterwards, additional blood analyses were performed after 2-5 days and after 30 days to check for clinical signs of CIN.

\section{Statistical analysis}

For this study, descriptive statistics were used. The mean analytical time of the POC, including its standard deviation was calculated. All analyses were performed using SPSS (IBM SPSS Statistics; version 23. IBM Corporation, Armonk, NY, USA). 


\section{Results}

In the study period, 365 patients were recalled from the breast cancer screening program and volunteered for study participation. All 365 patients gave informed consent and participated in this study.

14 patients had to be excluded due to the inability to withdraw venous blood through the vacuum system used.

Of the 351 included patients, 350 patients $(99.7 \%)$ were categorized as low risk based on the questionnaire and POC measurement. In contrast, 344 patients (98.0\%) were determined as low risk by the laboratory results. In this latter group, all patients were correctly indicated as being low risk by the POC measurement. Seven patients were determined as potential risk by the laboratory results. Of these, three patients had an eGFR $<45 \mathrm{ml} / \mathrm{min} / 1.73 \mathrm{~m}^{2}$, whereas four patients had an eGFR $<60 \mathrm{ml} / \mathrm{min} / 1.73 \mathrm{~m}^{2}$ with more than two risk factors. The POC-device correctly identified one patient as potential risk for CIN, only (Figure 1). 


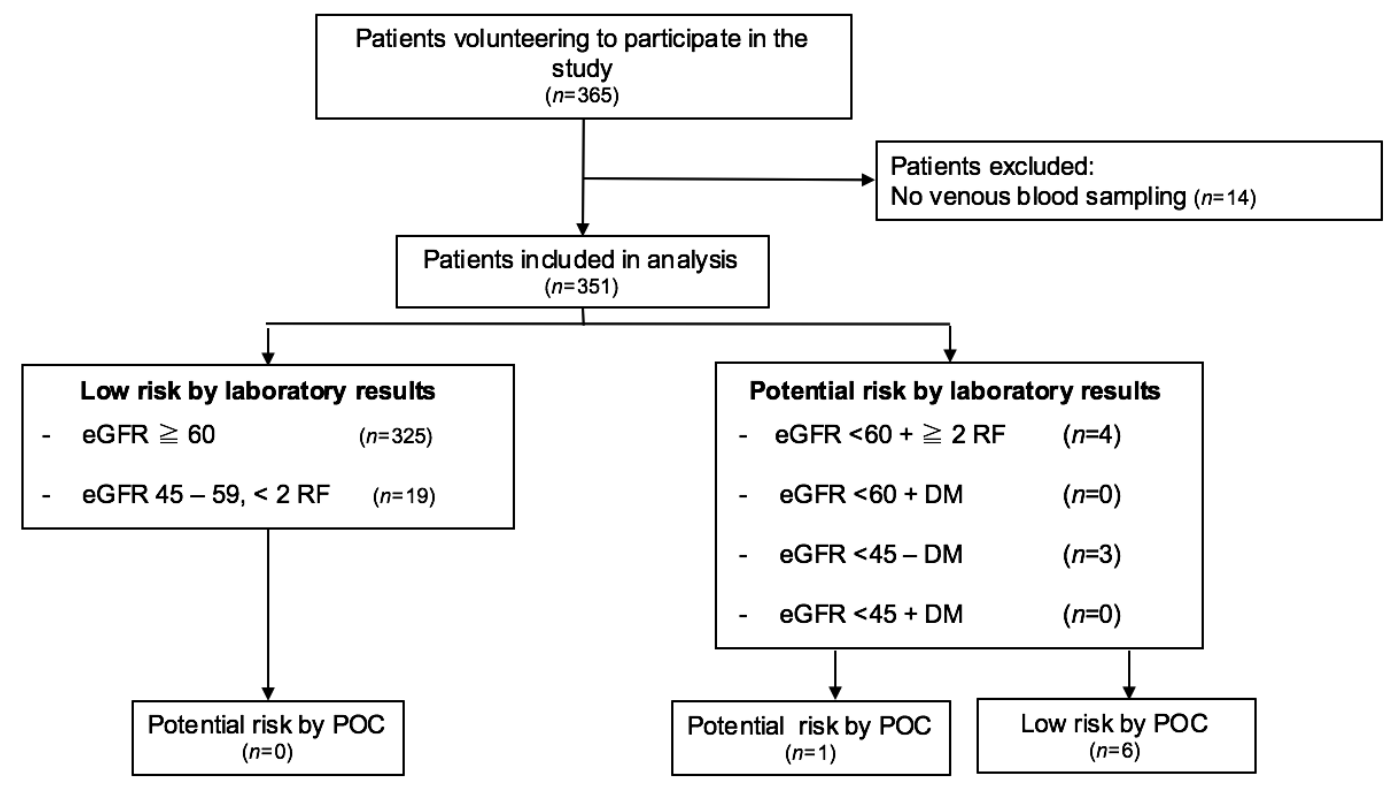

Figure 1. Flowchart of patient inclusion and final risk assessment categories for both the laboratory as the point-of-care (POC) measurements. Other abbreviations are: estimated glomerular filtrations rate (eGFR), risk factor (RF), and diabetes mellitus (DM).

The POC-device determined a creatinine level of $55 \mathrm{ml} / \mathrm{min} / 1.73 \mathrm{~m}^{2}$, the patient had five additional clinical risk factors (age, heart failure, anemia, hypotension and nephrotoxic medication). Despite this information, the radiologist on call decided (after consulting the referring physician) to continue with CEM nonetheless, since prehydration in this patient suffering from heart failure was expected to cause even more harm. In addition, she underwent contrast-enhanced imaging exams before using iodine-based contrast agents with no adverse effects on her renal function. Her eGFR prior to CEM was $46 \mathrm{ml} / \mathrm{min} / 1.73 \mathrm{~m}^{2}$ (laboratory results) and $49 \mathrm{ml} / \mathrm{min} / 1.73 \mathrm{~m}^{2}$ after 5 days. Table 1 presents a case-by-case description of the patients that were at potential risk of developing CIN according to the laboratory results.

In contrast, six patients were indicated as low risk by the POC measurement, although the laboratory measurements in combination with various risk factors classified these patients as potential risk. Hence, these patients incorrectly received contrast agent based to the POC measurements and were subsequently recalled for an additional blood sampling. CIN was diagnosed in two patients, with renal function normalization after 30 days. 
The mean analytical time was for a POC measurement was 47.8 seconds (SD 5.1 seconds), which is without doubt much faster than any clinical laboratory testing.

\begin{tabular}{|l|c|c|c|c|c|c|c|c|c|c|c|c|c|l|}
\hline Patient & Age (yr) & $\begin{array}{c}\text { GGFR } \\
\text { POC }\end{array}$ & $\begin{array}{c}\text { eGFR } \\
\text { LAB }\end{array}$ & DM & Kahler & Waldenström & PAD & HF & Anemia & HT & DH & Med & CIN & Pathology \\
\hline 1 & 57 & 47 & 43 & No & No & No & No & No & No & No & No & No & No & Ductectasia \\
\hline 2 & 57 & 60 & 40 & No & No & No & Yes & Yes & No & No & No & No & Yes & $\begin{array}{l}\text { Apocrine } \\
\text { changes }\end{array}$ \\
\hline 3 & 69 & 63 & 59 & No & No & No & No & No & No & Yes & No & Yes & No & IDC \\
\hline 4 & 74 & 55 & 46 & No & No & No & No & Yes & Yes & Yes & No & Yes & No & $\begin{array}{l}\text { Benign } \\
\text { n.o.s. }\end{array}$ \\
\hline 5 & 65 & 78 & 52 & No & No & No & No & No & No & Yes & No & Yes & No & Cyst \\
\hline 6 & 73 & 90 & 58 & No & No & No & No & No & No & Yes & No & Yes & Yes & Ductectasia \\
\hline 7 & 71 & 60 & 37 & No & No & No & No & No & No & No & No & No & No & Cyst \\
\hline
\end{tabular}

Table 1. Detailed characteristics of the patients at high risk for developing CIN. Other abbreviations are: estimated glomerular filtration rate (eGFR), point-of-care measurement (POC), clinical laboratory measurement (LAB), diabetes mellitus type II (DM), peripheral artery disease (PAD), heart failure (HF), hypotension (HT), dehydration (DH), nephrotoxic medication (Med), invasive ductal carcinoma (IDC), and not otherwise specified (nos). Unit of eGFR measurement: $\mathrm{ml} / \mathrm{min} / 1.73 \mathrm{~m}^{2}$. Patient \#4 was the only correctly identified high risk patient as determined by the POC handheld device. 


\section{Discussion}

CIN is an important side-effect of the administration of iodine-based contrast agents, with a reported incidence from 1 to $30 \%$, depending on the population studied. ${ }^{7}$ In the assessment of risk of developing $\mathrm{CIN}$, measurement of renal function (i.e. serum creatinine levels) plays a pivotal role. However, measurement of serum creatinine levels in clinical laboratories takes often a minimum of one hour to perform, which is unwanted in scenarios where speedy diagnostics are preferred.

In this study, we aimed to test the clinical applicability of a rapid finger stick analysis to determine renal function prior to iodinated contrast agent administration in exams which are logistically challenging, such as CEM on an outpatient basis.

For this purpose, rapid POC measurements are available that can assess renal function within a much shorter time frame (mean time in our study 48 seconds). These usually consist of handheld devices in which in applicator strip is inserted which can analyze a small drop of blood acquired through a small finger prick. Lomakin et al. recently reviewed a larger number of currently available POC devices and concluded that these in general suffered from a moderate concordance when compared to standardized renal function measurements. ${ }^{8}$ To be more specific: these devices have a small mean difference in measurements when compared to standard methods, but their $95 \%$ limits of agreement often lay between -35.4 and $35.4 \mu \mathrm{mol} / \mathrm{L}$, sometimes even exceeding $88.4 \mu \mathrm{mol} / \mathrm{L}$. This could lead to an important number of falsenegative results by POC measurements, exposing patients to iodine-based contrast agents when they are at potential risk of developing CIN. However, the findings of Lomakin et al. are difficult to translate to the clinical setting, since multiple devices were used in the different studies, which also differed in populations studied and reference standards used.

In our study, most patients were at low risk for developing CIN and correctly identified by POC measurements. However, the smaller number of patients who were at potential risk for developing CIN could not be identified by using the POC measurement: only one out of seven potential risk patients was correctly identified. One patient might be regarded as borderline normal with an eGFR of $59 \mathrm{ml} / \mathrm{min} / 1.73 \mathrm{~m}^{2}$ and a POC value of $63 \mathrm{ml} / \mathrm{min} / 1.73 \mathrm{~m}^{2}$, which is within the error limit of any diagnostic test. However, the other five patients must be regarded as a knock-out for the clinical applicability of the device tested. These patients incorrectly received contrast administration, of which two developed CIN after several days. CIN was selflimiting in all patients within 30 days. 
Thus, when performing CEM in daily practice, the clinical pathway will have to follow the current questionnaire assessment. If triggers for CIN are found, an intravenous blood sample will have to be drawn, regardless of the time needed for analysis, to allow for adequate risk assessment for CIN prior to contrast material delivery.

Of note, the clinical impact of CIN is still under debate. A recent retrospective study of postcontrast acute kidney injury after CT exams showed that the odds ratio for developing acute kidney injury starts to increase from eGRF levels of $30-44 \mathrm{ml} / \mathrm{min} / 1.73 \mathrm{~m}^{2}$, with the highest odds ratio (OR 2.96) in patients with eGFR $<30 \mathrm{ml} / \mathrm{min} / 1.73 \mathrm{~m}^{2}$. In contrast, a similar study by McDonald et al. found no such increased risk in this latter patient category. ${ }^{9-11}$ Since CIN cannot be treated, many studies and national guidelines have focused on its prevention, most commonly by using prehydration protocols for patients at risk for CIN. In this regard, it was recently shown that refraining from prehydration is non-inferior and cost-saving in preventing CIN compared with preventive prehydration. ${ }^{12}$ The current study, however, was based on current national guidelines and focused on finding a new (POC-based) strategy to deal with logistical challenges caused by these guidelines.

Whether the most recent insights are a cause to re-evaluate the currently existing national guidelines regarding the prevention of CIN is beyond the scope of this paper.

Our study has some limitations. First, we only included patients scheduled to undergo CEM for a screen-recalled breast lesion. In our country, these are women between 50-75 years with a low prevalence of risk factors for developing CIN. In previous studies, the concordances between the POC measurements and the reference standard decreased with increased serum creatinine levels. ${ }^{8}$ This might further limit the utility of these devices in patients with a higher chance of developing CIN, i.e. patients with more risk factors, such as cardiac patients or patients from an intensive care unit. Hence, even though the population studied was a specific one, it contained patients with the most favorable profiles for the best performance of the POC device. Second, only women recalled from screening that underwent CEM were asked to participate in this observational study. We think they are quite representative for the general population of a breast imaging department, i.e. women over 50 years of age, the majority being postmenopausal. Also, we tested only a single POC device. Thus, one should interpret our observations with these limitations in mind. 
In summary, the clinical use of POC systems is attractive, especially considering workflow logistics. From a patient safety perspective, however, the handheld POC device tested (StatSensor CREAT) was not able to reliably assess impairment of renal function in our patient cohort undergoing CEM. Consequently, we consider classic clinical laboratory testing preferable in patients at potential risk for developing CIN. 


\section{References}

1. Lobbes MB, Lalji U, Houwers J, et al. Contrast-enhanced spectral mammography in patients referred from the breast cancer screening programme. Eur Radiol 2014;24(7):1668-76. doi: 10.1007/s00330-014-3154-5 [published Online First: 2014/04/04]

2. Lalji UC, Houben IP, Prevos R, et al. Contrast-enhanced spectral mammography in recalls from the Dutch breast cancer screening program: validation of results in a large multireader, multicase study. Eur Radiol 2016;26(12):4371-79. doi: 10.1007/s00330016-4336-0 [published Online First: 2016/04/22]

3. Fallenberg EM, Dromain C, Diekmann F, et al. Contrast-enhanced spectral mammography: Does mammography provide additional clinical benefits or can some radiation exposure be avoided? Breast Cancer Res Treat 2014;146(2):371-81. doi: 10.1007/s10549-0143023-6 [published Online First: 2014/07/06]

4. Lalji UC, Jeukens CR, Houben I, et al. Evaluation of low-energy contrast-enhanced spectral mammography images by comparing them to full-field digital mammography using EUREF image quality criteria. Eur Radiol 2015;25(10):2813-20. doi: 10.1007/s00330015-3695-2 [published Online First: 2015/03/31]

5. Lobbes MB, Smidt ML, Houwers J, et al. Contrast enhanced mammography: techniques, current results, and potential indications. Clin Radiol 2013;68(9):935-44. doi: 10.1016/j.crad.2013.04.009 [published Online First: 2013/06/25]

6. Veiligheidsmanagementsysteem (VMS). VMS Veiligheidsprogramma, praktijkgids 'Nierinsufficientie': VMS zorg; 2016 [updated October 2016. Available from: www.vmszorg.nl/_library/5541/web_2009.0105_praktijkgids_nierinsufficientie.pdf.

7. Levey AS, Coresh J, Greene T, et al. Using standardized serum creatinine values in the modification of diet in renal disease study equation for estimating glomerular filtration rate. Ann Intern Med 2006;145(4):247-54. doi: 10.7326/0003-4819-145-4-20060815000004 [published Online First: 2006/08/16]

8. Martinez Lomakin F, Tobar C. Accuracy of point-of-care serum creatinine devices for detecting patients at risk of contrast-induced nephropathy: a critical overview. Crit Rev Clin Lab Sci 2014;51(6):332-43. doi: 10.3109/10408363.2014.937794 [published Online First: 2014/07/19] 
9. McDonald RJ, McDonald JS, Newhouse JH, et al. Controversies in Contrast Materialinduced Acute Kidney Injury: Closing in on the Truth? Radiology 2015;277(3):627-32. doi: 10.1148/radiol.2015151486 [published Online First: 2015/11/26]

10. Davenport MS, Khalatbari S, Cohan RH, et al. Contrast material-induced nephrotoxicity and intravenous low-osmolality iodinated contrast material: risk stratification by using estimated glomerular filtration rate. Radiology 2013;268(3):719-28. doi: 10.1148/radiol.13122276 [published Online First: 2013/04/13]

11. McDonald JS, McDonald RJ, Carter RE, et al. Risk of intravenous contrast materialmediated acute kidney injury: a propensity score-matched study stratified by baselineestimated glomerular filtration rate. Radiology 2014;271(1):65-73. doi: 10.1148/radiol.13130775 [published Online First: 2014/01/31]

12. Nijssen EC, Rennenberg RJ, Nelemans PJ, et al. Prophylactic hydration to protect renal function from intravascular iodinated contrast material in patients at high risk of contrast-induced nephropathy (AMACING): a prospective, randomised, phase 3, controlled, open-label, non-inferiority trial. Lancet 2017;389(10076):1312-22. doi: 10.1016/S0140-6736(17)30057-0 [published Online First: 2017/02/25] 




\section{Chapter 3}

Contrast-enhanced spectral mammography in recalls from the Dutch breast cancer screening program: validation of results in a large multireader, multicase study.

U.C. Lalji, I.P.L. Houben, R. Prevos, S. Gommers, M. van Goethem, S. Vanwetswinkel, R. Pijnappel, R. Steeman, C. Frotscher, W. Mok, P.J. Nelemans, M.L. Smidt, R.G. Beets-Tan, J.E. Wildberger, M.B.I. Lobbes

European Radiology. 2017, 26(12), 4371-4379 



\section{Abstract}

Objective - CEM is a promising problem-solving tool in women referred from the breast cancer screening program. We aimed to study the validity of preliminary results of CEM using a larger panel of radiologists with different levels of CEM experience.

Material and methods - All women referred from the Dutch breast cancer screening program were eligible for CEM. 199 consecutive cases were viewed by ten radiologists. Four had extensive CEM experience, three had no CEM experience but were experienced breast radiologists, and three were residents. All readers provided a BI-RADS score for the low-energy CEM images first, after which the score could be adjusted when viewing the entire CEM exam. BI-RADS 1-3 were considered benign and BI-RADS 4-5 malignant. With this cut off, we calculated sensitivity, specificity and area under the ROC curve.

Results - CEM increased diagnostic accuracy in all readers. The performance for all readers using CEM was: sensitivity $96.9 \%(+3.9 \%)$, specificity $69.7 \%(+33.8 \%)$ and area under the ROC curve $0.833(+0.188)$.

Conclusion - CEM is superior to conventional mammography with excellent problem-solving capabilities in women referred from the breast cancer screening program. Previous results were confirmed even in a larger panel of readers with varying CEM experience. 


\section{Introduction}

In breast imaging, mammography plays a pivotal role in breast cancer detection and evaluation. Although the diagnostic accuracy of conventional mammography has improved significantly during the last decade due to the introduction of FFDM, its accuracy remains dependent on the density of the fibro glandular tissue. ${ }^{1}$ Several new mammographic techniques have been introduced to improve FFDM's diagnostic accuracy, the most recent one being CEM.

Previous studies have shown that CEM is superior to FFDM for breast cancer detection, even equaling the performance of breast MRI. ${ }^{2-4}$ It was also demonstrated that CEM was clinically feasible even in a study population with a low disease prevalence, i.e. recalls from a breast cancer screening program. ${ }^{5}$ Although all diagnostic performance parameters in this study improved when using CEM, the most important changes were observed regarding specificity (increasing from $42 \%$ to $87.7 \%$ ) and PPV, increasing from $39.7 \%$ to $76.2 \%$. These results showed that in this population CEM has great potential as a problem-solving tool. However, they were based on an interim analysis of the institution's first 113 patients and readings were performed by only two radiologists that were experienced in reading CEM exams. Reproducibility of initial findings is an important step in the evaluation of every new diagnostic technique. Therefore, we aimed to compare the diagnostic performance of FFDM and CEM using a larger panel of radiologists with different levels of CEM experience. ${ }^{5}$ 


\section{Materials and methods}

\section{Patient selection}

For this retrospective study, the requirement for obtaining informed consent was waived by the local ethics committee. All women recalled from the breast cancer screening program who were referred to our institution for assessment in the period November 2012 until October 2013 were eligible to undergo CEM. Women with a known allergy for iodinated contrast agents and those who had an increased risk for developing contrast induced nephropathy were excluded. The latter was established using the ESUR guidelines on Contrast Media as stated by the European Society of Urogenital Radiology (ESUR). ${ }^{6}$

\section{Imaging protocol and analysis}

The principle of the CEM technique was described elsewhere. ${ }^{7}$ In short, a low energy (LE) and a high-energy image (HE) is obtained of both breasts in the standard MLO and CC views. The LE images provide maximal soft tissue contrast and are similar to a conventional mammogram. ${ }^{8-10}$ The HE image is not of diagnostic quality and is used for post-processing purposes only. Both images are used to create a recombined image which shows enhancement of lesions. ${ }^{7}$ All CEM exams were performed on a single CEM unit (Senographe* Essential with Senobright* upgrade, GE Healthcare, Chalfont St Giles, United Kingdom) using a non-ionic monomeric low-osmolar contrast agent at a dose of $1.5 \mathrm{~mL} / \mathrm{kg}$ body weight (iopromide, Ultravist ${ }^{\circledR}$ 300, Bayer Healthcare, Berlin, Germany). Iodinated contrast was intravenously administered with a flow rate of $3 \mathrm{~mL} / \mathrm{s}$ two minutes prior to image acquisition. Both breasts were imaged in MLO and CC views with additional views to be requested by the radiologist if deemed necessary at the time of the exam. Patients were monitored for a minimal period of 30 minutes afterwards to rule out late adverse contrast reactions. The panel of readers consisted of seven dedicated breast radiologists and three residents. Of the dedicated breast radiologists, four had two years' experience with CEM (the experienced CEM users). Their range of experience with conventional mammography was 2-6 years. The remaining three dedicated breast radiologists had between 3-25 years of experience with mammography but no previous experience whatsoever regarding CEM. The residents had limited CEM and mammography experience (eight weeks' full time as part of their residency) and were trained in that period by 
the experienced CEM radiologists. The panel of readers were allowed to learn the reason of referral from the screening program (similar to everyday clinical practice) and started by evaluating the LE image first. An initial BI-RADS score of 1 to 5 had to be provided before evaluating the entire CEM exam, including both the LE and recombined images, during the same reading session. The reader was then allowed to upgrade or downgrade their BI-RADS score if deemed necessary. All radiologists were blinded for each other's scores, previous or follow up examinations and final diagnosis. Readers were divided into 3 subgroups: experienced CEM readers, inexperienced CEM readers and resident readers.

\section{Standard reference procedures used to assess true disease status}

To assess the true disease status of a recalled patient, one of the strategies below was followed. ${ }^{11}$ In case of suspicious calcifications or masses a biopsy was performed under ultrasound guidance or stereotactic guidance with histology serving as gold standard. In all cases of cysts, a targeted ultrasound examination was performed in combination with aspiration of the cyst to prove its non-solid nature. In cases where superposition of normal fibroglandular tissue was suspected, at least one additional view of the breast containing the suspicious lesion followed by targeted ultrasound was performed. If no abnormality was found on additional imaging, women were discharged according to the NHS Breast Screening Program (NHSBSP) Clinical Guidelines for Breast Cancer Screening Assessment and our national guidelines. ${ }^{12} 13$

\section{Statistical analysis}

BI-RADS scores 1-3 were considered benign and BI-RADS 4-5 malignant. Using this cut-off values sensitivity, specificity, PPV and NPV of the readers were calculated. Interpretation of images from the same set of patients by multiple readers are likely to be correlated. Moreover, because FFDM and CEM were performed in the same study population, the results of both tests are also correlated. Ignoring correlation can lead to misleadingly small estimates of the standard error and consequently too small $95 \%$ confidence intervals which are too small. To adjust for the correlated data structure, variance of the sensitivity and specificity for all readers and for subgroups of readers (experienced in CEM reading, non-experienced in CEM reading and residents) were adjusted with the variance inflation factor (VIF). 
The variance of the difference in sensitivity and specificity between FFDM and CEM was estimated based on these adjusted variances and the covariance between FFDM and CEM results. Adjusted 95\% confidence intervals (CI) were derived using an excel spreadsheet provided by Genders et al.. ${ }^{14}$

Receiver operating characteristic (ROC) curves were constructed for both imaging modalities and areas under the curve (AUC) with corresponding 95\% CI were calculated using bootstrap analyses (2,000 repetitions).

The DeLong test was used for paired comparison of the AUC of FFDM and CEM. ${ }^{15}$ Fleiss' generalized kappa coefficient was used to determine the interrater reliability for the image analysis of both FFDM and CEM. In a separate analysis, false negative and false positive findings were further evaluated. All false negatives were analyzed to identify potential CEM pitfalls. For false positives findings, cases were included for this sub analysis if five or more readers (i.e. more than half of the reading panel) scored this case as being false positive on CEM. All statistical analyses were performed using SPSS (IBM Corp. Released 2011. IBM SPSS Statistics for Windows, Version 20.0. Armonk, NY: IBM Corp.) and the pROC package in R (Version: 1.7.2 released on April 6th, 2014) (15). P-values $<0.05$ were considered statistically significant. 


\section{Results}

A total of 199 consecutive patients who were referred to our institution from the breast cancer screening program underwent CEM as part of their workup (mean age 58.4 years, range 49-75 years). Most recalls were caused by masses (76.4\%), followed by calcifications $(15.1 \%)$, asymmetry (5.0\%) and architectural distortions (3.5\%). At final diagnosis, $29.6 \%$ of the cases proved to be malignant. Detailed patient characteristics were summarized in Table 1. Table 2 presents detailed information of sensitivity and specificity for all readers. For the entire reading panel, diagnostic performance parameters improved when using CEM. Mean sensitivity increased from $93.0 \%$ to $96.9 \%$ and mean specificity from $35.9 \%$ to $69.7 \%$. Mean PPV and NPV increased from $38.7 \%$ and $92.6 \%$ to $58.2 \%$ and $98.2 \%$, respectively. The ROC curves showed an improvement in diagnostic performance for all readers when using CEM (Figure 1). For all readers combined, the AUC value increased from 0.645 to 0.833 ( $p<0.0001$ ). Detailed results for the comparison of CEM and FFDM are presented in Table 3. Sensitivity increased for all reader panels but was only significantly increased for resident readers $(p=0.011)$ and for all readers together $(p=0.0002)$. Looking at the difference in sensitivity and specificity for CEM and FFDM both increased for all readers using CEM. For all subgroups of reader panels specificity was significantly increased. The interrater variability was considered to be excellent with a kappa value of 0.89 . 
ALL reviewers

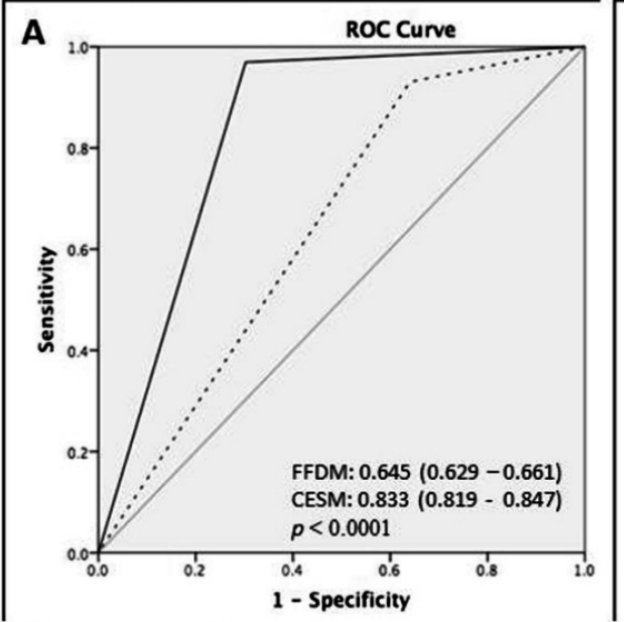

Non - Experienced reviewers

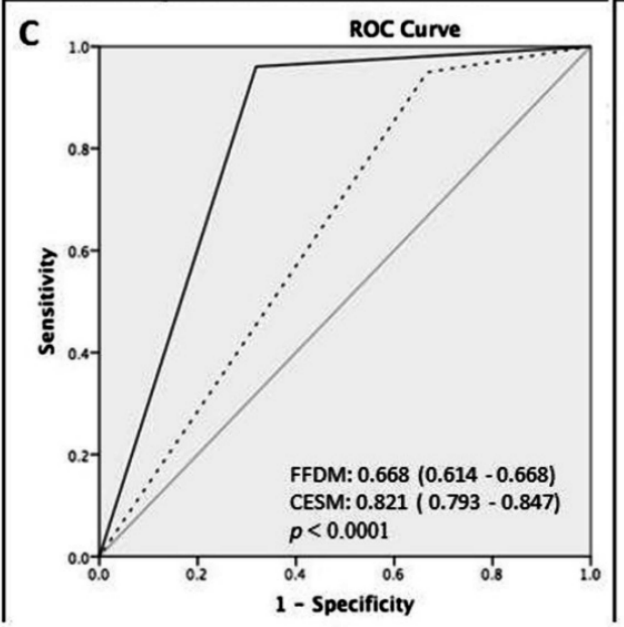

-- FFDM

- CESM

- Reference line

\section{Experienced reviewers}

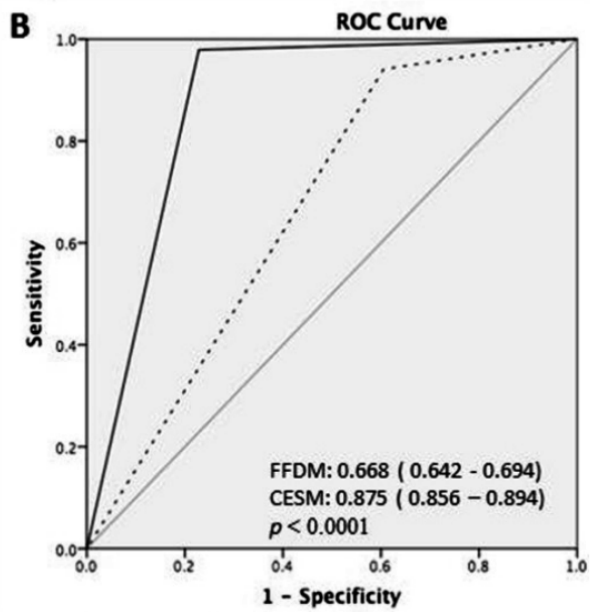

Resident reviewers

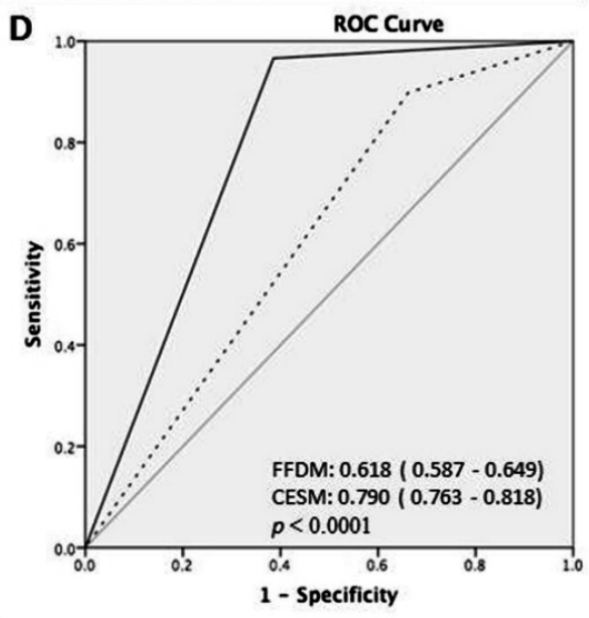

Figure 1. Average ROC curves for all readers (A), experienced CEM readers (B), experienced FFDM readers (C) and resident readers (D). AUC values for FFDM and CEM given with confidence intervals in parenthesis. Differences in AUC between FFDM and CEM were significantly increased for all subgroup of reader panels, $\mathrm{p}$-values given per subgroup of reader panel. 


$\begin{array}{lc}\text { Age } & \text { Years } \\ \text { Mean } & 58.4 \\ \text { Standard deviation } & 8.1 \\ \text { Range } & 49-75 \\ \text { Final Diagnosis } & \text { Percentage }(n=199) \\ \text { Malignant } & \\ \text { Invasive ductal carcinoma } & 22.1 \\ \text { Invasive lobular carcinoma } & 4.0 \\ \text { Ductal carcinoma in situ } & 2.5 \\ \text { Invasive mucinous carcinoma } & 0.5 \\ \text { Invasive micropapillary carcinoma } & 0.5 \\ \text { Benign } & \\ \text { Fibroadenoma } & 5.5 \\ \text { Simple cyst } & 19.1 \\ \text { Reactive changes / benign } & 1.5 \\ \text { Apocrine changes / metaplasia } & 3.5 \\ \text { Papilloma } & 1.5 \\ \text { Superposition } & 28.1 \\ \text { Cillindrical cell changes } & 2.0 \\ \text { Old hematoma } & 0.5 \\ \text { Inflammation } & 27.3 \\ \text { Intramammary lymphnode } & 2.0 \\ \text { Sclerosing adenosis } & 1.0 \\ \text { Atypical lobular hyperplasia } & 0.5 \\ \text { Ductectasia } & 1.0 \\ \text { Fibrosis } & 1.5 \\ \text { Ductal hyperplasia } & 1.0 \\ \text { Lobular carcinoma in situ } & 0.5 \\ \text { Flat epithelial atypia } & 0.5 \\ \text { Total } & 100.0 \\ \text { Invasive breast cancer subtypes } & \text { Percentage of all invasive cancers } \\ \text { ER positive } & 92.3 \\ \text { PR positive } & 80.8 \\ \text { HER2/neu positive } & 12.2 \\ \text { Grade 1 } & \\ \text { Grade 2 } & \\ \text { Grade 3 } & \\ \end{array}$

Table 1. Patient characteristics: age, final diagnosis for malignant and benign lesions and subtypes of invasive cancers given. Abbreviations: ER: estrogen receptor, PR: progesterone receptor, HER2/neu: Human Epidermal growth factor Receptor 2. 
Ten cases (5\%) with false negative CEM findings were observed. An overview of the final diagnosis, tumor characteristics and the number of readers that scored the individual case as false negative is presented in Table 4. Three readers had no false negative scores with CEM. All other readers had at least one false-negative finding on CEM (median 2 cases, range 14).

\begin{tabular}{|c|c|c|c|}
\hline Reader & Exam & Sensitivity & Specificity \\
\hline \multirow[t]{2}{*}{ Experienced CESM reader 1} & FFDM & $86.4 \%(75.0-93.9 \%)$ & $67.1 \%(58.7-74.8 \%)$ \\
\hline & CESM & $93.2 \%(83.5-98.1 \%)$ & $86.4 \%(79.6-91.6 \%)$ \\
\hline \multirow[t]{2}{*}{ Experienced CESM reader 2} & FFDM & $96.6 \%(88.2-99.4 \%)$ & $26.4 \%(19.3-34.5 \%)$ \\
\hline & CESM & $98.3 \%(90.8-99.7 \%)$ & $70.7 \%(62.4-78.1 \%)$ \\
\hline \multirow[t]{2}{*}{ Experienced CESM reader 3} & FFDM & $94.9 \%(85.8-98.9 \%)$ & $49.3 \%(40.7-57.8 \%)$ \\
\hline & CESM & $100.0 \%(93.8-100.0 \%)$ & $75.7 \%(67.7-82.6 \%)$ \\
\hline \multirow[t]{4}{*}{ Experienced CESM reader 4} & FFDM & $98.3 \%(90.8-99.7 \%)$ & $15.0 \%(9.5-22.0 \%)$ \\
\hline & CESM & $100.0 \%(93.8 \%-100.0 \%)$ & $75.7 \%(67.7-82.5 \%)$ \\
\hline & Mean FFDM & $94.1 \%(89.6-98.5 \%)$ & $39.5 \%(19.7-59.2 \%)$ \\
\hline & Mean CESM & $97.6 \%(95.1-100 \%)$ & $77.1 \%(71.5-82.7 \%)$ \\
\hline \multirow[t]{2}{*}{ Non-experienced CESM reader 1} & FFDM & $98.3 \%(90.8-99.7 \%)$ & $37.8 \%(29.8-56.4 \%)$ \\
\hline & CESM & $100.0 \%(93.8-100.0 \%)$ & $67.1 \%(58.7-74.8 \%)$ \\
\hline \multirow[t]{2}{*}{ Non-experienced CESM reader 2} & FFDM & $96.6 \%(88.2-99.5 \%)$ & $21.4 \%(14.9-29.1 \%)$ \\
\hline & CESM & $94.9 \%(85.8-98.8 \%)$ & $64.3 \%(55.7-72.2 \%)$ \\
\hline \multirow[t]{4}{*}{ Non-experienced CESM reader 3} & FFDM & $89.9 \%(79.1-96.1 \%)$ & $40.7 \%(32.5-49.3 \%)$ \\
\hline & CESM & $93.2 \%(83.5-98.1 \%)$ & $72.8 \%(64.7-80.0 \%)$ \\
\hline & Mean FFDM & $94.9 \%(90.8-99.0 \%)$ & $33.3 \%(23.7-42.9 \%)$ \\
\hline & Mean CESM & $95.9 \%(92.9-98.9 \%)$ & $68.0 \%(64.1-72.1 \%)$ \\
\hline \multirow{2}{*}{$\begin{array}{l}\text { Resident } \\
\text { Reader } 1\end{array}$} & FFDM & $89.8 \%$ (79.1-96.1\%) & $32.8 \%(25.1-41.3 \%)$ \\
\hline & CESM & $96.6 \%(88.2-99.4 \%)$ & $58.5 \%$ (49.9-66.8\% \\
\hline \multirow{2}{*}{$\begin{array}{l}\text { Resident } \\
\text { Reader } 2\end{array}$} & FFDM & $93.2 \%$ (83.5-98.0\%) & $36.4 \%$ (36.4-44.9\%) \\
\hline & CESM & $96.6 \%(88.2-99.4 \%)$ & $64.2 \%(55.7-72.2 \%)$ \\
\hline \multirow{4}{*}{$\begin{array}{l}\text { Resident } \\
\text { Reader } 3\end{array}$} & FFDM & $86.4 \%$ (75.0-93.9\%) & $32.1 \%(24.5-40.5 \%)$ \\
\hline & CESM & $96.6 \%$ (88.2-99.5\%) & $61.4 \%$ (52.8-69.5\%) \\
\hline & Mean FFDM & $89.8 \%(79.2-96 \%)$ & $33.7 \%(28.6-42.2 \%)$ \\
\hline & Mean CESM & $96.6 \%(95.4-98.2 \%)$ & $61.3 \%$ (52.8-69.5\%) \\
\hline \multirow[t]{2}{*}{ All readers mean } & FFDM & $93.0 \%(90.3-95.8 \%)$ & $35.9 \%(27.3-44.5 \%)$ \\
\hline & CESM & $96.9 \%(93.2-100.0 \%)$ & $69.7 \%$ (64.8-74.6\%) \\
\hline
\end{tabular}

Table 2. Diagnostic performance of FFDM and CEM for all ten readers. Diagnostic performance parameters were presented as percentages with $95 \%$ confidence intervals in parentheses 


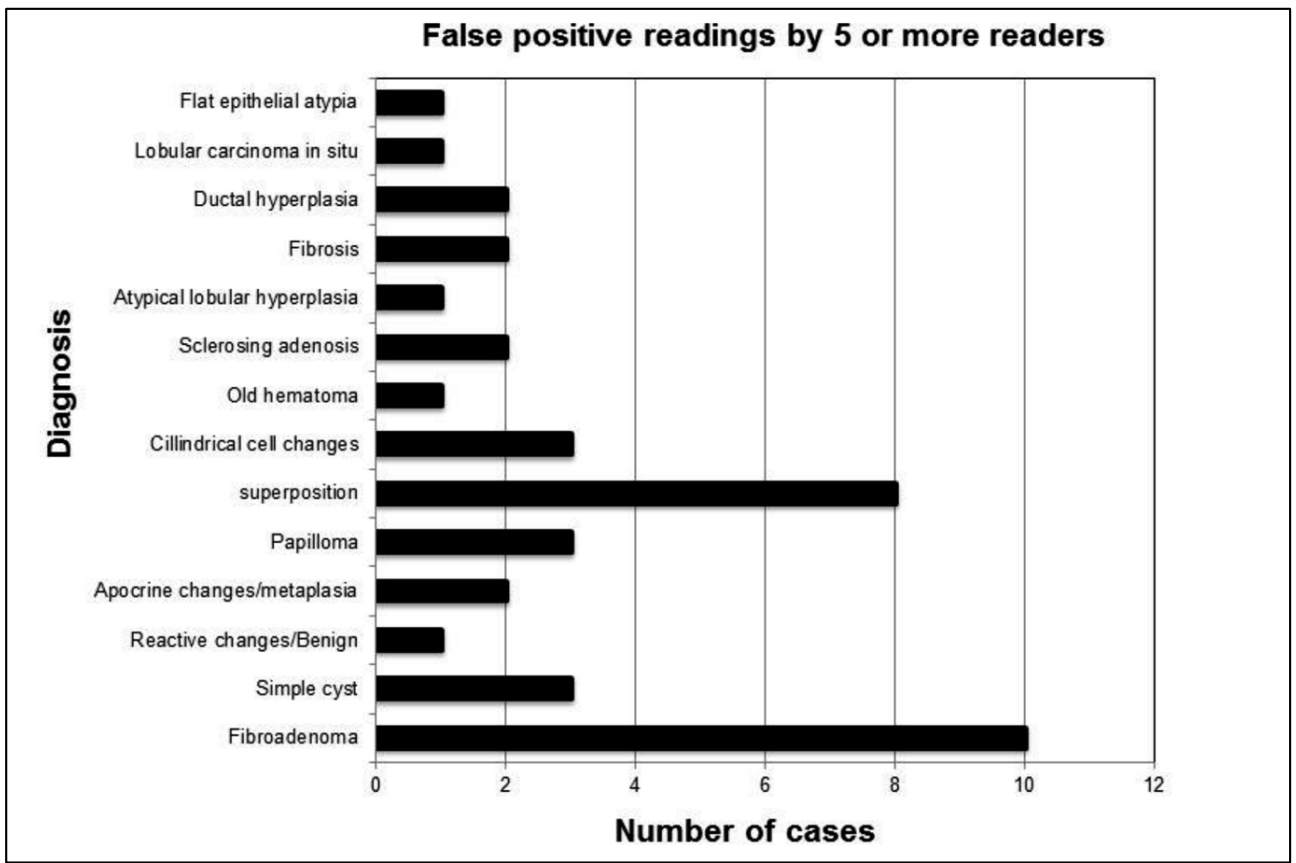

Figure 2. Overview of number of cases and diagnosis of false-positive findings. These cases were scored as false positive cases by five or more readers.

The mean number of false positive cases was 42 (21.1\%, range 19-58), with an average for the experienced CEM readers of 31 cases (15.6\%). The experienced FFDM readers showed an average of 37 false positive cases (18.6\%), whereas the residents showed 54 false positive findings $(27.1 \%)$. A total of 40 cases $(20.1 \%)$ were scored as false positive by five or more readers using CEM. In this sub group, the most common causes were fibro adenomas $(n=10)$, followed by superposition densities $(n=8)$, and cysts $(n=3)$. A detailed summary of this sub analysis is presented in Figure 2. 


\begin{tabular}{|c|c|c|c|c|}
\hline & $\begin{array}{l}\Delta \text { Sensitivity } \\
\text { CESM-FFDM }(95 \% \mathrm{CI})\end{array}$ & $\begin{array}{l}\text { p- value } \\
\text { ( }<0.05 \text { significant })\end{array}$ & $\begin{array}{l}\Delta \text { Specificity } \\
\text { CESM-FFDM }(95 \% \mathrm{Cl})\end{array}$ & $\begin{array}{l}\text { p-value } \\
(<0.05 \text { significant })\end{array}$ \\
\hline $\begin{array}{l}\text { Experienced CESM } \\
\text { readers }\end{array}$ & $0.035(-0.009-0.079)$ & $\mathrm{p}=0.114$ & $0.376(0.193-0.559)$ & $p=0.000056$ \\
\hline $\begin{array}{l}\text { Non-experienced } \\
\text { CESM readers }\end{array}$ & $0.010(0.036-0.056)$ & $p=0.667$ & $0.348(0.254-0.442)$ & $\mathrm{p}<0.00001$ \\
\hline $\begin{array}{l}\text { Resident } \\
\text { Readers }\end{array}$ & $0.068(0.016-0.120)$ & $p=0.011$ & $0.276(0.223-0.329)$ & $\mathrm{p}<0.00001$ \\
\hline All readers & $0.038(0.018-0.058)$ & $p=0.0002$ & $0.338(0.267-0.409)$ & $\mathrm{p}<0.00001$ \\
\hline
\end{tabular}

Table 3. Difference $(\Delta)$ in sensitivity and specificity of CEM and FFDM with $95 \%$ confidence intervals $(\mathrm{CI})$ in parenthesis. $\mathrm{p}$ values $<0.05$ are considered significant 


\begin{tabular}{|c|c|c|c|c|c|c|c|c|c|}
\hline \multirow{2}{*}{$\begin{array}{l}\text { Final } \\
\text { diagnosis } \\
\text { Histology }\end{array}$} & \multicolumn{4}{|c|}{ Number of readers scoring false negative } & \multicolumn{5}{|c|}{ Tumour Characteristics } \\
\hline & $\begin{array}{l}\text { Experienced } \\
\text { CESM }\end{array}$ & $\begin{array}{l}\text { Non- } \\
\text { experienced } \\
\text { CESM }\end{array}$ & Resident & Total & $\begin{array}{l}\text { diameter } \\
\text { in } \mathrm{mm}\end{array}$ & Grade & ER & PR & HER2/neu \\
\hline $\begin{array}{l}\text { Invasive } \\
\text { ductal } \\
\text { carcinoma }\end{array}$ & 1 & 2 & 2 & 5 & 14 & 2 & + & + & - \\
\hline $\begin{array}{l}\text { Invasive } \\
\text { ductal } \\
\text { carcinoma }\end{array}$ & 1 & 1 & 1 & 3 & 22 & 2 & + & + & + \\
\hline $\begin{array}{l}\text { Invasive } \\
\text { mucinous } \\
\text { carcinoma }\end{array}$ & - & 2 & - & 2 & 18 & 1 & + & + & - \\
\hline $\begin{array}{l}\text { Invasive } \\
\text { ductal } \\
\text { carcinoma }\end{array}$ & - & 1 & - & 1 & 20 & 2 & + & - & - \\
\hline $\begin{array}{l}\text { Invasive } \\
\text { ductal } \\
\text { carcinoma }\end{array}$ & 1 & - & - & 1 & 7 & 1 & + & + & - \\
\hline $\begin{array}{l}\text { Invasive } \\
\text { ductal } \\
\text { carcinoma }\end{array}$ & 1 & - & - & 1 & 4 & 1 & + & - & - \\
\hline $\begin{array}{l}\text { Invasive } \\
\text { ductal } \\
\text { carcinoma }\end{array}$ & - & - & 1 & 1 & 16 & 2 & + & + & - \\
\hline $\begin{array}{l}\text { Ductal } \\
\text { carcinoma in } \\
\text { situ }\end{array}$ & - & 1 & - & 1 & 10 & $2-3$ & $\mathrm{n} / \mathrm{a}$ & $\mathrm{n} / \mathrm{a}$ & $\mathrm{n} / \mathrm{a}$ \\
\hline $\begin{array}{l}\text { Invasive } \\
\text { lobular } \\
\text { carcinoma }\end{array}$ & - & - & 1 & 1 & 5 & 2 & + & + & - \\
\hline $\begin{array}{l}\text { Ductal } \\
\text { carcinoma in } \\
\text { situ }\end{array}$ & - & - & 1 & 1 & 26 & 3 & $\mathrm{n} / \mathrm{a}$ & $\mathrm{n} / \mathrm{a}$ & $\mathrm{n} / \mathrm{a}$ \\
\hline
\end{tabular}

Table 4. Diagnosis of false negative cases and the number of readers that scored them as false negative. Experience level is indicated of the number of readers that missed the lesion on CEM. In addition, lesion characteristics such as diameter (given in $\mathrm{mm}$ ), histologic grade, DCIS grade and hormonal receptor status (ER, PR, HER2NEU) are given. Hormone receptor status in case of pure DCIS is not evaluated and therefore not available (n/a) for these cases 


\section{Discussion}

CEM is a promising new breast imaging modality. In CEM, an iodine-based contrast agent is intravenously administered, after which dual-energy mammography is performed. As a result, the radiologist can view a low-energy image (which is similar to a conventional FFDM) and a recombined image, showing areas of enhancement. ${ }^{76}$ In a previous study it was shown that CEM is an excellent problem solving tool for women recalled from the breast cancer screening program. ${ }^{5}$ However, these results were based on an interim analysis of the institution's first 113 cases read by only two radiologists experienced in CEM. Our current study shows that these results were reproducible, even in a large number of cases read by a panel of ten different radiologists with varying experience in reading CEM exams. Mean sensitivity increased from $93.0 \%$ to $96.9 \%$ and mean specificity from $35.9 \%$ to $69.7 \%$. Mean PPV and NPV increased from $38.7 \%$ and $92.6 \%$ to $58.2 \%$ and $98.2 \%$, respectively.

Several publications have studied the diagnostic performance of CEM (Table 5). ${ }^{2-5} 8$ 17-22 In these studies, the mean sensitivity of CEM varied from $77.8-100.0 \%$, whereas mean specificity (if available) varied from $41-87.7 \%$. In some studies, specificity could not be calculated since all included subjects were diagnosed with breast cancer. ${ }^{3819}$ One study did not provide specificity but accuracy instead. ${ }^{22}$ The disease prevalence in the other studies (except the study by Lobbes et al.) were higher than our population (range 36-100\%). The reported prevalence of $36 \%$ concerned a study population where all subjects included had micro calcifications without an associated mass. ${ }^{21}$ However, breast cancer prevalence in clinical practice is low. It is interesting to study the diagnostic performance of CEM in populations with low breast cancer prevalence since it should not result in a large number of false-positive findings. 


\begin{tabular}{|lcclc|}
\hline Study & $\begin{array}{l}\text { Number of patients } \\
(\mathrm{n}=)\end{array}$ & Sensitivity (\%) & Specificity (\%) & $\begin{array}{l}\text { Disease } \\
\text { prevalence (\%) }\end{array}$ \\
\hline Lewin et al.(2003) & 26 & 100 & 86.7 & 50 \\
Dromain et al. (2011) & 144 & 93 & 63 & 56.3 \\
Dromain et al. (2012) & 110 & 91.9 & 46 & 56.7 \\
Fallenberg et al. (2013) & 80 & 100 & - & 100 \\
Jochelson et al. (2013) & 52 & 96 & - & 100 \\
Fallenberg et al. (2014)1 & 118 & $94.7^{*} / 95^{* *}$ & - & 100 \\
Lobbes et al. (2014) & 113 & 100 & 87.7 & 28 \\
Luczyńska et al. (2014) & 152 & 100 & 41 & 76 \\
Cheung et al (2014) & 89 & 92.7 & 67.9 & 72 \\
Luczyńska et al. (2015) & 118 & 100 & Not provided & 68.6 \\
Cheung et al (2015)2 & 52 & 90.9 & 83.78 & 37.7 \\
\hline Annotations: 1sensitivity for CESM alone ${ }^{*}$ ) and for CESM in combination with mammography(**). 2 \\
Patients with microcalcifications only.
\end{tabular}

Table 5. Studies comparing CEM and Mammography: number of patients included, sensitivity and specificity given for CEM. also disease prevalence based on number of lesions analysed in the included population is given, calculated from data given in study.

For this reason, Lobbes et al. studied CEM's diagnostic performance in women recalled from breast cancer screening, who had a breast cancer prevalence of $28.3 \% .^{5}$ They found that (when compared to FFDM) sensitivity increased from $96.9 \%$ to $100.0 \%$ and NPV increased from $97.1 \%$ to $100.0 \%$. Interestingly, the largest improvements were observed for specificity and PPV, increasing from $42.0 \%$ and $39.7 \%$ to $87.7 \%$ and $76.2 \%$, respectively. It was concluded that CEM was an excellent problem solving imaging modality for recalls from the breast cancer screening program, able to detect breast cancer accurately, while establishing false-positive recalls confidently.

An important limitation of the study by Lobbes et al. was that two readers experienced with CEM read the cases. However, in order to become clinically implemented, the reproducibility of test results of every new diagnostic imaging modality should be validated, preferably in larger study populations using multiple readers. Therefore, we used a panel of ten different readers with different experience in FFDM and CEM to evaluate 199 consecutive CEM exams of women recalled from the breast cancer screening program. 
Our current results confirmed prior observations, with an increase of all diagnostic performance parameters when using CEM, especially with respect to specificity and PPV. These improvements were observed for all readers, independent of their level of CEM experience. Current results are in line with another previously published study with relatively lower disease prevalence. Luczyńska et al. studied 157 breast lesions (breast cancer prevalence 38.3\%) using both FFDM and CEM. ${ }^{4}$ Sensitivity of CEM was $100 \%$, with a PPV and NPV of $77 \%$ and $100 \%$, respectively with an AUC of 0.86 . However, in their study only a single reader was used to view the exams. CEM has potential pitfalls, resulting in both false negative or false positive findings. In a study by Thibault et al. six false negative findings were observed: two invasive ductal carcinomas outside the field of view and four invasive lobular cancer. ${ }^{23}$ Fallenberg et al. (using three readers) found that when CEM was solely used one cancer was missed by all readers, four cancers were missed by two, and three by one reader. ${ }^{8}$ In our study a total of 10 false negative cases were observed, scored incorrectly by one or more readers. The cancers that were overlooked by more than one reader were analyzed case-by-case. These were: one invasive grade 2 ductal carcinoma missed by five readers, one invasive grade 2 ductal carcinoma missed by three readers, and one grade 1 invasive mucinous carcinoma missed by two readers. These cases are illustrated in Figure 3. Two cases consisted of a focal asymmetry with ill-defined margins, only partly visible on the MLO view only. These lesions showed only subtle or no enhancement on the recombined images (Figure 3A and 3B). Among the readers that missed these lesions were experienced CEM users as well as none experienced CEM users and residents. Future developments such as computer aided detection systems for CEM or contrast-enhanced digital breast tomosynthesis, could potentially reduce the risk of missing these types of lesions. The third case (missed by two readers) consisted of an ill-defined mass visible on both CC and MLO views with a central coarse calcification without any enhancement on the recombined images. Despite the lack of enhancement, it does not represent a typical 'eclipse' sign which is the CEM appearance of a cyst, consisting of a dark 'void' on the recombined images combined with a subtle rim enhancement, resembling a solar eclipse. ${ }^{5}$ This atypical appearance of the eclipse sign together with its irregular margin warranted additional targeted ultrasound. Final pathology showed a grade 1 mucinous carcinoma (Figure 3). Mucinous carcinomas can be a CEM pitfall due to lack of enhancement. This case demonstrates that readers should not only focus on the recombined images. They are an adjunct to the mammographic images, not a replacement. 

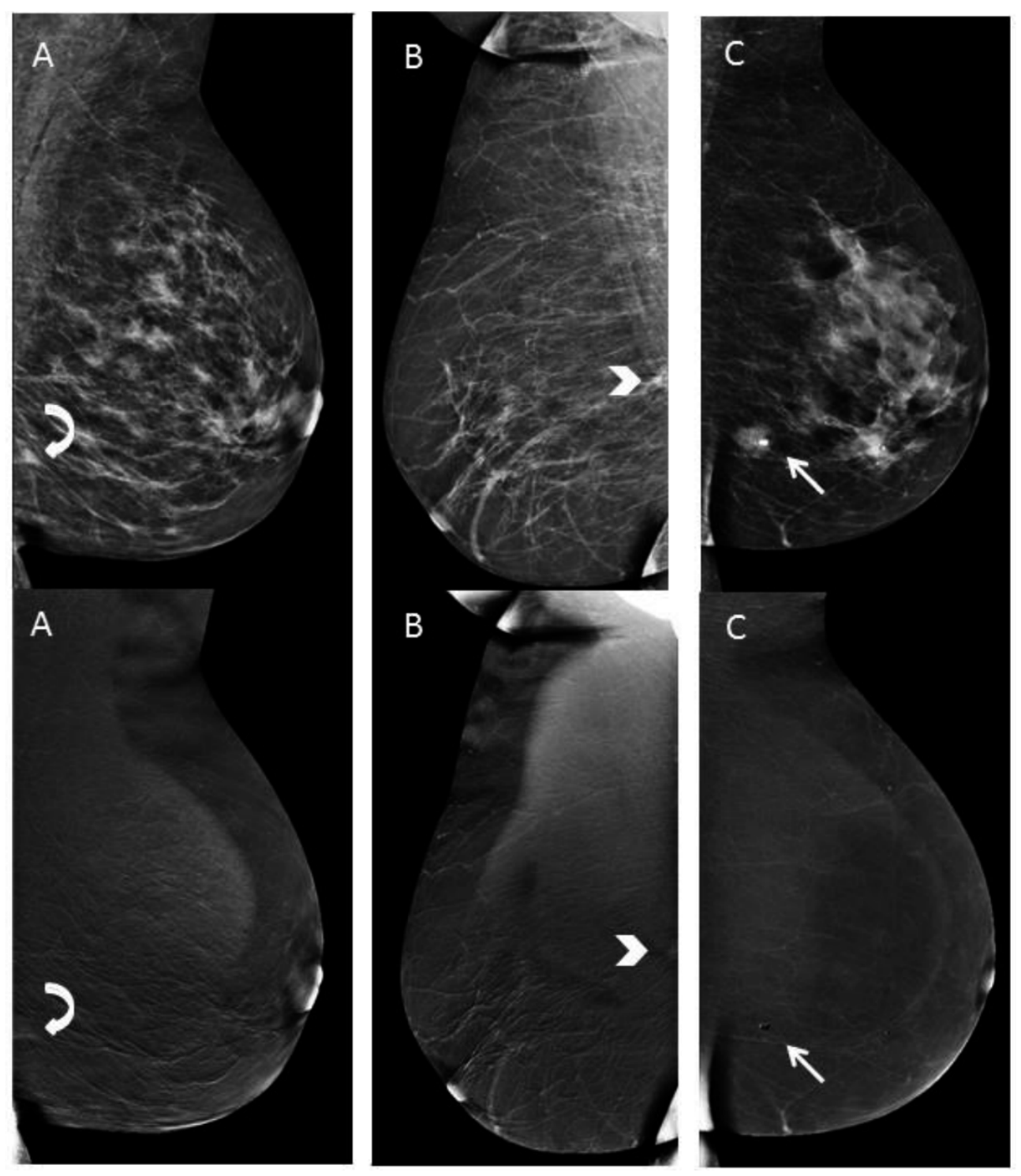

Figure 3. Example of false negative cases. Low-energy images at the top with corresponding recombined images underneath. A: infiltrating grade 2 ductal carcinoma with grade 3 ductal carcinoma in situ (curved arrow). B: invasive grade 2 ductal carcinoma (arrow head). C: grade 1 mucinous carcinoma (straight arrow). 
CEM also generates false positive findings. In the study by Badr et al. enhancement was observed in $33 \%$ of 27 benign lesions. ${ }^{24}$ Jochelson et al. detected two false positive results in 52 patients (4\%) using CEM. ${ }^{3}$ Lobbes et al. detected five false positive findings in a population of 113 women. ${ }^{5}$ Luczyńska et al. found 35 (20\%) false positive lesions with CEM compared to $50(29 \%)$ with conventional mammography. ${ }^{4}$ Similar to our observations, most of these lesions were caused by fibroadenomas $(n=26)$ or some other benign solid breast lesion. Although these findings resulted in tissue sampling which could have been avoided, its prevalence is low and do not outweigh the improved cancer detection rates caused by CEM when compared to FFDM. This study showed that CEM remains an excellent problem-solving tool for patients recalled from breast cancer screening, even when radiologists less experienced in CEM are reviewing the images. This implies that reading CEM exams hardly has any learning curve. Introduction into everyday clinical practice is safe and feasible. ${ }^{5}$ Using CEM in recalled patients increases specificity and PPV, thus providing the radiologist with a confident final diagnosis in cases of false positive recalls. For example, if recalled patients have a negative CEM exam the high NPV rules out the presence of breast cancer, preventing people from undergoing additional exams (such as breast MRI) or follow-up exams. Nevertheless, prospective randomized controlled trials are necessary comparing the standard work-up using conventional breast imaging with CEM-based work-up in order to accept CEM as a primary imaging tool in the work-up of recalled patients. 


\section{Study limitations}

Our study had some limitations. Earlier results were previously published and consisted of 113 cases read by two experienced CEM viewers. ${ }^{5}$ In the current study, these two readers were again participating in the scoring of the exams, thus re-scoring these exams. However, the data used was anonymized and the time period between the two scoring rounds was more than one year, minimizing the chances of introducing recall bias in these 113 cases. The remaining 86 cases were also new to these two readers. To prove that no recall bias was introduced, we performed additional analyses. In the previous publication, the AUC of ROC curve was 0.779 for mammography, increasing to 0.976 using CEM. ${ }^{5}$ These were the results of 113 cases. After more than one year, two readers reviewed these 113 cases again as part of the current study, achieving a diagnostic performance as expressed by the AUC value of 0.831 for mammography and 0.971 using CEM. The AUC value of the final 86 (completely new) cases was 0.881 for mammography and 0.977 for CEM. This shows that no recall bias is introduced during the rereading of the first 113 cases by these two readers. For the remaining eight readers all 199 cases are completely new. For reasons of comparison, we decided to include the complete data of the two experienced CEM reviewers to provide an overview of the performance of each reader for the entire case collection. However, in order to further assess the reproducibility of these results, it would be valuable to conduct a study consisting of an entirely different population, preferably in different institutes, using units of different vendors, that are now becoming commercially available. Second, there was no follow-up of cases with superposition of fibroglandular tissue as final diagnosis. However, our current imaging strategy of these cases complies with the NHSBSP's Clinical Guidelines for Breast Cancer Screening Assessment. ${ }^{12}$ This strategy is safe, with the chances of overlooking breast cancer being minimal, as was additionally proven by an institutional quality control covering almost 600 recalls from screening (personal communication). 
Third, all cases were recalls from the national breast cancer screening program. This introduced some selection bias since all patients were pre-selected by two screening radiologists. In addition, readers were not blinded for the reason of referral. However, the latter two limitations reflect everyday clinical practice of the work-up of recalled women. Finally, the additional value of (targeted) ultrasound next to FFDM was not taken into account since we wished to focus on the additional value of adding contrast and the recombined images to conventional mammography. Indeed, additional ultrasound could also clarify some findings that proved to be benign (such as a cyst). Since Dromain et al. showed that CEM is also superior to mammography and ultrasound combined ${ }^{2}$, it would still be recommendable to use CEM as a primary imaging tool for recalled patients. 


\section{Conclusion}

The diagnostic performance of CEM is superior to FFDM in women recalled from the breast cancer screening program, confirming previously published results. Even when used by less experienced CEM readers, CEM increases all diagnostic accuracy parameters, especially specificity and positive predictive value. 


\section{References}

1. Carney PA, Miglioretti DL, Yankaskas BC, et al. Individual and combined effects of age, breast density, and hormone replacement therapy use on the accuracy of screening mammography. Ann Intern Med 2003;138(3):168-75. doi: 10.7326/0003-4819-138-3200302040-00008 [published Online First: 2003/02/01]

2. Dromain C, Thibault F, Muller S, et al. Dual-energy contrast-enhanced digital mammography: initial clinical results. Eur Radiol 2011;21(3):565-74. doi: 10.1007/s00330-010-1944-y [published Online First: 2010/09/15]

3. Jochelson MS, Dershaw DD, Sung JS, et al. Bilateral contrast-enhanced dual-energy digital mammography: feasibility and comparison with conventional digital mammography and MR imaging in women with known breast carcinoma. Radiology 2013;266(3):74351. doi: 10.1148/radiol.12121084 [published Online First: 2012/12/12]

4. Luczynska E, Heinze-Paluchowska S, Dyczek S, et al. Contrast-enhanced spectral mammography: comparison with conventional mammography and histopathology in 152 women. Korean J Radiol 2014;15(6):689-96. doi: 10.3348/kjr.2014.15.6.689 [published Online First: 2014/12/04]

5. Lobbes MB, Lalji U, Houwers J, et al. Contrast-enhanced spectral mammography in patients referred from the breast cancer screening programme. Eur Radiol 2014;24(7):1668-76. doi: 10.1007/s00330-014-3154-5 [published Online First: 2014/04/04]

6. Stacul F, van der Molen AJ, Reimer P, et al. Contrast induced nephropathy: updated ESUR Contrast Media Safety Committee guidelines. Eur Radiol 2011;21(12):2527-41. doi: 10.1007/s00330-011-2225-0 [published Online First: 2011/08/26]

7. Lobbes MB, Smidt ML, Houwers J, et al. Contrast enhanced mammography: techniques, current results, and potential indications. Clin Radiol 2013;68(9):935-44. doi: 10.1016/j.crad.2013.04.009 [published Online First: 2013/06/25]

8. Fallenberg EM, Dromain C, Diekmann F, et al. Contrast-enhanced spectral mammography: Does mammography provide additional clinical benefits or can some radiation exposure be avoided? Breast Cancer Res Treat 2014;146(2):371-81. doi: 10.1007/s10549-0143023-6 [published Online First: 2014/07/06] 
9. Francescone MA, Jochelson MS, Dershaw DD, et al. Low energy mammogram obtained in contrast-enhanced digital mammography (CEDM) is comparable to routine full-field digital mammography (FFDM). Eur $J$ Radiol 2014;83(8):1350-5. doi: 10.1016/j.ejrad.2014.05.015 [published Online First: 2014/06/17]

10. Lalji UC, Jeukens CR, Houben I, et al. Evaluation of low-energy contrast-enhanced spectral mammography images by comparing them to full-field digital mammography using EUREF image quality criteria. Eur Radiol 2015;25(10):2813-20. doi: 10.1007/s00330015-3695-2 [published Online First: 2015/03/31]

11. Obuchowski NA. Receiver operating characteristic curves and their use in radiology. Radiology 2003;229(1):3-8. doi: 10.1148/radiol.2291010898 [published Online First: 2003/10/02]

12. Liston J WR. HSBSP clinical guidelines for breast cancer screening assessment. NHS Screening programmes, 2010.

13. NABON. National guideline breast cancer. In: (NABON) NBON, ed. Amsterdam, 2012.

14. Genders TS, Spronk S, Stijnen T, et al. Methods for calculating sensitivity and specificity of clustered data: a tutorial. Radiology 2012;265(3):910-6. doi: 10.1148/radiol.12120509 [published Online First: 2012/10/25]

15. Robin X, Turck N, Hainard A, et al. pROC: an open-source package for R and S+ to analyze and compare ROC curves. BMC Bioinformatics 2011;12:77. doi: 10.1186/1471-210512-77 [published Online First: 2011/03/19]

16. Lalji U, Lobbes M. Contrast-enhanced dual-energy mammography: a promising new imaging tool in breast cancer detection. Womens Health (Lond) 2014;10(3):289-98. doi: 10.2217/whe.14.18 [published Online First: 2014/06/24]

17. Lewin JM, Isaacs PK, Vance V, et al. Dual-energy contrast-enhanced digital subtraction mammography: feasibility. Radiology 2003;229(1):261-8. doi: 10.1148/radiol.2291021276 [published Online First: 2003/07/31]

18. Dromain C, Thibault F, Diekmann F, et al. Dual-energy contrast-enhanced digital mammography: initial clinical results of a multireader, multicase study. Breast Cancer Res 2012;14(3):R94. doi: 10.1186/bcr3210 [published Online First: 2012/06/16]

19. Fallenberg EM, Dromain C, Diekmann F, et al. Contrast-enhanced spectral mammography versus MRI: Initial results in the detection of breast cancer and assessment of tumour size. Eur Radiol 2014;24(1):256-64. doi: 10.1007/s00330-013-3007-7 [published Online First: 2013/09/21] 
20. Cheung YC, Lin YC, Wan YL, et al. Diagnostic performance of dual-energy contrastenhanced subtracted mammography in dense breasts compared to mammography alone: interobserver blind-reading analysis. Eur Radiol 2014;24(10):2394-403. doi: 10.1007/s00330-014-3271-1 [published Online First: 2014/06/15]

21. Cheung YC, Tsai HP, Lo YF, et al. Clinical utility of dual-energy contrast-enhanced spectral mammography for breast microcalcifications without associated mass: a preliminary analysis. Eur Radiol 2016;26(4):1082-9. doi: 10.1007/s00330-015-3904-z [published Online First: 2015/07/15]

22. Luczynska E, Heinze-Paluchowska S, Hendrick E, et al. Comparison between breast MRI and contrast-enhanced spectral mammography. Med Sci Monit 2015;21:1358-67. doi: 10.12659/MSM.893018 [published Online First: 2015/05/13]

23. Thibault F, Balleyguier C, Tardivon A, et al. Contrast enhanced spectral mammography: better than MRI? Eur J Radiol 2012;81 Suppl 1:S162-4. doi: 10.1016/S0720048X(12)70068-2 [published Online First: 2013/06/13]

24. Badr S, Laurent N, Regis C, et al. Dual-energy contrast-enhanced digital mammography in routine clinical practice in 2013. Diagn Interv Imaging 2014;95(3):245-58. doi: 10.1016/j.diii.2013.10.002 [published Online First: 2013/11/19] 



\section{Chapter 4}

Contrast-enhanced spectral mammography as work-up tool in patients recalled from breast cancer screening has low risks and might hold clinical benefits.

I.P.L. Houben, P. van de Voorde, C.R.L.P.N. Jeukens, J.E. Wildberger, L. Kooreman, M.L. Smidt, M.B.I. Lobbes.

European Journal of Radiology. 2017, 94, 31-37. 



\section{Abstract}

Objective - CEM is an excellent problem-solving tool in the work-up of women recalled from breast cancer screening. We evaluated additional findings caused by CEM alone and outweighed them against the disadvantages of CEM.

Methods - From December-2012 to December-2015, all women recalled from screening who underwent CEM were considered eligible. Radiation exposure and the number of adverse contrast reactions were analysed. An experienced breast radiologist reviewed all exams and identified cases with lesions detected by CEM alone. From these, the following data were collected: breast density, final diagnosis and consequences of their detection. For malignant cases TNM-stage, tumour grade and receptor characteristics were collected.

Results - During this study, 839 women underwent CEM after a breast cancer screening recall, in which five minor adverse contrast reactions were observed. Median radiation dose per exam was 6.0mGy (0.9-23.4mGy). Seventy CEM-only lesions were detected in 65 patients $(7.7 \%)$. Of these, $54.3 \%$ were malignant, with surgical management being altered in $75 \%$ of the cases.

Conclusion - When using CEM as a work-up tool for women recalled from screening, the advantages outweigh the increased radiation exposure, risks associated with contrast administration and the limited amount of supplementary biopsies of CEM-induced false positive findings. 


\section{Introduction}

CEM has shown to be consistently superior to FFDM. ${ }^{12}$. Previous studies concluded that CEM is an excellent problem-solving tool in patients recalled from a national breast cancer screening program. ${ }^{34}$ In these studies, the use of CEM as a work-up tool in recalled women resulted in an increase in all diagnostic performance parameters, mainly specificity and positive predictive value. $^{3}$

However, these results reflected CEM's performance on a patient-to-patient level. Several risks and benefits associated with CEM use are not considered in these parameters, such as the detection of occult breast cancer or the identification of multifocal tumours where unifocal tumours were suggested by the initial recall. Disadvantages of CEM include an increase in radiation dose 5 , the use of iodine-based contrast agents (which might cause adverse anaphylactic reactions) and additional false positive findings induced by CEM alone.

In this study, we aimed to analyse the risk and benefits of using CEM in patients recalled from screening. We evaluated the additional findings that were found by CEM alone compared to the original FFDM performed by the screening institute. Furthermore, we studied the number of CEM-induced false positive findings and the number of CEM-detected breast cancers being either mammographically occult cancers or multifocal lesions where unifocal abnormalities were primarily recalled. These observations were weighted against the number of adverse contrast agent reactions and the total radiation dose used in a complete CEM exam. 


\title{
Materials and methods
}

\author{
Study design
}

In the Netherlands women between 50 and 75 years are invited to participate in the national breast cancer screening program in which they undergo FFDM biennially. ${ }^{6}$ If a breast abnormality is detected by two independent certified screening radiologists (three in cases of discrepancies), women are recalled to a hospital of their choice for further imaging. In our institute, CEM is the primary imaging tool for the diagnostic work-up of these patients. All women recalled from screening in the period December 2012 to December 2015 and who underwent CEM as part of their work-up were considered to be eligible. Contra-indications for CEM were known anaphylactic reactions to iodine based contrast agents, increased risk of developing contrast-induced nephropathy (as assessed by the guidelines defined by European Society of Urogenital Radiology_(ESUR) on contrast media) ${ }^{7}$ and breast implants. Also excluded were patients who underwent CEM for an alternate indication (such as breast MRI alternative) or response monitoring in patients who received neoadjuvant chemotherapy. Due to its retrospective study design, the acquisition of informed consent was waived by our local ethics committee (METC decision number 16-4-099).

For all cases, the incidence of adverse contrast reactions (including its grade of severity) and radiation exposure used in each CEM exam was collected. For the cases containing additional CEM-only lesions the following data was collected: breast density, diagnosis of additional findings, and consequences of the CEM-detected findings.

\section{Imaging protocol and radiation exposure}

All examinations were performed on two identical CEM-compatible mammography systems (Senographe Essential with Senobright* upgrade, GE Healthcare, Chalfont, United Kingdom). The CEM imaging protocol was described previously. ${ }^{89}$ In short, a non-ionic monomeric, lowosmolar contrast agent was administered intravenously (iopromide, Ultravist 300; Bayer Healthcare, Germany) two minutes before the first image acquisition. A dose of $1.5 \mathrm{ml} / \mathrm{kg}$ body weight was administered with a flow rate of $3 \mathrm{ml} / \mathrm{s}$ followed by a saline flush. 
Standard MLO and CC views were obtained with additional views being requested by the radiologist if deemed necessary. Images and data, such as radiation exposure-related data, were stored in a dedicated PACS (IMPAX version 6.5, AGFA Healthcare, Mortsel, Belgium).

The occurrence of adverse contrast reactions in patients were collected from the radiology report and/or patient files. Based on these reports, the adverse reactions were categorized according to the ESUR guidelines as mild (i.e. itching, nausea, urticarial, mild vomiting), moderate (i.e. marked urticaria, vasovagal attack, facial/laryngeal edema, bronchospasm, severe vomiting) or severe (i.e. hypotensive shock, respiratory arrest, cardiac arrest, convulsion). ${ }^{7} 10$

Radiation exposure was determined by calculating the average glandular dose (AGD), as it is the radiation absorbed by the glandular tissue that is related to health detriment. The AGD was determined following the European guidelines ${ }^{11}$, which uses the Dance model ${ }^{12}{ }^{13}$ according to methods described previously. ${ }^{14}$ In short, for both mammography units tube output and half value layer (HVL) was measured for low and high energy spectra separately.

For the low energy spectra, a dosimeter calibrated for the target/filter combinations observed in the clinical images (Piranha; RTI Electronis, Molndall, Sweden) was used.

For the high energy spectra, a dedicated $1.5 \mathrm{~mL}$ ionization chamber was used (PS-033), combined with a Capintec 192A electrometer (Capintec Inc, Ramsey, NJ). The high energy tube output was determined by the difference of two measurements: 1 low- and high-energy cumulative measures and 2) low energy measures using a setting of CEM exposure parameters in FFDM mode. The remaining technical parameters required for the AGD calculation, i.e. $\mathrm{kV}$, target, filter, current-time product and CBT, were obtained for each exposure from the DICOM header of the images. In case of unilateral examination of the breast due to a previous mastectomy of contralateral breast, the given radiation dose for contralateral side was set on 0 mGy. The life attributable risk (LAR) was calculated using the LAR-values reported in the BEIR VII report. ${ }^{15}$ The LAR calculations were based on the AGD of one full exam for the ages of 40,60 and 80 years.

For all included patients, one breast radiologist (screening certified and with more than five years of CEM reading experience) reviewed the images on a dedicated mammography workstation (IDI MammoWorkstation 4.7.0, GE Healthcare, Chalfont St Giles, UK) customized with mammography-approved monitors (Barco Coronis 5MP Mammo, Barco, Kortrijk, Belgium). The correspondence letter of the screening institute, in which the recalled 
lesion(s) was (were) annotated, was made available prior to image review. Based on this knowledge, the radiologist identified any additional observations that were made during the exams solely on the basis of CEM information. The detection of additional benign lesions based on CEM were considered as disadvantage, since it would result in (unnecessary) additional procedures without any patient benefit. The detection of additional tumour foci by CEM alone, it being either additional foci next to a unifocal recalled lesion or the detection of an otherwise mammographically occult cancer, was considered to be an advantage of CEM-based work up of recalled patients (Figure 1).

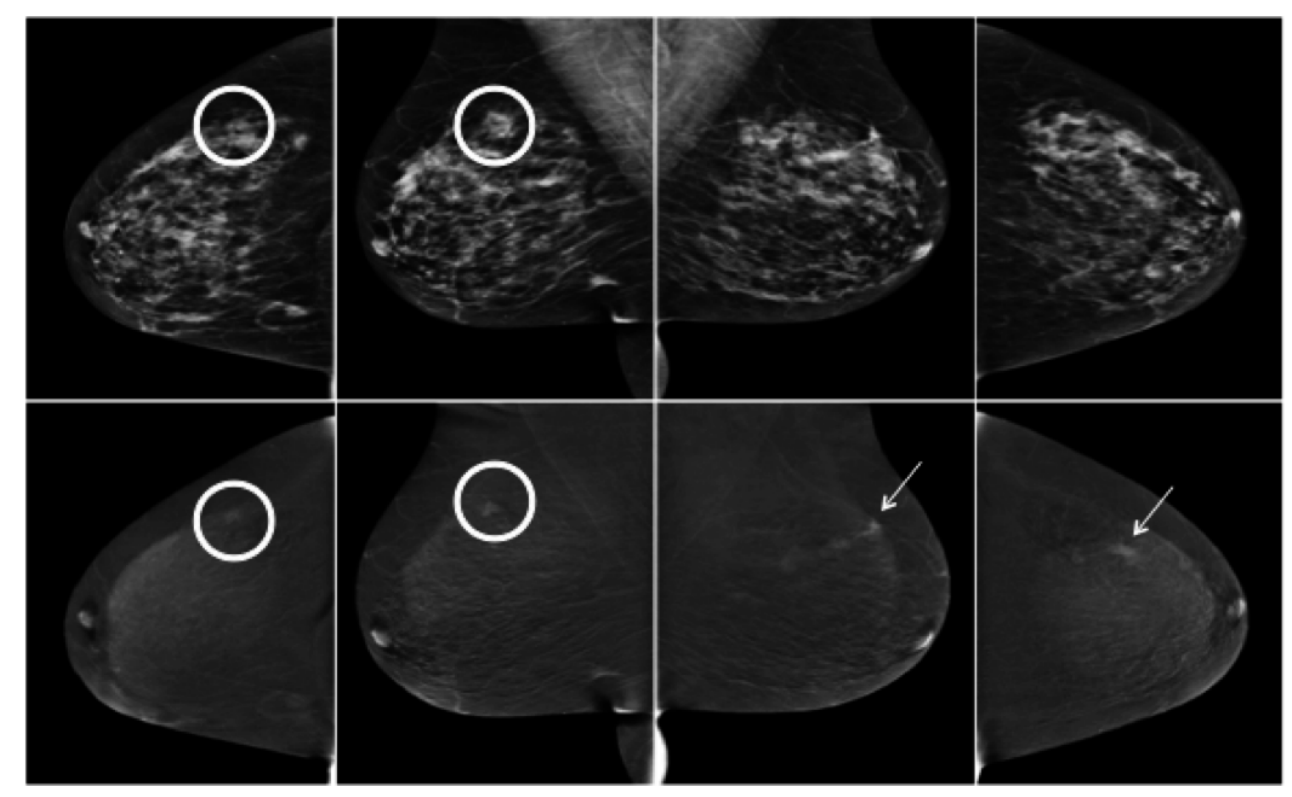

Figure 1. Example of an additional CEM-detected lesion. Upper rows show the low-energy CEM images which are similar to a full-field digital mammography. Bottom row show the recombined images with information on contrast uptake. This 63-year old female was recalled for an ill-defined, isodens, irregular mass in the upper outer quadrant of the right breast (circle). Histopathology revealed invasive ductal carcinoma. As additional finding, an irregular enhancing mass detected in the upper outer quadrant of the left breast, not visible on the concomitant low-energy images (arrow). Histopathology revealed an invasive lobular carcinoma. 
Breast density classification was collected from the radiology report and was assessed using the definitions provided in the BI-RADS lexicon by visual inspection and classified as follows: (1) the breasts are almost entirely fatty, (2) there are scattered areas of fibroglandular density, (3) the breasts are heterogeneously dense and (4) the breasts are extremely dense. ${ }^{16}$

\section{Histopathological analysis}

For all additional (CEM-only) lesions, pathological examination after biopsy (in benign lesions) or surgical excision (in malignant or benign excised lesions) served as the gold standard.

Core biopsies were routinely processed and were immediately fixated with formalin and stained with haematoxylin and eosin according to current national guidelines. ${ }^{17}$ Pathology samples were routinely processed. Excisions were freshly lamellated for optimal formalin fixation, and afterwards grossed. Tumour size was measured with representative slides being taken, and subsequently paraffin embedded. $3 \mu \mathrm{m}$ haematoxylline eosin (HE) stained slides where obtained after which initial pathological analysis occurred. If necessary, additional immunohistochemical stains where performed for completing diagnosis. Microscopic tumour size assessment was linked to measurement on gross examination. Final tumour diameter (in $\mathrm{mm}$ ) was defined as the largest tumour size based on macroscopic and histopathological examination. Surrounding ductal carcinoma in situ (DCIS) was included in the assessment of maximum tumour diameter. In multifocal breast cancers, the maximum diameter was based on the primary index tumour. Final TNM classification after surgery was collected from the pathology report according to TNM Classification Atlas. ${ }^{18}$

For invasive breast cancers, tumour grade (Nottingham Histologic Score system; the ElstonEllis modification of the Scarff-Bloom-Richardson grading system ${ }^{19-21}$ and the final estrogen, progesterone or HER2 status were determined using the final pathology report according to national guidelines. For DCIS, receptor status was not assessed. ${ }^{22}$ All diagnostics was done by one single breast pathologist. 
Statistical analysis

In this retrospective analysis, descriptive statistics were used. All analyses were performed using SPSS (IBM SPSS Statistics; version 23. IBM Corporation and other(s) 2015 for Windows, Armonk, New York, USA). 


\section{Results}

During our study period 879 women underwent CEM. CEM was performed for an indication other than analysis after a screening recall in 39 cases. One patient with a breast implant was excluded. In the end, 839 cases fulfilled our inclusion criteria (Figure 2).

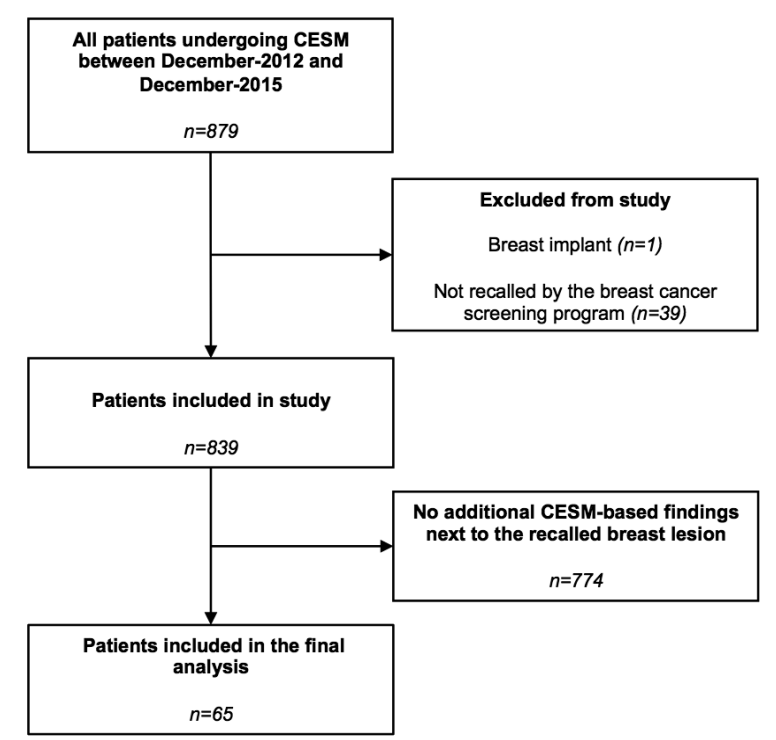

Figure 2. Flowchart of patient inclusion.

Patients ranged in age from 49 to 75 years (mean 59.6 years). A total of 70 CEM-based additional lesions (i.e. additional to the recalled lesion of interest) were detected in 65 patients. Of these patients, $26.2 \%$ had entirely fatty breasts, $52.3 \%$ had scattered areas of fibroglandular densities, $16.9 \%$ had heterogeneously dense breasts and $4.6 \%$ had extremely dense breasts.

Of the 70 CEM-based abnormalities, 32 (45.7\%) were benign. The 38 remaining abnormalities were malignant (54.3\%). In one patient CEM detected two separate benign lesions and in two patients two malignant lesions each.

Seven multifocal lesions were recalled as unifocal lesions and two malignant findings were mammographically occult multifocal tumours. One benign and one malignant additional finding was observed in two patients. All additional findings were presented in Table 1 and 2. 


\section{Disadvantages of CEM}

In the 839 patients that underwent CEM, five adverse reactions were observed (0.6\%). In four cases there were mild reactions, presenting as a few urticaria which resolved spontaneously after a prolonged observation at the department. Only one patient had a moderate reaction and was treated with an intravenous administration of $2 \mathrm{mg}$ clemastine (Tavegyl, Novartis Consumer Health, Breda, The Netherlands) and $200 \mathrm{mg}$ hydrocortisone (Solu-Cortef, Pfizer, Capelle aan den IJssel, The Netherlands). After treatment and a prolonged observation period symptom resolved completely.

Median (range) AGD of the left breast was 5.9 mGy (0 - $23.5 \mathrm{mGy})$, and $5.9 \mathrm{mGy}(0-23.4$ $\mathrm{mGy})$ for the right breast. Median number of views were $2(0-8)$ for the left and $2(0-8)$ for the right breast. The mean CBT was $58.8 \mathrm{~mm}$ (range $=11-220 \mathrm{~mm}, \mathrm{SD}=21 \mathrm{~mm}$ ). The LAR, of one full exam for the ages of 40, 60 and 80 years, was estimated to be $0.009 \%, 0.002 \%$ and $0.0003 \%$ for cancer incidence and a mortality of $0.002 \%, 0.0006 \%$ and $0.0001 \%$ for cancer mortality.

For benign additional abnormalities $(n=32)$, histopathology showed that these were most frequently caused by fibroadenomas (40.6\%), papilloma's (18.8\%) and hyperplasia (12.5\%). A detailed overview of the different causes of additional false-positive findings is presented in Figure 3. Diameters of benign abnormalities ranged from 5-21 mm (mean $9.4 \mathrm{~mm}$ ). Although all these lesions resulted in supplementary fine needle and core biopsies, no complications (such as hematomas or infection) were observed. 


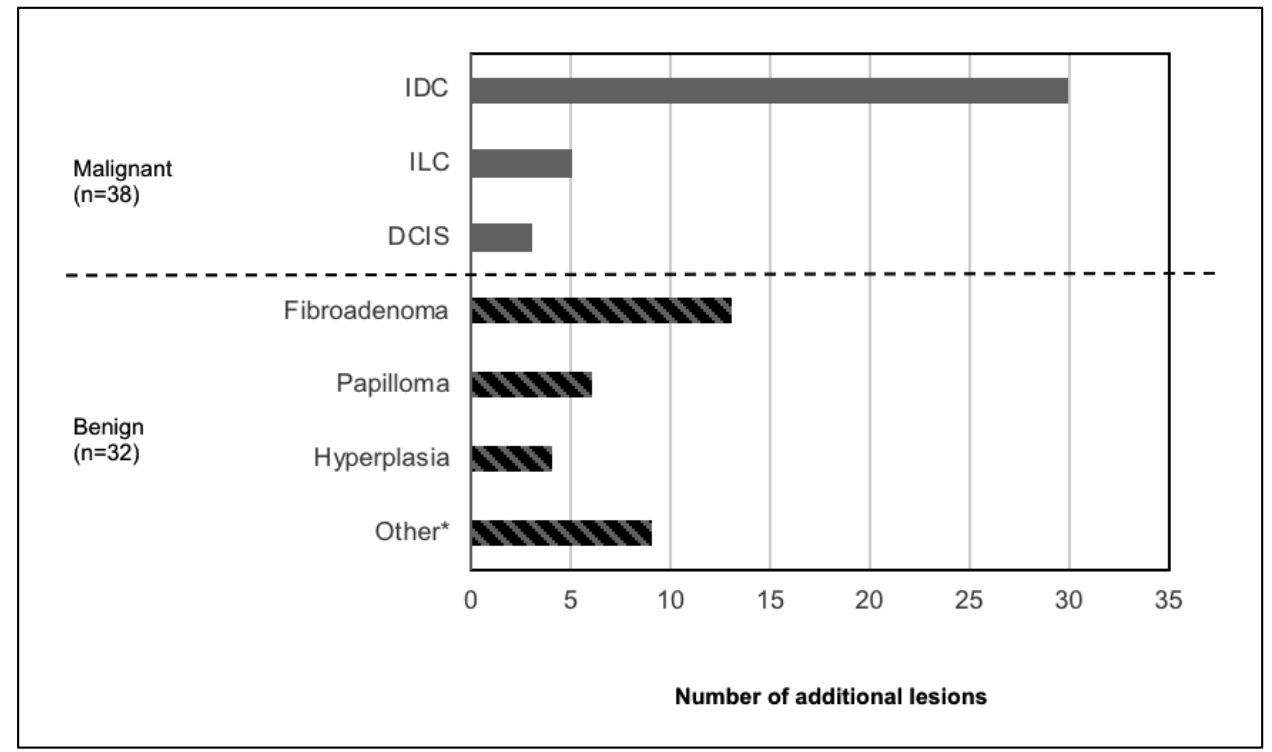

Figure 3. Number of diagnosed abnormalities.

*others include: adenosis, cylindrical cell changes, fat necrosis, fibrosis, hamartoma, pseudoangiomateus stromal hyperplasia, sebaceous cyst and cyst. Abbreviations: invasive ductal carcinoma (IDC); invasive lobular carcinoma (ILC); ductal carcinoma in situ (DCIS) 
Of all detected breast cancers $(n=38)$, invasive ductal carcinoma $(78.9 \%)$ was most frequently observed, followed by invasive lobular carcinoma (13.1\%) and ductal carcinoma in situ (7.9\%). Tumour characteristics of additionally detected malignant lesions varied. Malignant findings ranged in size from 3-50 $\mathrm{mm}$ (mean size $13.2 \mathrm{~mm}$ ). For the majority of invasive tumours these were classified as grade $1(34.3 \%)$ or grade $2(54.3 \%)$.

Concerning receptor characteristics, all malignant findings were estrogen receptor positive, the vast majority being progesterone receptor positive $(80.0 \%)$ and with $11.4 \%$ being HER2 positive (human epithelial growth factor receptor-2). All receptor characteristics are presented in Table 3.

Surgical management was changed in $75 \%$ of additional malignant cases $(n=36)$. In $38.9 \%$ surgery was necessary instead of no treatment, the other women underwent a more radical approach than indicated: $19.4 \%$ had a local wider excision, $25.0 \%$ mastectomy instead of a lumpectomy, $8.3 \%$ double lumpectomy instead of single lumpectomy, $2.7 \%$ bilateral mastectomy instead of unilateral mastectomy. All patient characteristics are presented in Table 4. 


\begin{tabular}{|c|c|c|}
\hline Additional findings & $n=70$ & (\%) \\
\hline$\overline{B e n i g n}$ & 32 & (45.7) \\
\hline Fibroadenoma & 13 & (40.6) \\
\hline Papilloma & 6 & $(18.8)$ \\
\hline Hyperplasia & 4 & $(12.5)$ \\
\hline Fibrosis & 1 & $(3.1)$ \\
\hline Fat necrosis & 1 & (3.1) \\
\hline Hamartoma & 1 & (3.1) \\
\hline Cylindrical cell changes & 1 & (3.1) \\
\hline Sebaceous cyst & 1 & (3.1) \\
\hline Adenosis & 1 & (3.1) \\
\hline Pseudoangiomatous stromal hyperplasia & 1 & (3.1) \\
\hline Simple cyst & 1 & (3.1) \\
\hline No specific abnormalities & 1 & (3.1) \\
\hline Malignant & 38 & (54.3) \\
\hline Invasive ductal carcinoma & 30 & (78.9) \\
\hline Invasive lobular carcinoma & 5 & $(13.1)$ \\
\hline Ductal carcinoma in situ & 3 & (7.9) \\
\hline Invasive breast cancer subtypes & $n=35$ & (\%) \\
\hline ER positive & 35 & $(100.0)$ \\
\hline $\mathrm{PR}_{\sim}^{\mathrm{b}}$ positive & 28 & $(80.0)$ \\
\hline $\mathrm{HER}^{\mathrm{c}}{ }^{\mathrm{p}}$ positive & 4 & (11.4) \\
\hline Grade 1 & 12 & (34.3) \\
\hline Grade 2 & 19 & (54.3) \\
\hline Grade 3 & 4 & (11.4) \\
\hline
\end{tabular}

Table 3. Final diagnosis of CEM-detected additional findings. Abbreviations: $\mathrm{ER}^{\mathrm{a}}$ : Estrogen receptor; $\mathrm{PR}^{\mathrm{b}}$ : progesterone receptor; $\mathrm{HER}^{\mathrm{c}}$ : human epidermal growth factor receptor 2 . 


\begin{tabular}{|c|c|c|}
\hline Age & \multirow{2}{*}{$\begin{array}{l}\text { All }^{1} \\
59.6\end{array}$} & \multirow{2}{*}{$\begin{array}{l}\text { Range } \\
49-75\end{array}$} \\
\hline Mean (years) & & \\
\hline \multirow[t]{2}{*}{ Standard deviation } & 8.0 & \\
\hline & CEM only $^{2}$ & Range \\
\hline Mean (years) & 60.0 & $50-74$ \\
\hline Standard deviation & 7.6 & \\
\hline Average glandular dose & All & Range \\
\hline Median (mGy) & 6.0 & $0.9-23.4$ \\
\hline Compressed breast thickness & All & Range \\
\hline Mean (mm) & 58.8 & $11-220$ \\
\hline Standard deviation & 21.0 & \\
\hline \multicolumn{3}{|c|}{ 1: Patients who underwent CEM ( $n=839)$. } \\
\hline \multicolumn{3}{|c|}{ 2: Patients with additional findings on CEM only $(n=65)$. } \\
\hline
\end{tabular}

Table 4. Patient characteristics. 


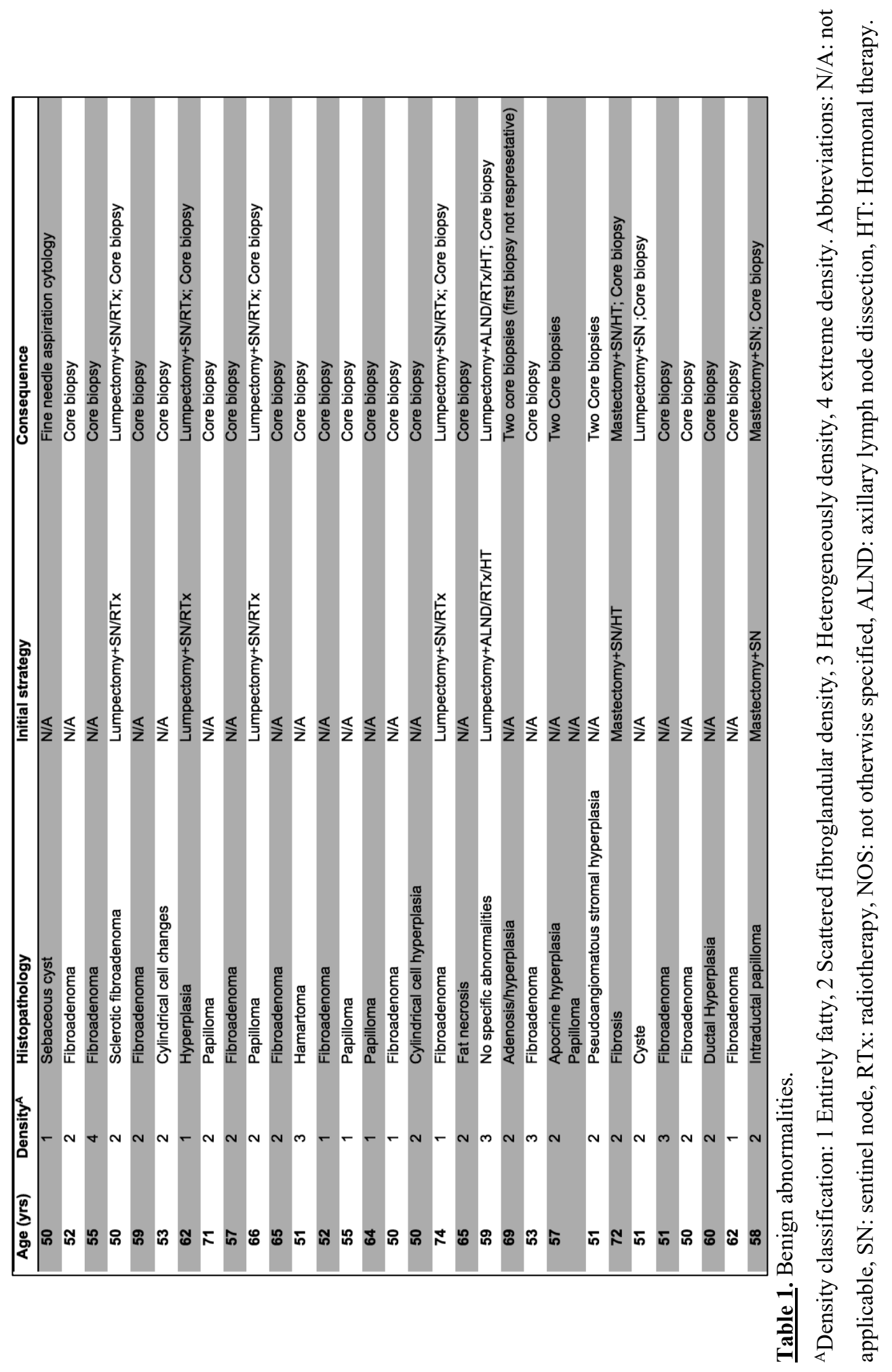




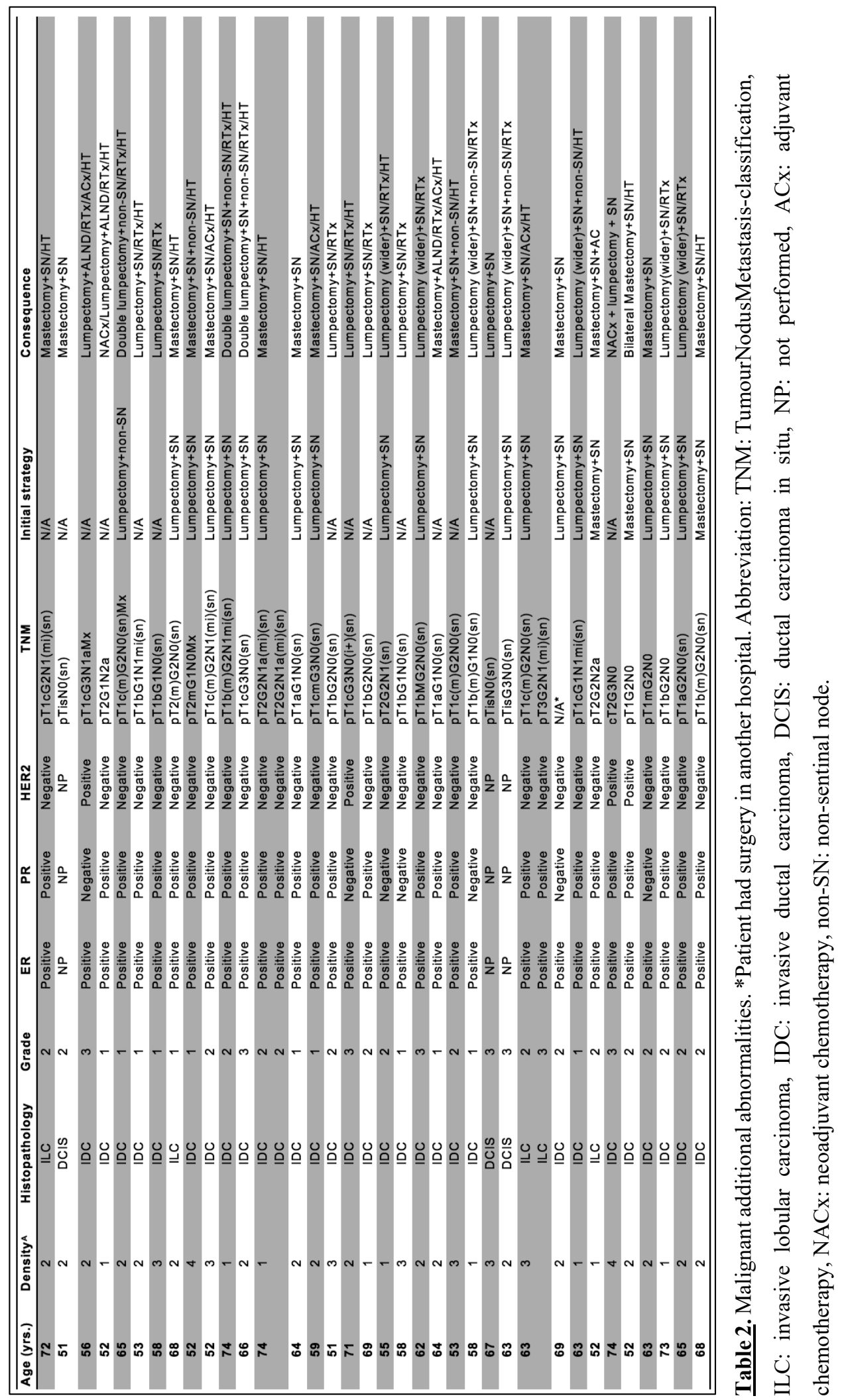




\section{Discussion}

The aim of this study was to analyse the risks and benefits of using CEM in patients recalled from screening by evaluating the additional findings that were caused by CEM alone and weighing them to the incidence of adverse reaction to contrast administration and radiation exposure used. In a study population of 839 women, CEM detected 70 additional findings in 65 patients (7.7\%): 38 lesions were malignant, 32 were benign. Surgical management was changed in $75 \%$ of the additional found malignant cases. Only five minor adverse reactions to contrast occurred, mostly self-limiting. Median radiation exposure per exam was $5.9 \mathrm{mGy}(0-$ 23.5) for the left and 5.9 mGy (0-23.4) for the right breast. Based on these findings, we feel confident to conclude that the benefits outweigh the risk of CEM-based work-up of recalled women.

Previously, Lalji et al. ${ }^{4}$ showed in a large population $(n=199)$ that in comparison to FFDM sensitivity remained stable when using CEM in patients recalled from breast cancer screening (96.9\%), whereas specificity and PPV increased considerably: $69.7 \%$ and $76.2 \%$, respectively. A negative CEM exam practically rules out breast cancer due to the high NPV (98.2\%) of CEM in this population. These results were consistent for multiple readers with varying experiences in reading CEM exams. These results were in line with a previous study performed by Lobbes et $a l^{3}$, in which 113 patients were evaluated with only two readers experienced in CEM exams. Although these results might sound advantageous, clinical CEM use also has some important disadvantages, such as: (1) additional (false-positive) findings that are observed (resulting in unwanted additional biopsies), (2) the increased radiation dose (potentially inducing breast cancer) and (3) the administration of iodine-based contrast agents (possibly causing (severe) adverse reactions). 


\section{Disadvantages of CEM-based work-up of recalled patients}

Five adverse reactions to the administration of contrast were reported in this study. Four patients suffered from mild reactions and did not require any medication. The complaints resolved spontaneously. One individual developed more extensive urticaria which required treatment, however they resolved completely afterwards. With the introduction of non-ionic iodinated contrast, the incidence of immediate hypersensitivity reactions has decreased. Nowadays, $0.7-3.1 \%$ of patients are estimated to develop mild adverse hypersensitivity reactions whereas $0.02-0.04 \%$ might developed severe adverse reactions when using these contrast agents. ${ }^{23}$ These numbers are in line with our current observations, with adverse reactions being observed in $0.6 \%$ of the cases.

Jeukens et al. showed that CEM has a higher radiation dose than FFDM. In this study, the mean radiation dose for CEM was $2.8 \mathrm{mGy} .{ }^{5}$ However, these numbers were for single exposures only. The mean of total radiation exposure of a complete CEM in our study was $5.9 \mathrm{mGy}$, in line with the results of Jeukens et al. and still being in compliance with the acceptable limits of the EUREF guidelines for screening. ${ }^{11}$ More importantly, the chances of tumour induction by this increased radiation dose are negligible, as shown by the LAR numbers per 100,000 persons of $0.002 \%-0.0003 \%$ for breast cancer incidence and $0.02 \%-0.001 \%$ for breast cancer mortality. Compared to the risks of contrast agent administration the radiation exposure related risks are much lower. According to the American association of physicists in medicine an effective radiation dose beneath $50 \mathrm{mGy}$ will not have adverse consequences. ${ }^{24}$

In this study, we observed 32 benign breast lesions that were only visible through the use of CEM. In other words, they were mammographically occult or did not present any concerns to the radiologist.

Due to the high PPV of CEM, it is recommended to acquire tissue sampling from lesions that are enhancing on CEM, even though these supplementary biopsies might be false-positive. Nowadays, patient discomfort during a biopsy procedure and complication rates are low. In a study by Parker et al., an incidence of $0.2 \%$ of biopsy-related complications was found, usually consisting of hematoma or infection. ${ }^{25}$ In all supplementary biopsies performed in our study, we encountered no such complications. In line with previous observations, the most common cause for false-positive CEM findings were fibroadenomas. ${ }^{14}$ 
Due to the increased diagnostic performance of CEM, we detected 38 malignant breast lesions that were either mammographically occult or were additional foci of a multifocal breast cancer that was deemed unifocal by the breast cancer screening radiologists. Although a previous study has shown that the diagnostic accuracy of CEM is more pronounced in extremely dense breast ${ }^{26}$, this was not reflected in our study population in which more than $78 \%$ of the cases with additional CEM-based findings consisted of either entirely fatty breasts or scattered areas of fibroglandular densities.

The detection of additional malignant foci has an important impact on patients, sometimes resulting in more aggressive treatment strategies. In the current study, surgical management was altered in $75 \%$ of the malignant cases. In a recent study by Tardivel et al., a change of diagnostic and surgical treatment was observed in $21 \%$ of the cases $(n=195)$. This discrepancy might be caused by the definition of the 'change in treatment'. In contrast to the study of Tardivel et al., we only focused on the changes in treatment for malignant cases, whereas Tardivel et al. also considered the avoidance of unnecessary biopsies in non-enhancing lesions (such as cysts) to be a change in (diagnostic) treatment. ${ }^{27}$ In our current study, ten patients were recalled from screening for a benign lesion, but breast cancer was detected solely by using CEM. These breast cancers would otherwise have been left untreated and might be detected as an interval carcinoma between screening rounds. Overall mortality of interval carcinomas is worse $(27 \%)$ than screen-detected breast cancers $(6 \%)$. The ten-year survival of interval carcinomas entails $70 \%$, versus $90 \%$ of screen-detected breast cancers. ${ }^{28}$ The impact of additional cancer foci next to an already detected breast cancer on the ipsilateral side is probably less pronounced, as these patients generally receive post-operative external-beam radiation of the whole breast with or without adjuvant systemic therapy. For contralateral breast cancers, Houssami et al. reported an increase in survival due to their early detection, albeit that the contralateral breast cancers in this study were detected in any kind of way. ${ }^{29}$ Whether knowledge of the presence of additional or occult tumour foci detected by CEM alone improves breast cancer survival needs to be studied further. 


\section{Study limitations}

The population of patients recalled from screening is a selected one, since two (or three in cases of discrepancies) radiologists decide whether a breast lesion should be recalled or not. In theory, a different set of patients could be selected if other radiologists would read the screening exams. However, this is common practice in the screening setting and reflects everyday clinical practice. Second, only a single radiologist screened all recalled patients for CEM-detected additional lesions. This radiologist did not include any extra lesions after the finalization of the exam but only assessed which lesion was recalled by screening and which lesion was detected by CEM only. For this reason, we selected a radiologist who is both experienced in breast cancer screening and CEM.

Third, there is no knowledge about any missed findings by our strategy. Hypothetically, breast cancers could also be occult for CEM or benign lesions could be misdiagnosed due to sample errors. Previous research by Lalji et al. ${ }^{4}$ showed that in recalls from screening CEM had a NPV of $98.2 \%$, limiting the number of overlooked cancers when using CEM. To confirm this assumption, we studied the screening results of the recalled women in this study after two years. A minimum follow-up period of two years was available for 607 out of 839 cases. None of those patients presented with new cancers during this period.

\section{Conclusion}

In conclusion, when using CEM as a work-up tool for women recalled from screening, additional CEM-only lesions are detected in $7.7 \%$ of the cases, the majority of them being malignant. In these additionally detected breast cancers, surgical management was changed in $75 \%$ of the malignant cases. In our opinion, this advantage outweighs the limited impact of increased radiation exposure, risks associated with contrast administration and supplementary biopsies of CEM-induced false positive findings. 


\section{References}

1. Luczynska E, Heinze-Paluchowska S, Dyczek S, et al. Contrast-enhanced spectral mammography: comparison with conventional mammography and histopathology in 152 women. Korean J Radiol 2014;15(6):689-96. doi: 10.3348/kjr.2014.15.6.689 [published Online First: 2014/12/04]

2. Thibault F, Balleyguier C, Tardivon A, et al. Contrast enhanced spectral mammography: better than MRI? Eur J Radiol 2012;81 Suppl 1:S162-4. doi: 10.1016/S0720048X(12)70068-2 [published Online First: 2013/06/13]

3. Lobbes MB, Lalji U, Houwers J, et al. Contrast-enhanced spectral mammography in patients referred from the breast cancer screening programme. Eur Radiol 2014;24(7):1668-76. doi: 10.1007/s00330-014-3154-5 [published Online First: 2014/04/04]

4. Lalji UC, Houben IP, Prevos R, et al. Contrast-enhanced spectral mammography in recalls from the Dutch breast cancer screening program: validation of results in a large multireader, multicase study. Eur Radiol 2016;26(12):4371-79. doi: 10.1007/s00330016-4336-0 [published Online First: 2016/04/22]

5. Jeukens CR, Lalji UC, Meijer E, et al. Radiation exposure of contrast-enhanced spectral mammography compared with full-field digital mammography. Invest Radiol 2014;49(10):659-65. doi: 10.1097/RLI.0000000000000068 [published Online First: 2014/05/30]

6. Timmers JM, van Doorne-Nagtegaal HJ, Zonderland HM, et al. The Breast Imaging Reporting and Data System (BI-RADS) in the Dutch breast cancer screening programme: its role as an assessment and stratification tool. Eur Radiol 2012;22(8):1717-23. doi: 10.1007/s00330-012-2409-2 [published Online First: 2012/03/15]

7. Reiser M. Contrast Media: Safety Issues and ESUR Guidelines Medical Radiology: Springer; 2014 [Third Edition]

8. Dromain C, Balleyguier C, Adler G, et al. Contrast-enhanced digital mammography. Eur J Radiol 2009;69(1):34-42. doi: 10.1016/j.ejrad.2008.07.035 [published Online First: 2008/09/16]

9. Lobbes MB, Smidt ML, Houwers J, et al. Contrast enhanced mammography: techniques, current results, and potential indications. Clin Radiol 2013;68(9):935-44. doi: 10.1016/j.crad.2013.04.009 [published Online First: 2013/06/25] 
10. Radiologie Kwaliteitsinstituut voor de gezondheid CBO en Nederlandse vereniging voor Radiologie. Richtlijn voorzorgsmaatregelen bij jodiumhoudende contrastmiddelen. Utrecht, NL2007 [2017].

11. European Reference Organisation for quality assured Breast Screening and Diagnostic Services (EUREF). European guidelines for Quality Assurance in breast cancer screening and diagnosis. 2017 [Available from: http://www.euref.org/europeanguidelines2017.

12. Dance DR, Skinner CL, Young KC, et al. Additional factors for the estimation of mean glandular breast dose using the UK mammography dosimetry protocol. Phys Med Biol 2000;45(11):3225-40. doi: 10.1088/0031-9155/45/11/308 [published Online First: 2000/12/01]

13. Dance DR, Young KC, van Engen RE. Further factors for the estimation of mean glandular dose using the United Kingdom, European and IAEA breast dosimetry protocols. Phys Med Biol 2009;54(14):4361-72. doi: 10.1088/0031-9155/54/14/002 [published Online First: 2009/06/25]

14. Lalji UC, Jeukens CR, Houben I, et al. Evaluation of low-energy contrast-enhanced spectral mammography images by comparing them to full-field digital mammography using EUREF image quality criteria. Eur Radiol 2015;25(10):2813-20. doi: 10.1007/s00330015-3695-2 [published Online First: 2015/03/31]

15. National Research Council (N.R.C.) Health Risks from Exposure to Low Levels of Ionizing Radiation: BEIR VII Phase II Washington DC, USA: The National Academies; 2006 [2017].

16. Sickles E.A. Basset L.W., et al. Breast Imaging Reporting and Data System. ACR BIRADS mammography Atlas: American College of Radiology 2013.

17. Integraal Kankercentrum Nederland (IKNL). Richtlijnen oncologische zorg (mammacarcinoom): Oncoline; 2017 [Available from: http://www.oncoline.nl/mammacarcinoom2017.

18. Sobin L. GM, et al. TNM Classification of Malignant Tumours 7th edition. 2009 [1-366]. 2017.

19. Bloom HJ, Richardson WW. Histological grading and prognosis in breast cancer; a study of 1409 cases of which 359 have been followed for 15 years. $\mathrm{Br} J$ Cancer 1957;11(3):359-77. doi: 10.1038/bjc.1957.43 [published Online First: 1957/09/01] 
20. Elston CW, Ellis IO. Pathological prognostic factors in breast cancer. I. The value of histological grade in breast cancer: experience from a large study with long-term follow-up. Histopathology 1991;19(5):403-10. doi: 10.1111/j.13652559.1991.tb00229.x [published Online First: 1991/11/01]

21. Rakha EA, El-Sayed ME, Lee AH, et al. Prognostic significance of Nottingham histologic grade in invasive breast carcinoma. J Clin Oncol 2008;26(19):3153-8. doi: 10.1200/JCO.2007.15.5986 [published Online First: 2008/05/21]

22. Nofech-Mozes S, Vella ET, Dhesy-Thind S, et al. Systematic review on hormone receptor testing in breast cancer. Appl Immunohistochem Mol Morphol 2012;20(3):214-63. doi: 10.1097/PAI.0b013e318234aa12 [published Online First: 2012/04/17]

23. Katayama H, Yamaguchi K, Kozuka T, et al. Adverse reactions to ionic and nonionic contrast media. A report from the Japanese Committee on the Safety of Contrast Media. Radiology 1990;175(3):621-8. doi: 10.1148/radiology.175.3.2343107 [published Online First: 1990/06/01]

24. American association of physicists in medicine. AAPM position statement on radiation risks from medical imaging procedures 2011 [Policy number PP25-A]. 2017.

25. Parker SH, Burbank F, Jackman RJ, et al. Percutaneous large-core breast biopsy: a multiinstitutional study. Radiology 1994;193(2):359-64. doi: 10.1148/radiology.193.2.7972743 [published Online First: 1994/11/01]

26. Mori M, Akashi-Tanaka S, Suzuki S, et al. Diagnostic accuracy of contrast-enhanced spectral mammography in comparison to conventional full-field digital mammography in a population of women with dense breasts. Breast Cancer 2017;24(1):104-10. doi: 10.1007/s12282-016-0681-8 [published Online First: 2016/03/05]

27. Tardivel AM, Balleyguier C, Dunant A, et al. Added Value of Contrast-Enhanced Spectral Mammography in Postscreening Assessment. Breast $J$ 2016;22(5):520-8. doi: 10.1111/tbj.12627 [published Online First: 2016/06/28]

28. Paajanen H, Kyhala L, Varjo R, et al. Effect of screening mammography on the surgery of breast cancer in Finland: a population-based analysis during the years 1985-2004. Am Surg 2006;72(2):167-71. [published Online First: 2006/03/16]

29. Houssami N, Ciatto S, Martinelli F, et al. Early detection of second breast cancers improves prognosis in breast cancer survivors. Ann Oncol 2009;20(9):1505-10. doi: 10.1093/annonc/mdp037 [published Online First: 2009/03/20] 




\section{Chapter 5}

Contrast-enhanced spectral mammography in the evaluation of breast suspicious calcifications: diagnostic accuracy and impact on surgical management.

I.P.L. Houben, S. Vanwetswinkel, V. Kalia, T. Thywissen, P.J. Nelemans, E.M. Heuts, M.L. Smidt, A. Meyer-Baese, J.E. Wildberger, M.B.I. Lobbes

Acta Radiologica, 2019. 60(9), 1110-1117. 



\section{Abstract}

Background - Detecting pathological breast calcifications remains challenging. Based on recent studies, CEM showed to be superior compared to FFDM.

Purpose - To evaluate the diagnostic accuracy of CEM in suspicious breast calcifications and its impact on surgical decision making.

Material and Methods - All screening recalled patients with suspicious calcifications that underwent CEM in the period October 2012 until September 2015 were included. One experienced radiologist provided a BI-RADS classification for the FFDM images only. The evaluation was repeated for the CEM exam. In a simulated tumor board meeting, two breast surgeons decided on the preferred surgical treatment (breast conservation therapy (BCT) versus mastectomy) for all malignant cases. Sensitivity, specificity, PPV and NPV were calculated defining $\mathrm{BI}-\mathrm{RADS} \geq 4$ as being malignant. In addition, differences in surgical decision making were analyzed and compared using the McNemar test.

Results - In total, 147 women were included in this study (mean age 61 years, range 49-75). Pathology showed 82 benign and 65 malignant lesions, of which 33 DCIS and 32 invasive lesions. Diagnostic performances of CEM (differences compared to FFDM in brackets) were: sensitivity $93.8 \%(+3 \%)$, specificity $36.6 \%(-2.5 \%)$, PPV 54\%(0\%), NPV 88.2\%(+4\%). Based on low-energy images, surgeons suggested BCT in $89 \%$ of the cases. Based on the CEM exam, no statistically changes in decisions were observed $(86 \% \mathrm{BCT}, p=0.453)$.

Conclusion - CEM only slightly improves the diagnostic accuracy of the evaluation of breast calcifications. It is not of added value compared to FFDM in guiding surgical decision making. 


\section{Introduction}

Although most suspicious breast calcifications are of benign origin, they can also be the predominant sign of DCIS. They might even be associated with an underlying (non-palpable) invasive breast cancer. FFDM plays a pivotal role in the detection and evaluation of suspicious breast calcifications, as demonstrated by the increased incidence of DCIS since the introduction of FFDM in breast cancer screening. ${ }^{1}$ Nevertheless, the evaluation of suspicious breast calcifications remains challenging, reflected by positive predictive values ranging from 18 $38 \%$. $^{2-6}$

Not only the detection of pathologic calcifications remains challenging, but also the assessment of disease extent in patients with DCIS or (non-palpable) invasive breast cancer. BCT surgery with positive margins is reported to occur in $34 \%$ of DCIS cases ${ }^{7}$, compared to $3-7 \%$ in patients with invasive (ductal or lobular) breast cancers. ${ }^{8}$ Even the use of contrast-enhanced breast MRI, which is generally regarded to be the most accurate imaging modality to assess disease extent $^{9}$, does not have any positive impact on the surgical management of DCIS. ${ }^{10}$

CEM was recently introduced as a novel mammographic technique. Studies in various study populations showed that CEM is consistently superior to $\mathrm{FFDM}^{11}$, for example in symptomatic patients $^{12}$, high risk patients ${ }^{13}$ and women recalled from the national breast cancer screening ${ }^{14}$, even when the latter is combined with targeted breast ultrasound. ${ }^{15}$ Lalji et al. showed that the image quality criteria regarding breast calcifications might be superior in the low-energy images of a CEM exam compared to FFDM. ${ }^{16}$ Some studies have shown that CEM matched or even outperformed breast MRI. ${ }^{17} 18$

Hypothetically, CEM would combine the best of all imaging modalities for the evaluation of calcifications: the visualization of calcium deposits on a mammographic (low-energy) image combined with information on increased local breast perfusion on the contrast-enhanced recombined images.

Therefore, our primary aim was to evaluate the diagnostic accuracy of CEM in suspicious breast calcifications. Our secondary goal was to study the ability of CEM to assess disease extent in patients with DCIS or invasive breast cancer, including its impact on surgical decision making. 


\section{Material and methods}

In our institute, CEM is mainly performed in recalls from the national breast cancer screening program. Included were women recalled from screening for suspicious calcifications (as indicated by the screening radiologists) in the period October 2012 until September 2015. Exclusion criteria were: Patients with known allergy or contra-indications for the use of iodinebased contrast agents, as well as patients with prior breast surgery (including breast implants). Due to the retrospective design of this study, the requirement for informed consent was waived by the local ethics committee (decision number METC 15-4-233).

\section{Image acquisition and analysis}

All CEM exams were performed for both breasts in the standard CC and MLO views using dedicated CEM unit (Senographe* Essential with Senobright* upgrade, GE Healthcare, Chalfont St Giles, United Kingdom). The CEM imaging protocol was described previously by Lobbes et al. ${ }^{19}$ In short, an iodine-based contrast agent (with a concentration $300 \mathrm{mg} / \mathrm{ml}$ iopromide, $1.5 \mathrm{~mL} / \mathrm{kg}$ bodyweight, Ultravist, Bayer Healthcare, Berlin, Germany) was intravenously administered with a flow rate of $3 \mathrm{~mL} / \mathrm{s}$ followed by saline flush two minutes prior to the acquisition of the first image. A typical CEM image therefore consists of a lowenergy image (LE, which is comparable to a full-field digital mammogram $)^{16}$ and a recombined image (in which areas of iodine accumulation can be detected) for both breast in two separate views.

All images were displayed on a dedicated mammography workstation (IDI MammoWorkstation 4.7.0, GE Healthcare), equipped with mammography-approved monitors (Barco Coronis 5MP Mammo, Barco, Kortrijk, Belgium). One reader, with 4 years of breast imaging experience, assessed the images, blinded for final histopathological results. The radiologist had never evaluated the images of this data set before. In this per lesion analysis, LE images were shown first with location of the (recalled) suspicious calcifications. The lesion was indicated by the correspondence letter supplied by the screening institute as in daily clinical practice. The calcifications were then scored according to the BI-RADS descriptors and a final BI-RADS classification was provided. ${ }^{20}$ For this study, the reader could subdivide BI-RADS category 4 into $4 a, 4 b$ or $4 c$. 
All lesions were measured using digital calipers. However, only the diameters of the malignant and in situ lesions were analyzed subsequently. Next, the complete CEM examinations were assessed (i.e. the combination of both LE and recombined images) and the reader could modify their final BI-RADS classification or maximum lesion diameter when deemed necessary.

In two separate sessions and simulating a multidisciplinary tumor board meeting, two dedicated breast surgeons (with 10 and 8 years of experience, respectively) assessed (in consensus) which surgical treatment (breast conserving therapy or mastectomy) would be recommended. During this decision making, only the malignant lesions were shown and its extent as described by the radiologist were made available to them, including information relevant for this decision, such as the pathological results, breast size or other relevant patient information (extracted from the patient files). In the first session, their decision was based on the LE images only. The session was repeated for the entire CEM exam after eight weeks to prevent any recall bias.

Histopathological results served as the gold standard for this study. For benign lesions, the histopathological results were based on core needle biopsies. For malignant cases, including DCIS, the final surgical specimens were used. Of all lesions, pathological results were thus available. Surgical specimens and biopsies were evaluated according to current national guidelines. $^{21}$ 


\section{Statistical analysis}

BI-RADS classifications 1 to 3 were considered benign, BI-RADS classification 4a, 4b, 4c and 5 were considered malignant. With this predefined cut off, we calculated sensitivity, specificity, PPV, NPV and area under the ROC curve (AUC) for both evaluations using pathology as reference standard. Since DCIS is a non-invasive (intraductal) cancer, we considered these lesions as malignant in this study. Discrepancies between measurements of disease extent in histopathological specimens (considered as the gold standard) and measurements on LE and CEM images, were visualized in Bland-Altman plots. Pearson's correlation coefficients (PCC) for LE and CEM were also calculated. ${ }^{22}$ The mean value of the discrepancies with histopathological size measurements quantifies systematic measurement error and the $95 \%$ limits of agreement (LOA) quantify random measurement error. To evaluate whether use of CEM compared to LE has impact on surgical management decisions, the frequency of concordant and discordant decisions was recorded.

The McNemar test was used to test for statistical significance. Statistical analyses were performed by using SPSS (IBM SPSS statistics; version 21.0, Armonk, NY, USA). P-values $\leq 0.05$ were considered statistically significant. 


\section{Results}

During the study period, 704 patients were recalled from the national breast cancer screening program and visited our institute for further analysis. Of these, 147 women were recalled from screening for suspicious calcifications (mean age 60.5 years, range 49-75). Final pathology showed 82 benign and 65 malignant lesions, of which 33 DCIS lesions and 32 invasive lesions were diagnosed. A detailed overview of patient inclusion and final histopathological diagnosis is presented in Figure 1.

Diagnostic performance parameters for the assessment of breast calcifications on the LE images were: sensitivity 90.8\% (59/65), specificity 39\% (32/82), PPV 54.1\% (59/109) and NPV 84.2\% (32/38). For the entire CEM, sensitivity was $93.8 \%$ (61/65), specificity $36.6 \%$ (32/82), PPV 54\% (61/113) and NPV 88.2\% (30/34). Table 1 shows a detailed overview of the diagnostic performance parameters, including the $95 \%$ confidence intervals and absolute numbers of true positive, false negative, false positive and true negative test results.

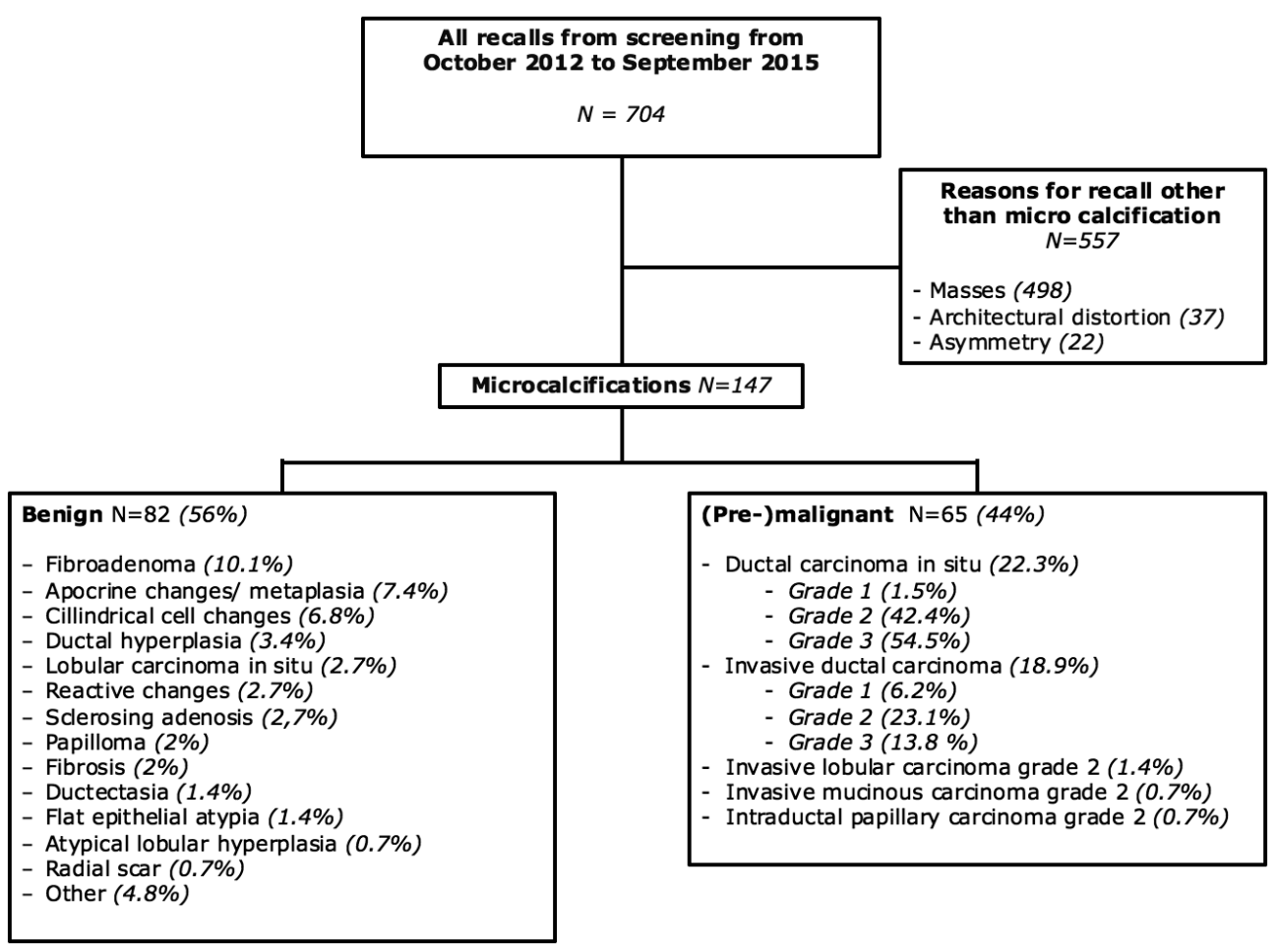

Figure 1. Flowchart of patient selection and final diagnosis. 


\begin{tabular}{|l|l|l|}
\hline Performance & LE $(95 \% \mathrm{CI})$ & CEM $(95 \% \mathrm{CI})$ \\
\hline Sensitivity & $90.8 \%(81.0-96.6 \%)$ & $93.8 \%(85.0-98.3 \%)$ \\
\hline Specificity & $39.0 \%(28.4-50.4 \%)$ & $36.6 \%(26.2-48.0 \%)$ \\
\hline Positive predicted value & $54.1 \%(49.4-58.8 \%)$ & $54.0 \%(49.6-58.3 \%)$ \\
\hline Negative predicted value & $84.2 \%(70.4-92.3 \%)$ & $88.2 \%(73.6-95.3 \%)$ \\
\hline Mean diameter (PCC) & $0.91(0.805)$ & $3.56(0.785)$ \\
\hline Performance - Absolute numbers (n= 147$)$ & LE & CEM \\
\hline True positive & 59 & 61 \\
\hline True negative & 32 & 30 \\
\hline False positive & 50 & 52 \\
\hline False negative & 6 & 4.492 \\
\hline Bland Altman plot & 0.2615 & -27.276 \\
\hline Mean & -39.142 & CEM \\
\hline LOA upper & 665 & 56.261 \\
\hline LOA lower & 52 & \\
\hline
\end{tabular}

Table 1. Detailed overview of the diagnostic performance. Abbreviations: Confidence interval (CI), Pearson's correlation coefficient (PCC), limits of agreement (LOA) 
Mean diameter of all malignant and in situ lesions was $29.4 \mathrm{~mm}$ (standard deviation $27.3 \mathrm{~mm}$ ). When comparing tumor size measurements as assessed by the radiologist on the LE and CEM images versus histopathological size diameter, the mean difference was $0.3 \mathrm{~mm}(95 \% \mathrm{LOA}$ 39.1 to $+39.7 \mathrm{~mm}$ ) for LE and $4.5 \mathrm{~mm}(95 \% \mathrm{LOA}-27.3$ to $+36.3 \mathrm{~mm})$ for CEM, (Figure 2).
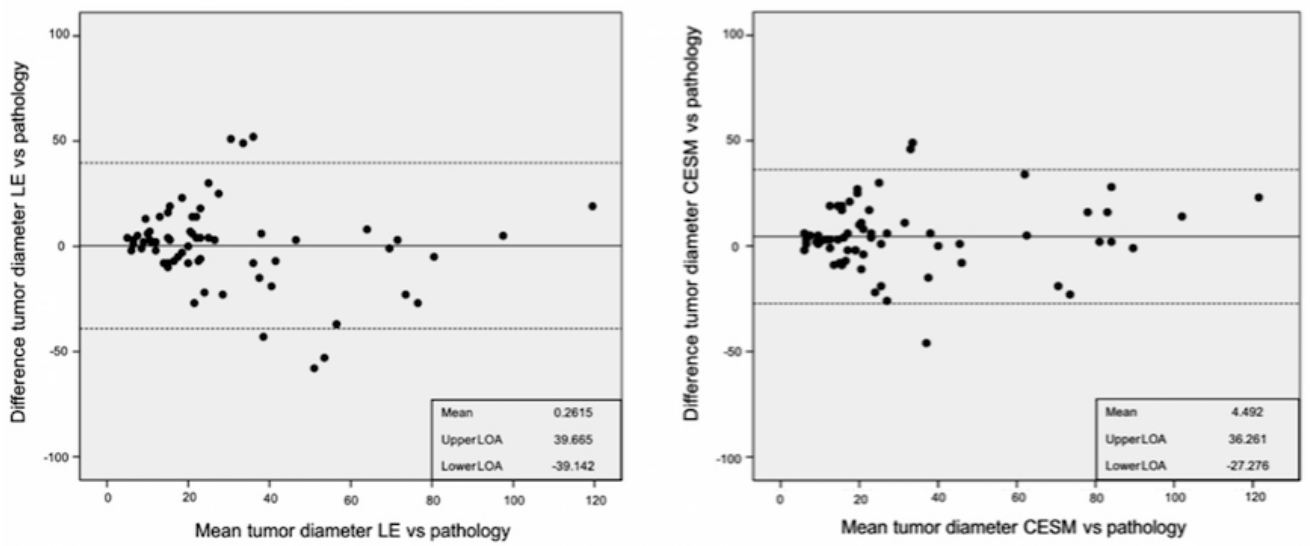

Figure 2. Bland Altman plots visualizing the discrepancies between maximum tumor size measurements according to histopathological examination (gold standard) and maximum tumor size measurements on imaging. The left panel shows results for low-energy (LE) images and the right panel the discrepancies for the entire CEM exam. Also presented are the mean discrepancy (in $\mathrm{mm}$ ) with histopathological measurements and the upper and lower 95\% limits of agreement (LOA). 
These findings imply that $95 \%$ of size measurements on LE imaging lie within a range between $3.9 \mathrm{~cm}$ below and $4 \mathrm{~cm}$ above the true size (as measured in histopathological specimens). For CEM, the random measurement errors are slightly smaller, with $95 \%$ of size measurements situated in a range between $2.7 \mathrm{~cm}$ below or $3.6 \mathrm{~cm}$ above the true size. The higher mean difference for CEM indicates that CEM tends to slight overestimation of size. Accurate assessment of disease extent is important for surgical management decision. An alternation in diameter occurred in 51/65 (78.4\%) cases, in which we observed a mean difference of $4.23 \mathrm{~mm}$ $(-32 \mathrm{~mm}-+60 \mathrm{~mm})$. The PCC for LE was $0.700, \mathrm{p}<0.001$, and for CEM 0.835, $\mathrm{p}<0.001$.

Off all invasive breast cancers, 84.4\% showed enhancement (27/32), whereas enhancement was observed in $81.1 \%$ of the pure DCIS lesions (27/33). In these latter cases, enhancement was observed in $88.9 \%(16 / 18)$ of the high-grade DCIS, $71.4 \%(10 / 14)$ in the intermediate grade and $100 \%(1 / 1)$ in the low-grade DCIS. The five non-enhanced invasive breast cancers mean size is $23.7 \mathrm{~mm}$ with a range of $5-62 \mathrm{~mm}$. For the six non-enhanced DCIS lesions the mean size was $23 \mathrm{~mm}$ with a range $8-40 \mathrm{~mm}$.

Based on all available clinical information and the LE images, the surgeons recommended breast conservative treatment (BCT) as the optimal surgical strategy in 58 cases (89.2\%), with the remaining cases recommended to undergo primary mastectomy. In the second session, where their decision was based on all information including the entire CEM exam, they recommended to perform BCT in 55 cases (84.6\%). Decisions were concordant in 58 of 65 patients and discordant in 7 patients. These differences were not statistically significant $(p=0.453)$. Based on the entire CEM exam, five cases were recommended to undergo mastectomy instead of BCT, whereas two cases were recommended to downsize surgery to BCT instead of mastectomy. Two examples of using CEM to evaluate suspicious breast calcifications were presented in Figures 3 and 4. 

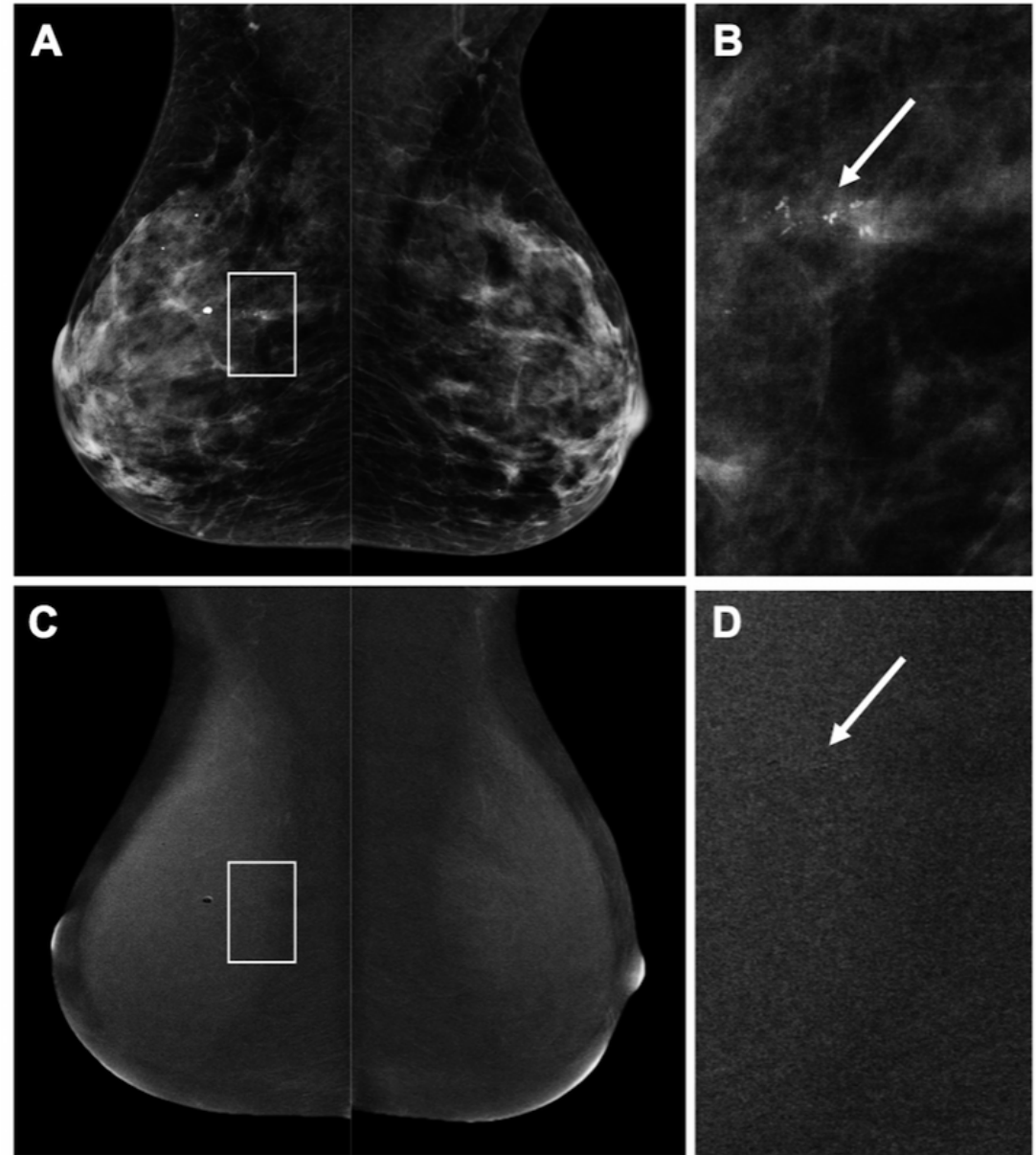

Figure 3. 50-year old patient who was recalled for suspicious breast calcifications. Figure A shows the low-energy images of the subsequent CEM exam that was performed, with a detailed view of the calcifications in B (arrow). On the recombined images (C), no abnormal enhancement was seen in the area of the calcifications, that appear as black on the detailed recombined image (D, arrow). Final histopathological results revealed a $20 \mathrm{~mm}$ DCIS grade 2. 

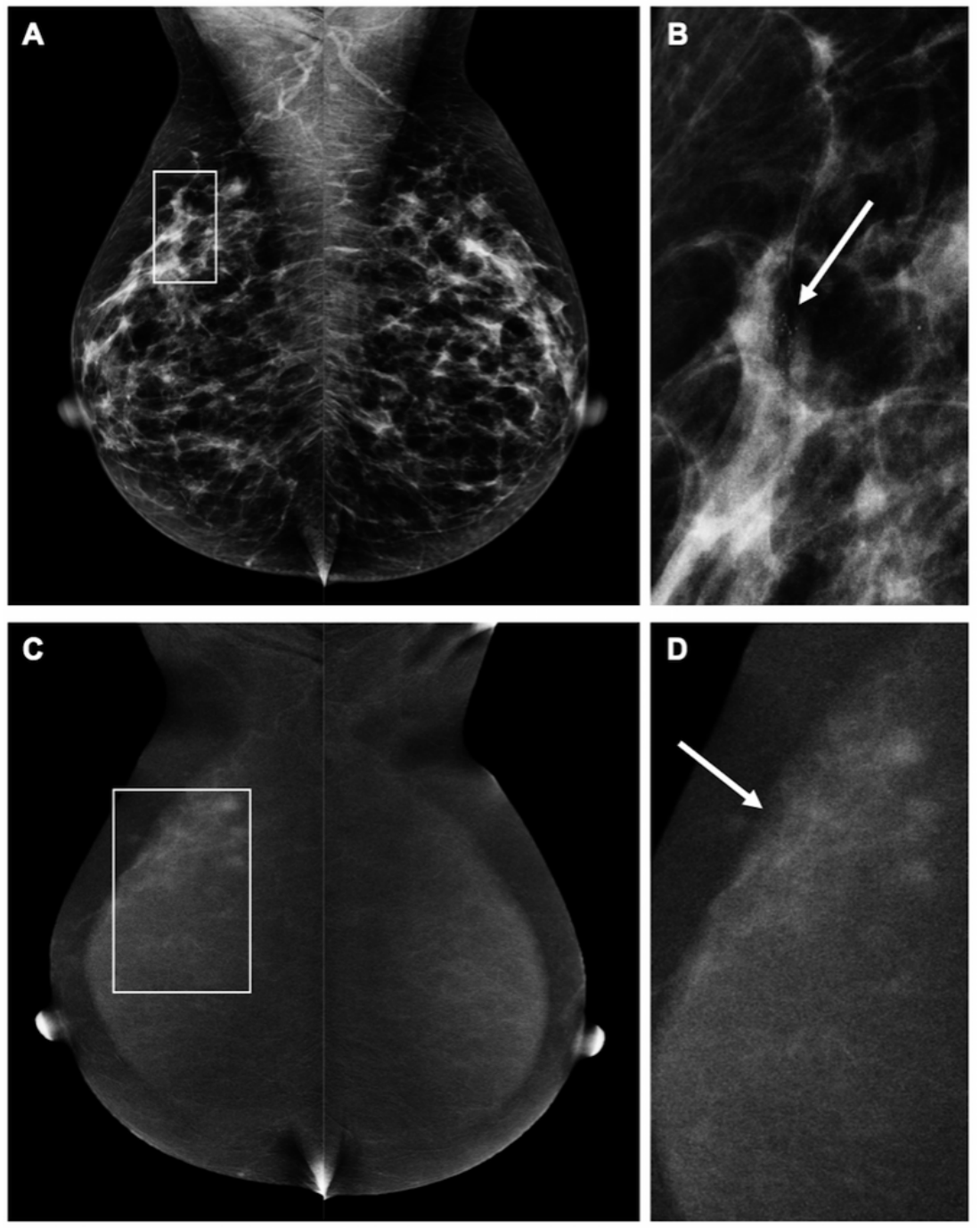

Figure 4. Example of a 52-year old patient recalled for suspicious breast calcifications in the right breast. Figure A shows the low-energy images with a detailed view of the calcifications in Figure B (arrow). After contrast administration, the recombined images (C) show an area of segmental non mass enhancement, showing that the true disease extent is much larger than was initially suspected on conventional mammography (Figure D, arrow). Final histopathological results revealed a small invasive ductal carcinoma $(6 \mathrm{~mm})$ surrounded by DCIS grade 2 (40 $\mathrm{mm}$ ). 


\section{Discussion}

In theory, CEM can evaluate suspicious breast calcifications more accurately, as it combines the high spatial resolution and excellent visibility of suspicious calcifications using mammography with information on lesion vascularity. Therefore, we aimed to assess the diagnostic accuracy of CEM in breast calcifications and studied whether the use of CEM could result in improved surgical decision making. We observed an only slight improvement in sensitivity and NPV at the predefined cut-off point. Measurement error in the assessment of disease extent is slightly reduced when using CEM, although CEM tends to slightly overestimate disease extent. Observed changes were minute and proved to have no significant impact on surgical decision making.

Studies have shown that CEM is superior to FFDM in overall performance. In a recent systematic review covering 920 patients (eight studies), the estimated sensitivity of CEM was $98 \%$ (95\% CI 96-100\%), with a reported estimated specificity of 58\% (95\% CI 38-77\%). ${ }^{11}$ The moderate specificity might be explained by the preponderance of data ( 3 of the 8 studies selected) from one study group. This group cited only a FFDM specificity of $15 \%$, questioning the validity of results, showing a CEM specificity of only $40 \%$. Jochelson et al. performed a recalculation of results using the other cited papers, resulting in an estimated CEM specificity of $78 \%$ (95\% CI 56-90\%). ${ }^{23}$ However, most studies focused on the entire spectrum of breast lesions, not only on one specific subtype such as suspicious calcifications.

To the best of our knowledge, only two papers studied the diagnostic performance of CEM in calcifications. These were both by Cheung et al. and showed a significant overlap in the inclusion period (52 patients enrolled from February 2012 until December 2013 ${ }^{24}$, versus 94 patients from February 2012 until June 2015. ${ }^{25}$

Consequently, we compared our results to the largest study by Cheung et al. ${ }^{25}$ In this study, sensitivity was $89 \%$, specificity $87 \%$, PPV $77 \%$ and NPV 95\%. Thus, cancer detection rates are in line with our observations, but their false positive rates are much lower, as expressed in a superior specificity and PPV when compared to our study. 
In our study, sensitivity of detecting breast cancer or DCIS was similar for LE and CEM in patients with a malignant lesion according to the gold standard. However, with the use of CEM a BI-RADS score of 5 was assigned more frequently than scores $4 a / 4 b / 4 c(66.2 \%$ versus $27.6 \%$ ). When using only LE, these percentages were $16.9 \%$ and $73.8 \%$, respectively. This substantial shift towards a higher frequency BI-RADS 5 (from $4 \mathrm{a} / 4 \mathrm{~b} / 4 \mathrm{c}$ ) indicates that CEM provides the reader with more confidence that the observed suspicious calcifications represent DCIS or breast cancer. But since the predefined cut-off to differentiate between benign lesions and malignant ones was $\geq 4$, this did not result in a more pronounced improvement in diagnostic accuracy parameters.

With respect to enhancement of suspicious breast calcifications, we did not observe any relevant differences between the amount of enhancement between invasive or in situ breast cancers. Consequently, CEM cannot be used to distinguish between these two if one would opt to study a more 'wait-and-see' approach for pure DCIS. In addition, we did not observe any relevant differences between different grades of pure DCIS: the only low-grade DCIS in this study showed enhancement, whereas approximately $11 \%$ of the high-grade DCIS did not show any enhancement. Hence, CEM cannot be used to distinguish between different grades of DCIS, especially low grade versus high grade DCIS.

We observed that invasive and non-invasive cancer show no enhancement in a comparable proportion. In theory, the numbers of invasive cancers showing no enhancement should be low, as they normally have access to blood and lymphatic vessels.

However, our group of invasive cancers without any enhancement is too low to draw any definite conclusions $(\mathrm{N}=5)$. Nevertheless, the amount of enhancement might hold important diagnostic information which should be studied in larger populations, especially since methods for assessing enhancement quantitatively have recently been published. ${ }^{26} 27$

In this study, we did not perform any magnification views as added view to evaluate calcifications. In the current digital era, electronic magnification ('zooming') can be used to assess breast calcifications in detail. In a previous study by Fallenberg et al. it was nevertheless shown that even then dedicated magnification views improve the visibility of calcifications (AUC value 0.664 for mammography vs. 0.813 for mammography plus magnification views), but the sample size of 100 cases is rather small. However, the AUC value of 0.813 is still not high enough to refrain from any tissue sampling. 
In other words, if calcifications are deemed 'suspicious' on full-field digital mammography, adding magnification views only visualizes the calcifications better, but the indication for performing a (stereotactic) biopsy will remain. ${ }^{28}$

With respect to the assessment of disease extent, Cheung et al. observed a better agreement between measurement performed on CEM compared to FFDM (with histopathology as gold standard). For FFDM, the mean difference was $4.2 \mathrm{~mm}$, whereas for CEM it was $0.5 \mathrm{~mm} .^{24}$ However, these differences in both studies are relatively small and presumably of no impact on surgical decision making, as the breast surgeon will consider an oncological safe margin $(<4 \mathrm{~mm})$ surrounding the calcifications anyway. ${ }^{8}$ This was the main reason why we decided to also consider the impact of the findings on surgical decision making, as this is the study outcome that is most relevant when assessing disease extent. As might be expected based on these results, there were no statistically significant differences between the surgical treatment plans based on the LE images or the entire CEM exam.

Our study has some limitations. First, the study was retrospective in design with a limited sample size (although this is the largest study on this topic so far to the best of our knowledge). Diagnostic performance of the reader did not show a significant increase in sensitivity and specificity at the pre-defined cut-off value when using the entire CEM exam. Second, surgical decision making was based on documented patient information and presentation of imaging findings to simulate a multidisciplinary tumor board meeting as accurately as possible. This did not allow the surgeons to perform physical examination and explore patient preferences or history, which is mandatory to optimize the surgical decision making process, especially with respect to continuously evolving oncoplastic surgical approaches. Furthermore, we opted to perform a simulated MDT meeting due to the retrospective nature of this study. Therefore, an objective evaluation of the impact of CEM on surgical outcome (in terms of radical surgery) was not possible. Although the simulated MDT might reach the same conclusion regarding proposed surgical strategy, the patient's preference could lead to an alternative surgery. Hence, a prospective randomized controlled clinical trial studying the impact of either FFDM or CEM on surgical outcome would be needed. However, in this retrospective study design, this evaluation simulated daily clinical practice as closely as possible. Third, the population of patients represents a selected group recalled from a national screening program, wherein screening radiologists decide whether an abnormality should be recalled. 
In theory, a different set of patients could be selected if other radiologists would read the same exams. However, this is current practice in our breast cancer screening program. Fourth, this was a single reader study, albeit with an experienced breast radiologist. This refrained us from studying inter-observer variation in the evaluation of suspicious calcifications using CEM.

\section{Conclusion}

The results of our study showed that CEM resulted in an only minute improvement in sensitivity and NPV at the predefined cut-off point, with the measurement error in the assessment of disease extent being slightly reduced compared to FFDM. However, these small changes did not seem to have a relevant impact on surgical decision making. 


\section{References}

1. Weber RJ, Nederend J, Voogd AC, et al. Screening outcome and surgical treatment during and after the transition from screen-film to digital screening mammography in the south of The Netherlands. Int $J$ Cancer 2015;137(1):135-43. doi: 10.1002/ijc.29354 [published Online First: 2014/11/25]

2. Liberman L, Abramson AF, Squires FB, et al. The breast imaging reporting and data system: positive predictive value of mammographic features and final assessment categories. AJR Am J Roentgenol 1998;171(1):35-40. doi: 10.2214/ajr.171.1.9648759 [published Online First: 1998/07/02]

3. Cosar ZS, Cetin M, Tepe TK, et al. Concordance of mammographic classifications of microcalcifications in breast cancer diagnosis: Utility of the Breast Imaging Reporting and Data System (fourth edition). Clin Imaging 2005;29(6):389-95. doi: 10.1016/j.clinimag.2005.05.002 [published Online First: 2005/11/09]

4. Burnside ES, Ochsner JE, Fowler KJ, et al. Use of microcalcification descriptors in BIRADS 4th edition to stratify risk of malignancy. Radiology 2007;242(2):388-95. doi: 10.1148/radiol.2422052130 [published Online First: 2007/01/27]

5. Bent CK, Bassett LW, D'Orsi CJ, et al. The positive predictive value of BI-RADS microcalcification descriptors and final assessment categories. AJR Am J Roentgenol 2010;194(5):1378-83. doi: 10.2214/AJR.09.3423 [published Online First: 2010/04/23]

6. Kim SY, Kim HY, Kim EK, et al. Evaluation of malignancy risk stratification of microcalcifications detected on mammography: a study based on the 5th edition of BIRADS. Ann Surg Oncol 2015;22(9):2895-901. doi: 10.1245/s10434-014-4362-6 [published Online First: 2015/01/23]

7. van Esser S, Peters NH, van den Bosch MA, et al. Surgical outcome of patients with corebiopsy-proven nonpalpable breast carcinoma: a large cohort follow-up study. Ann Surg Oncol 2009;16(8):2252-8. doi: 10.1245/s10434-009-0513-6 [published Online First: 2009/05/14]

8. Lobbes MB, Vriens IJ, van Bommel AC, et al. Breast MRI increases the number of mastectomies for ductal cancers, but decreases them for lobular cancers. Breast Cancer Res Treat 2017;162(2):353-64. doi: 10.1007/s10549-017-4117-8 [published Online First: 2017/01/31] 
9. Gruber IV, Rueckert M, Kagan KO, et al. Measurement of tumour size with mammography, sonography and magnetic resonance imaging as compared to histological tumour size in primary breast cancer. BMC Cancer 2013;13:328. doi: 10.1186/1471-2407-13-328 [published Online First: 2013/07/06]

10. Fancellu A, Turner RM, Dixon JM, et al. Meta-analysis of the effect of preoperative breast MRI on the surgical management of ductal carcinoma in situ. $\mathrm{Br} J$ Surg 2015;102(8):883-93. doi: 10.1002/bjs.9797 [published Online First: 2015/04/29]

11. Tagliafico AS, Bignotti B, Rossi F, et al. Diagnostic performance of contrast-enhanced spectral mammography: Systematic review and meta-analysis. Breast 2016;28:13-9. doi: 10.1016/j.breast.2016.04.008 [published Online First: 2016/05/11]

12. Tennant SL, James JJ, Cornford EJ, et al. Contrast-enhanced spectral mammography improves diagnostic accuracy in the symptomatic setting. Clin Radiol 2016;71(11):1148-55. doi: 10.1016/j.crad.2016.05.009 [published Online First: 2016/06/15]

13. Jochelson MS, Pinker K, Dershaw DD, et al. Comparison of screening CEDM and MRI for women at increased risk for breast cancer: A pilot study. Eur J Radiol 2017;97:3743. doi: 10.1016/j.ejrad.2017.10.001 [published Online First: 2017/11/21]

14. Lalji UC, Houben IP, Prevos R, et al. Contrast-enhanced spectral mammography in recalls from the Dutch breast cancer screening program: validation of results in a large multireader, multicase study. Eur Radiol 2016;26(12):4371-79. doi: 10.1007/s00330016-4336-0 [published Online First: 2016/04/22]

15. Luczynska E, Heinze S, Adamczyk A, et al. Comparison of the Mammography, ContrastEnhanced Spectral Mammography and Ultrasonography in a Group of 116 patients. Anticancer Res 2016;36(8):4359-66. [published Online First: 2016/07/29]

16. Lalji UC, Jeukens CR, Houben IP, et al. Evaluation of low-energy contrast-enhanced spectral mammography images by comparing them to full-field digital mammography using EUREF image quality criteria. Eur Radiol 2015;25(10):2813-20. doi: 10.1007/s00330-015-3695-2 [published Online First: 2015/03/31]

17. Fallenberg EM, Dromain C, Diekmann F, et al. Contrast-enhanced spectral mammography versus MRI: Initial results in the detection of breast cancer and assessment of tumour size. Eur Radiol 2014;24(1):256-64. doi: 10.1007/s00330-013-3007-7 [published Online First: 2013/09/21] 
18. Lobbes MB, Lalji UC, Nelemans PJ, et al. The quality of tumor size assessment by contrastenhanced spectral mammography and the benefit of additional breast MRI. $J$ Cancer 2015;6(2):144-50. doi: 10.7150/jca.10705 [published Online First: 2015/01/07]

19. Lobbes MB, Lalji UC, Houwers J, et al. Contrast-enhanced spectral mammography in patients referred from the breast cancer screening programme. Eur Radiol 2014;24(7):1668-76. doi: 10.1007/s00330-014-3154-5 [published Online First: 2014/04/04]

20. Sickles E.A. Basset L.W., et al. Breast Imaging Reporting and Data System. ACR BIRADS mammography Atlas: American College of Radiology 2013.

21. NABON. National guideline breast cancer. In: (NABON) NBON, ed. Amsterdam, 2012.

22. Robin X, Turck N, Hainard A, et al. pROC: an open-source package for R and S+ to analyze and compare ROC curves. BMC Bioinformatics 2011;12:77. doi: 10.1186/1471-210512-77 [published Online First: 2011/03/19]

23. Jochelson M, Lobbes MBI, Bernard-Davila B. Reply to Tagliafico AS, Bignotti B, Rossi F, et al. Breast 2017;32:267. doi: 10.1016/j.breast.2016.10.017 [published Online First: 2016/12/29]

24. Cheung YC, Tsai HP, Lo YF, et al. Clinical utility of dual-energy contrast-enhanced spectral mammography for breast microcalcifications without associated mass: a preliminary analysis. Eur Radiol 2016;26(4):1082-9. doi: 10.1007/s00330-015-3904-z [published Online First: 2015/07/15]

25. Cheung YC, Juan YH, Lin YC, et al. Dual-Energy Contrast-Enhanced Spectral Mammography: Enhancement Analysis on BI-RADS 4 Non-Mass Microcalcifications in Screened Women. PLoS One 2016;11(9):e0162740. doi: 10.1371/journal.pone.0162740 [published Online First: 2016/09/10]

26. Deng CY, Juan YH, Cheung YC, et al. Quantitative analysis of enhanced malignant and benign lesions on contrast-enhanced spectral mammography. $\mathrm{Br} J$ Radiol 2018;91(1086):20170605. doi: 10.1259/bjr.20170605 [published Online First: 2018/02/17]

27. Hwang YS, Cheung YC, Lin YY, et al. Susceptibility of iodine concentration map of dualenergy contrast-enhanced digital mammography for quantitative and tumor enhancement assessment. Acta Radiol 2018;59(8):893-901. doi: 10.1177/0284185117740760 [published Online First: 2017/11/10] 
28. Fallenberg EM, Dimitrijevic L, Diekmann F, et al. Impact of magnification views on the characterization of microcalcifications in digital mammography. Rofo 2014;186(3):274-80. doi: 10.1055/s-0033-1350572 [published Online First: 2013/09/04] 



\section{Chapter 6}

Rapid Access to Contrast-Enhanced spectral mammogRaphy in women recalled from breast cancer screening: the RACER trial study design.

L.M.F.H. Neeter, I.P.L. Houben, P.J. Nelemans, T.J.A. van Nijnatten, R.M. Pijnappel, C. Frotscher, M. Osinga-de Jong, F. Sanders, T. van Dalen, H.P.J. Raat, B.A.B. Essers, J.E. Wildberger, M.L. Smidt, M.B.I. Lobbes

Trials, 2019. 20(1), 759. 



\section{Abstract}

Background - In the Dutch breast cancer screening program, women recalled with a BIRADS 0 score are referred for additional imaging, while BI-RADS 4/5 scores are also directed to an outpatient breast clinic. Approximately six out of ten women are recalled without being diagnosed with a malignancy. However, these recalls require additional imaging and doctor visits, which result in patient anxiety and increased health care costs. Conventional imaging used for additional imaging are full-field digital mammography and tomosynthesis. ContrastEnhanced Spectral Mammography has proved to have higher sensitivity and specificity than conventional imaging in women recalled from screening. Therefore, the aim is to study if CESM instead of conventional imaging is a more accurate, more patient friendly and more cost-effective strategy in the work-up of women recalled from breast cancer screening.

Methods - This prospective, multicenter, randomized controlled trial will be conducted at four centers and will include 528 patients recalled for suspicious breast lesions from the Dutch breast cancer screening program. Participants are randomized in two groups: (1) standard care using conventional breast imaging techniques as initial imaging after recall versus (2) work-up primarily based on CESM. Written informed consent will be collected prior to study inclusion. The primary outcome is the diagnostic accuracy for detection of breast cancer. Secondary outcomes are numbers of additional diagnostic exams, days until final diagnosis, healthcare costs, and experienced patient anxiety.

Discussion - Based on previously published retrospective studies, we expect to demonstrate in this prospective multicenter randomized controlled trial, that using CESM as a primary work-up tool in women recalled from breast cancer screening is a more accurate, more costeffective and a more patient-friendly strategy. 


\section{Background}

In the Netherlands, a national breast cancer screening program was introduced in 1990, with full implementation being completed in 1997. All women aged 50-75 years receive an invitation to participate biennially. At mobile screening units, full-field digital mammography (FFDM) is performed. By default, two images are made per breast, one in cranio-caudal (CC) view and one in mediolateral oblique (MLO) view. The images are independently screened for suspicious lesions by two certified screening radiologists. In the case of discrepancy, a third (senior and unblinded) radiologist will make the final decision regarding referral. In the screening recalls, a distinction is made between BI-RADS 0 score and BI-RADS 4 or 5 score recalls. ${ }^{1}$ Women recalled with a BI-RADS 0 score are directly referred by their general physician (GP) for additional imaging. Women recalled with BI-RADS 4 or 5 score are first referred by their GP to an outpatient breast clinic, before being directed to a Radiology department for additional imaging. ${ }^{2}$

Conventional additional imaging may consist of additional (special) FFDM images or digital breast tomosynthesis (DBT), which can be combined with other imaging modalities, such as breast ultrasound (US). Based on the findings during imaging work-up, tissue sampling might be recommended: either core needle biopsy (CNB), vacuum-assisted biopsy (VAB), or fineneedle aspiration cytology (FNAC). The total work-up in the evaluation of the recalled women can also be extended with breast magnetic resonance imaging (MRI) (e.g., in inconclusive findings) or six and/or twelve -months follow-up with FFDM, DBT and/or US.

Approximately six out of ten recalled women from the Dutch breast screening program are not diagnosed with breast cancer. ${ }^{3}$ These recalls generate patient distress and anxiety as well as additional doctor visits, medical imaging, and health care costs. ${ }^{3-5}$ Also, participation rates for subsequent screening rounds decrease after a recall of women without malignancy. ${ }^{6}$

Prior retrospective studies have shown that for these women contrast-enhanced spectral mammography (CESM) proved to be an adequate problem-solving tool, reducing the number of false positives while maintaining high sensitivity. ${ }^{35}$ Hypothetically, the use of CESM as an imaging work-up in women recalled from screening reduces the number of additional imaging exams and follow-up doctor visits, potentially saving health care costs. ${ }^{7}$ 
Especially for women with dense breasts, CESM seems to be of additional value, since these women are more at risk of undergoing additional imaging or follow-up after recall due to the low sensitivity of FFDM. ${ }^{8}{ }^{9}$ Moreover, Houben et al. showed that occult breast cancers are detected when using CESM in up to $4 \%$ of women in this population, increasing overall accuracy. ${ }^{10}$

Therefore, we propose a prospective, multicenter, randomized, controlled trial, aiming to study whether work-up using CESM instead of conventional imaging modalities such as FFDM or DBT (which is the current standard of care) for women recalled from screening is a more accurate, more patient-friendly and more cost-effective strategy. 


\section{Methods}

The RACER study is a multicenter, prospective, randomized controlled clinical trial. Participants will be randomized in two study arms: (1) a control group undergoing standard care, i.e., work-up of recalled women based on conventional imaging (such as FFDM, US, DBT or MRI) versus (2) work-up primarily based on CESM findings. The follow-up period is two years, until the next screening round. Four centers will participate in patient inclusion: the coordinating center Maastricht University Medical Center+ (Maastricht), Zuyderland Medical Center (Sittard-Geleen), Diakonessenhuis (Utrecht) and Laurentius Hospital (Roermond). The study is coordinated (study design, protocol, trial master file, case report forms and ethical approval) by the research team in Maastricht including the Principal Investigator and Study Coordinator. Each center has a breast radiologist or surgeon as lead investigator and is assisted by other radiologists and technicians in that center for patient inclusion with randomization. Training of new research team members will be done by the Study Coordinator. The Study Coordinator also assists with and is responsible for correct data entry in all centers. Central ethical approval has been confirmed from the Medical Research Ethics Committee of University hospital Maastricht and Maastricht University (decision no. METC171082/NL62788.068.17) and we will not begin recruiting at other centers in the trial until local ethical approval has been obtained.

A data management system with electronic case report forms (eCRFs) is used to manage the clinical data of the participants in anonymous form by their trial identification number. No biological specimen will be collected in this trial. Data entry, access and storage is restricted to the research teams and this is monitored. Auditing, including site visits, will take place by the Clinical Trial Center Maastricht (CTCM) at each center, before, during and at the end of the study. Since this study is marked as 'low risk study' by the CTCM, a data monitoring committee is not commissioned. Interim analysis and premature termination of the study are not applicable; however, periodic trial progress reports are requested by the main funders of the study. After completion of the study, each center will store all their study data for 15 years. 


\section{Study population}

All women recalled for a suspicious breast lesion from our national screening program are eligible for inclusion. Inclusion criteria are the ability to provide written informed consent and being recalled from breast cancer screening during the 18-month study inclusion period. Excluded are women with a known allergy to iodine-based contrast agents and women at risk for developing contrast-induced nephropathy or women with known renal insufficiency, according to the current guidelines.

\section{Primary and secondary outcomes}

The primary outcome will be the accuracy assessed by diagnostic performance parameters, such as sensitivity, specificity, Positive Predictive Value (PPV), Negative Predictive Value (NPV), Receiver Operating Characteristics curve (ROC curve) and Area Under the Curve (AUC). Radiologists will prospectively provide a single BI-RADS classification for each exam, where a BI-RADS score of 1-3 will be considered 'benign' and 4-5 'malignant'. The final BI-RADS score (BI-RADS 1-5), based on imaging, will be compared with the BI-RADS score given by the screening program. The accuracy assessed by diagnostic performance parameters will be assessed after the next screening round after approximately two years.

Secondary outcomes will be quality of life, days until final diagnosis, cost-effectiveness and experienced patient anxiety during a follow-up of 18 months. Three validated questionnaires will be presented at six different time points (at study inclusion and after 2 and 4 weeks, and after 6,12 and 18 months). Quality of life (Qol) will be assessed by the Dutch version of the EuroQol five-dimension, five-level (EQ-5D-5L) questionnaire, including a visual analog scale (EQ-VAS) questionnaire. This questionnaire is a preference-based instrument used to value health states. ${ }^{11}$ The Dutch tariff for the EQ-5D-5L questionnaire, as established by Versteegh et al., will be used to calculate utility scores per health state. ${ }^{12}$ Then the Quality Adjusted Life Years (QALY) will be modeled based on these utility scores. Resource use related to diagnostics will be collected during the trial. 
Health-related anxiety, both state and trait anxiety, will be measured by the Dutch version of the State Trait Anxiety Inventory (STAI-DY-1 and STAI-DY-2) questionnaires. Each STAI has 20 items and will be rated on a 4-point Likert scale, scoring 20-80 points per STAI. A higher score corresponds to a higher anxiety level. ${ }^{13}$

For the Qol and STAI scores, inter- and intra-patient differences over time from baseline will be compared including those between the intervention and control group. The scores will also be compared between the women with a follow-up exam after 6 or 12 months and those without this follow-up. Figure 1 shows the outcomes defined by the five outcome elements described by Saldanha et al. ${ }^{14}$

To reduce patient effort, the questionnaires are offered digitally, or by telephone, if desired by the participant. Data from the digital questionnaires is automatically stored in the data management system. 


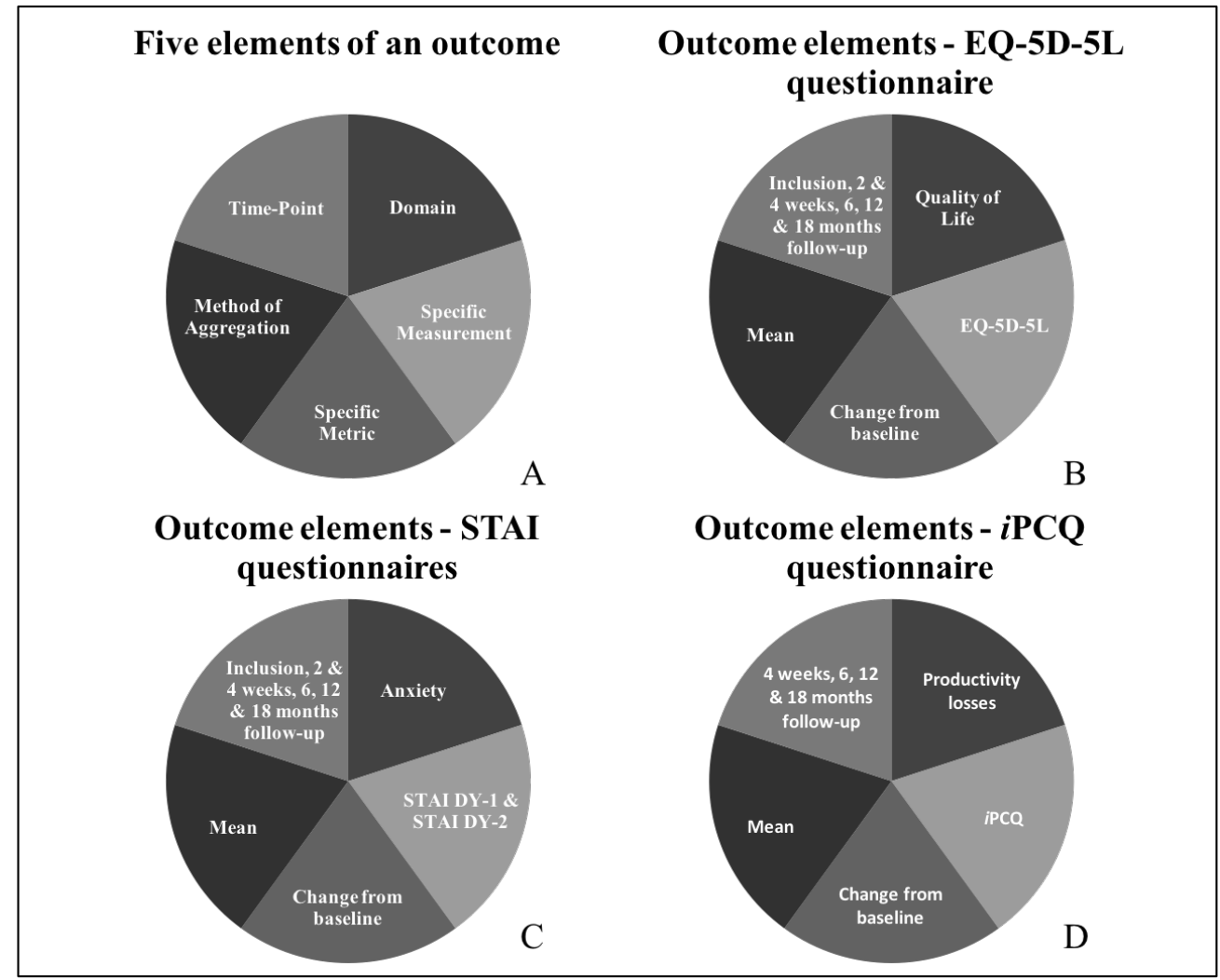

Figure 1. A: A schematic overview of an outcome specified in the five elements defined by Saldanha et al. ${ }^{14}$ B-D: Five elements of the outcome of respectively the EQ-5D-5L, STAI and iPCQ questionnaires. 


\section{Informed consent and randomization protocol}

All recalled women announced at one of the participating centers will be contacted for study participation. Written informed consent will be obtained first and the first EQ-5D-5L and STAI questionnaires regarding anxiety and current health state will be completed before any other study procedure is carried out. Participants are also asked for their consent to use their data in possible future studies. See Additional file 1 for the informed consent form in Dutch.

Women will be randomized to undergo standard of care (control arm) or CESM (intervention arm). Minimization with stratification factors will be applied in the computer-generated randomization screening and enrollment application software ALEA (version 3.0.2083.212r, ALEA Clinical, Abcoude, the Netherlands). Randomization will be stratified by the following: predominant reason for recall (mass, calcifications, asymmetry, architectural distortion), recall BI-RADS score (BI-RADS 0 versus BI-RADS 4/5), and study center. Enrollment in the four centers, including the master randomization file, will be overseen by the Study Coordinator. During the inclusion visit written consent will be conducted and data entry will be done by one of the research team members in each center to execute randomization using ALEA. Should a problem occur in including a patient or randomization, the Study Coordinator must be reached, so that he can provide assistance. After allocation, patient and radiologist will be informed about the outcome; hence, they are not blinded. However the radiologist is blinded for the outcomes between the two groups, since the final diagnosis and pathology are not yet known. The outcome assessors and data analysts are blinded for the judgment of the next screening round by the screening radiologists, since accuracy also depends on the next screening round outcome. Each participant is assigned a trial identification number for anonymization, to analyze the data, and further to be used in publications.

In each participant's hospital patient file a statement will be noted about study participation and the assigned intervention or control group. On request, study participation can be ended during the follow-up phase. 


\section{The control group: Usual care with conventional breast imaging}

Women undergoing standard of care will have their screening FFDM re-evaluated, adding (special) FFDM views, DBT, or US if deemed necessary. In FFDM and DBT, the breast is compressed between a paddle and detector plate. The laterality of the breast and views per breast depends on the judgment of the radiologist. At least one additional view of the recalled side will be performed. Tissue sampling (CNB, VAB, FNAC) can be recommended to support or to invalidate suspicious findings on imaging. In case of inconclusive findings, the radiologist can consider follow-up in six- and/or twelve-months, or single breast MRI. The use of CESM is not permitted in this study arm.

\section{The experimental group: Contrast-enhanced spectral mammography}

CESM is based on visualizing angiogenesis in tumour tissue using dual-energy mammography. ${ }^{15}$ Prior to image acquisition, an intravenous catheter will be placed in the antecubital vein, after which its patency will be checked by a saline test bolus. A non-ionic, low-osmolar contrast agent consisting of either iopromide (Ultravist ${ }^{\circledR}$ 300, Bayer Healthcare, Berlin, Germany) or iobitridol (Xenetix ${ }^{\circledR}$ 300, Guerbet, Villepinte, France) will be administered at a dose of $1.5 \mathrm{~mL} / \mathrm{kg}$ body weight. If an automatic injector is used instead of manual administration, the injection rate will be $2.5-3 \mathrm{~mL} / \mathrm{s}$, followed by a saline flush. Image acquisition is started after at least two minutes after contrast administration. ${ }^{16}$

Although there is a limited risk of complications, such as hematoma or incorrect catheter placement, a previous retrospective study showed that the risks of adverse reactions to the contrast agents and contrast-induced nephropathy are negligible. ${ }^{17}$ Two days after CESM, the patient file will be consulted to investigate whether any late (serious) adverse reactions to the contrast agent have occurred that needed medical treatment.

Similar to FFDM, the breasts are positioned between a mammography paddle and detector plate, and the four standard views are made: a cranio-caudal (CC) and mediolateral oblique (MLO) view of each breast. Special views can be requested by the reviewing radiologist. A typical CESM exam consists (per breast exposure) of two images: a low- and a high-energy image, which are acquired within seconds. ${ }^{18}$ These images are used in post-processing to acquire the recombined image, which shows areas of contrast accumulation (Figure 2). 
The CESM image acquisition needs to be completed within 10-12 minutes after contrast administration. ${ }^{19}$ As in the control group, tissue sampling, MRI and follow-up can be considered in case of inconclusive findings.

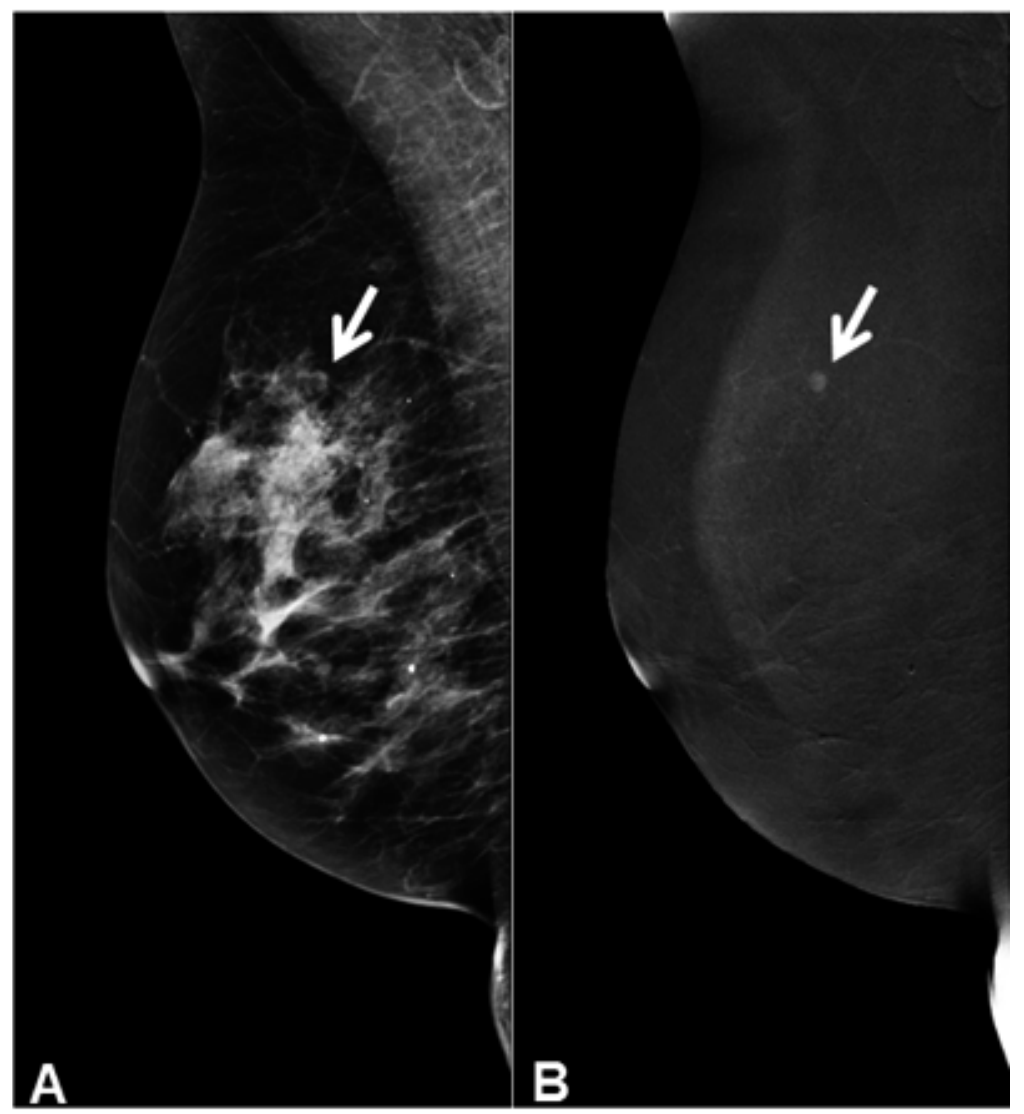

Figure 2. CESM image of right breast in MLO view. A: Low energy image, which is equivalent to FFDM image. B: Recombined image. The white arrows indicates the suspect mass which is only visible on the recombined image and not in the low energy image. The high energy image is not shown since it is not of clinical value. Histopathological findings showed grade I invasive carcinoma 
For the control group, final diagnoses of the (recalled) breast lesions can be divided into four categories $^{3}$ 5: (1) simple cysts; (2) superposition densities; (3) solid, benign masses; (4) (invasive) breast cancer or ductal carcinoma in situ (DCIS).

The first three groups are defined as benign findings. To ascertain a final diagnosis in (1), targeted US is performed, followed by cyst aspiration and a second FFDM of that breast to confirm that the lesion has disappeared. Final diagnosis of (2) requires a minimum of one special view or DBT, including targeted US. To rule out false negative (FN) findings, six and/or twelve-months follow-up or breast MRI can be considered. Final diagnosis for categories (3) and (4) is acquired with US-guided or stereotactic tissue sampling. If cancer or DCIS is diagnosed, the subject will have a be 'true positive' (TP) finding. In subjects where no breast cancer or DCIS is diagnosed, the follow-up period of two years will determine the true disease status. If no interval cancers have been detected and the subject has not been recalled in the subsequent screening round, the case will be considered 'true negative' (TN).

In the CESM group, diagnoses are acquired slightly different. For (1), CESM will show an 'eclipse sign' which is pathognomonic for cysts (3). No further action is needed. For category (2), a negative CESM exam with no suspect lesion on both low-energy and recombined images rules out (pre)malignant lesions due to CESM's high negative predictive value. ${ }^{35}$ To acquire final diagnoses of in (3) and (4), CESM and targeted US are performed including tissue sampling for pathological confirmation.

Since most benign recalls are caused by cysts or superposition densities, the investigated intervention will most likely result in fewer additional exams and tissue samplings among these recalls. ${ }^{35}$ Moreover, follow-up exams can be omitted, which is more patient friendly, and hypothetically, more women will attend the subsequent screening round when they are examined with CESM.

A flow chart is presented in Figure 3, summarizing the study design, the randomization process, and the establishment of the different diagnoses. 


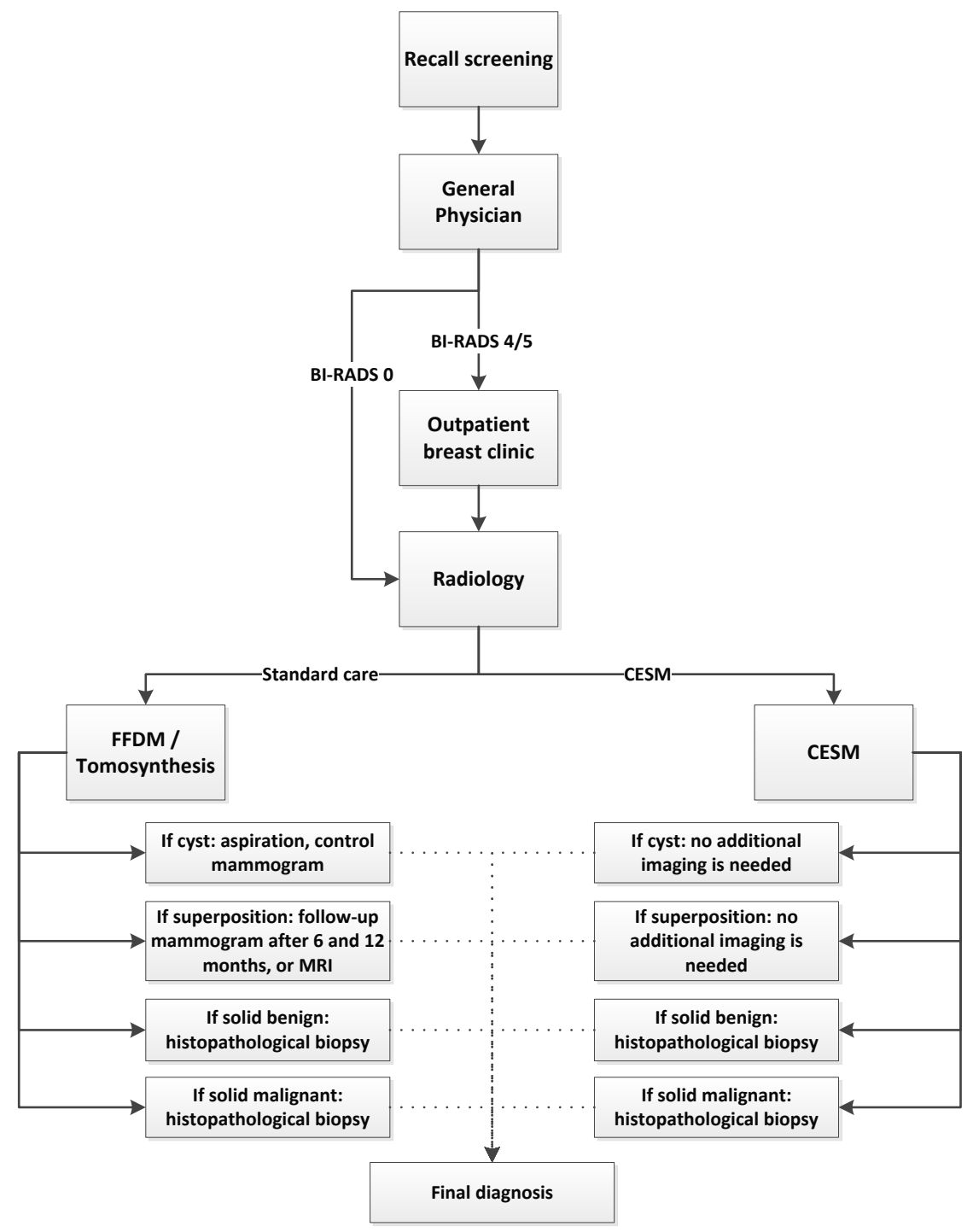

Figure 3. Work-up RACER study. Left arm: standard care group; Right arm: CEM group. 


\section{Sample size calculation}

Prior research showed a specificity of FFDM of $40 \%$ in this population. ${ }^{5}$ To enable detection of a clinically relevant increase of specificity by $15 \%$ (from $40 \%$ to $55 \%$ ), 176 patients without malignant disease per group are required (power $80 \%$, alpha $=5 \%$ ). The prevalence of malignant lesions in women recalled from the breast screening program is about $30 \%$, thus $70 \%$ have benign lesions. Therefore, a total of 251 women per group (176/0.7) has to be included. To account for $5 \%$ loss to-follow-up, the final number of patients to be included is $528(502 / 0.95)$. The Calculations were done with OpenEpi. ${ }^{20}$

\section{Statistical analysis}

The primary objective of the study is to demonstrate that the use of CESM as a work-up tool for women recalled from breast cancer screening is more accurate compared to standard care consisting of conventional imaging. The secondary objectives are to evaluate whether this novel approach is a more patient-friendly and cost-effective strategy in the work-up of women recalled from breast cancer screening, requiring fewer days until final diagnosis and less volumes of additional imaging.

Radiologists will prospectively provide a single BI-RADS classification for each exam, where a BI-RADS score of 1-3 will be considered 'benign' and $>4$ 'malignant'. Based on this cutoff, the final BI-RADS score and recall BI-RADS score, the diagnostic performance parameters sensitivity, specificity, PPV, NPV, and AUC under the ROC curve will be assessed as the primary endpoint for both study arms.

Differences in proportions between the two randomized groups will be tested for significance with a Chi-square test, and the difference in AUCs will be tested using the method proposed by Hanley et al. ${ }^{21}$

Secondary outcomes are QoL, patient anxiety, and cost-effectiveness. The course of scores on Qol with QALY and patient anxiety (STAI) from baseline over time at the six time points will be visualized and differences between groups will be tested using mixed linear models, which account for correlations between repeated measurements. Single and multiple imputation will be used to replace missing data. 
Both intention-to-treat and per protocol analyses will be performed. The per protocol population for the primary outcomes are those who got imaging exams based on their group allocation. Women who underwent CESM in the standard care group are excluded from the per protocol analysis. For the secondary outcomes this population can be further specified to those with questionnaires completed at six time points. P-values $<0.05$ will be considered to indicate statistical significance. Analyses will be performed with SPSS (version 25, IBM Corporation, Armonk, New York, USA) and STATA (version 15, StataCorp LCC, College Station, Texas, USA).

\section{Economic evaluation}

Decision-analytic modeling will be applied to estimate the cost-effectiveness of CESM compared to conventional imaging modalities FFDM or DBT for recalled women from the Dutch national screening program. The economic evaluation will be performed from both a health care and societal perspective. Cost-effectiveness will be expressed as the incremental costs per QALY gained as outcome measure. ${ }^{22}$ All resource use related to diagnostics will be registered. In addition, productivity loss will be measured with the iMTA Productivity Costs Questionnaire (iPCQ) at 4 weeks, and at 6, 12 and 18 months. ${ }^{23}$ Reference prices will be obtained from the Dutch manual for costing research, hospital financial department, or the literature. ${ }^{24}$ Uncertainty surrounding the incremental costs per QALY will be analyzed with non-parametric bootstrap analysis. ${ }^{25}$ Results of the bootstrap analysis will be presented in costeffectiveness planes and acceptability curves. A Probabilistic sensitivity analysis will be performed to examine different parameter uncertainties.

In Figure 4 an overview, according to Standard Protocol Items: Recommendations for Interventional Trials (SPIRIT), is given of all study activities, including the iPCQ assessments. 


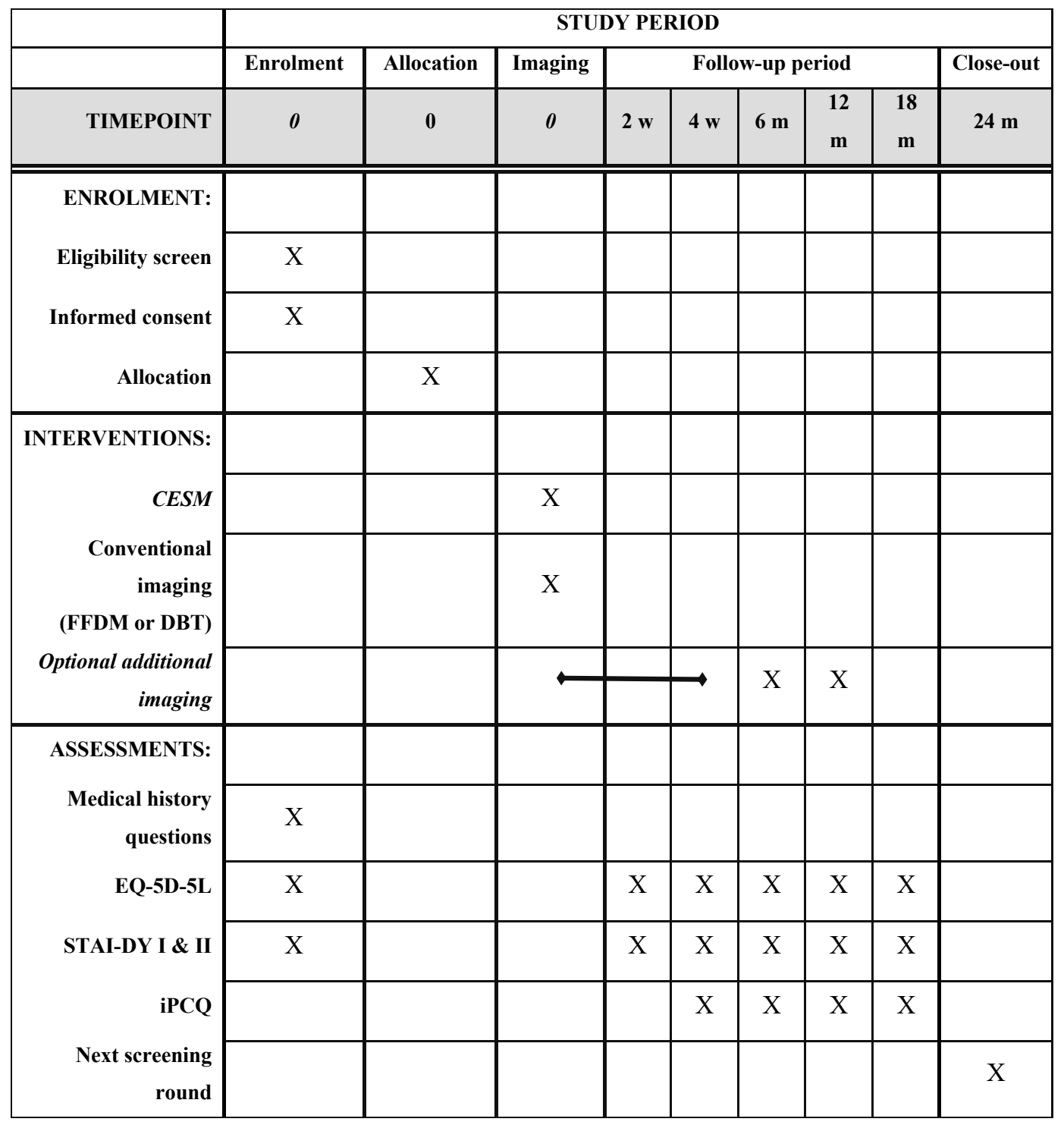

Figure 4. Schedule of study activities according to Standard Protocol Items: Recommendations for Interventional Trials (SPIRIT). 


\section{Discussion}

We present the rationale and design of the RACER study, which is a multicenter, prospective, randomized controlled trial investigating the work-up after breast cancer screening referral. This design is in accordance with the SPIRIT guidelines.

Recent studies have consistently shown that CESM is superior to FFDM, even when the latter is combined with targeted US. ${ }^{26-29}$ Lobbes et al. showed that in women recalled from screening, the detection of breast cancer was comparable between the two techniques, but specificity almost doubled from $42.0 \%$ to $87.7 \%$ when using CESM as a work-up tool. ${ }^{3}$ In other words, fewer false-positive findings were observed, and with the high negative predictive value of $97.1 \%$ in this study, there was a high ability to rule out breast cancer if the CESM showed a negative exam. These initial findings were later confirmed by Lalji et al. in 199 new cases, being analyzed by a panel of ten different radiologists. ${ }^{5}$ In this study, radiologists without any CESM experience (but with extensive experience in reading FFDM exams) performed as well as radiologists with CESM experience. Reading a CESM exam does not require a dedicated learning curve. Radiologists in the participating centers will have different levels of experience in reading CESM exams. However, these works used a retrospective study design. Also, many other studies on CESM are retrospective in nature. Only some studies collecting data prospectively, and most have not done so a randomized controlled trial like the RACER study. The RACER study has several strengths. First, a direct comparison between CESM and FFDM, both with targeted US being allowed, is possible. Until now, some studies have investigated the comparison between CESM versus FFDM plus targeted US. ${ }^{27}{ }^{28}$ However, in clinical practice, suspicious findings on CESM are further evaluated with US as well. Klang et al. recently showed that in BI-RADS 3 lesions detected on CESM, targeted US could be used to determine the necessity to perform tissue sampling. ${ }^{30}$

Although CESM is superior to FFDM plus US, the difference in diagnostic accuracy is expected to increase again when CESM/US is compared with FFDM/US. To the best of our knowledge, this has not yet been studied before in a prospective study design.

Second, the patients' mental state during the recall and diagnostic work-up is thoroughly assessed by validated questionnaires. Due to the higher diagnostic performance of CESM, especially in terms of reducing the number of false-positive findings, it is expected that in the intervention arm fewer additional exams will be performed, such as follow-up after 6 or 12 months, or breast MRI. 
These additional exams cause a delay in the assessment of final diagnosis and increase health care costs; plus we hypothesize that this will influence a patient's mental state during these months. Finally, the study design allows for a cost-effectiveness analysis, showing us the impact on health care costs of both strategies during this period. We hypothesize that using CESM as a work-up tool is more efficient and cost-effective than following current standard care. If proven to be cost-effective, an important hurdle is taken towards acquiring reimbursement by health insurance companies for CESM, which at present frustrates the further introduction of CESM worldwide.

Using CESM as a work-up tool also has some limitations. The most important disadvantages are the increased radiation dose and the administration of iodine-based contrast agents. Regarding the increase in radiation dose, several studies have shown that mean radiation dose of CESM per exposure is in the range of 2.5-2.8 mGy. ${ }^{1831-33}$ In comparison, the radiation dose of FFDM in these studies varied from 1.4-1.8 mGy. Jeukens et al. showed that the CESM radiation dose is approximately 80\% higher than that in FFDM: 2.8 mGy versus $1.6 \mathrm{mGy}$, respectively. ${ }^{18}$ Nevertheless, it is still within internationally accepted limits and does not substantially increase breast cancer incidence or mortality in women recalled from screening, who are at least 50 years. We believe that this increased dose is justified in the dedicated population as outlined. The chance of acquiring breast cancer due to this radiation exposure is expressed in the life-attributable risk (LAR) numbers. For example, for a single view CESM acquisition having a mean radiation dose of $2.8 \mathrm{mGy}$ per exposure, the LAR number for cancer incidence is 0.4 in 100,000 persons at the age of 60 years. ${ }^{34}$ The LAR number for cancer mortality at this age is even 2-3 times lower. Some even advocate that there is no effect of radiation under a dose of $100 \mathrm{mSv}$. Hence, one may conclude that CESM exposure poses only a small additional risk compared to the life time risk for breast cancer incidence and mortality of 12,000 and 3,000 cases per 100,000 women, respectively. Regarding the use of iodine-based contrast, Houben et al. had in clinical practice in a similar population a low incidence $(0.6 \%)$ of adverse hypersensitivity reactions. ${ }^{10}$ In contrast, they also showed that occult cancers are being detected in 3-4\% of the recalled women by using CESM. Consequently, the chance of finding occult (small) breast cancers is higher than the chance of having adverse reactions to contrast administrations (which are all documented in the RACER study), which in our opinion would justify the use of a CESM-based work-up of women recalled from screening. 
In short, we believe that the prospective multicenter randomized controlled RACER study will show that in recalled women a work-up based on CESM will be more accurate than usual care (based on conventional imaging such as FFDM). Higher specificity at similar sensitivity will reduce false positives and the volumes of additional diagnostic exams required to reach a final diagnosis, ultimately leading to a decrease in health care costs and patient experienced anxiety in this period.

\section{Trial status}

Participants are currently enrolled via protocol version number 6.1. (April 23 $3^{\text {th }}$ 2019). The first participants were randomized in April 2018. Enrollment is expected to be completed before January $1^{\text {st }}, 2021$. 


\section{References}

1. Timmers JM, van Doorne-Nagtegaal HJ, Zonderland HM, et al. The Breast Imaging Reporting and Data System (BI-RADS) in the Dutch breast cancer screening programme: its role as an assessment and stratification tool. Eur Radiol 2012;22(8):1717-23. doi: 10.1007/s00330-012-2409-2 [published Online First: 2012/03/15]

2. Rijksinsituut voor Volksgezondheid en Milieu (RIVM). Uitvoeringskader Bevolkingsonderzoek Borstkanker 2018

3. Lobbes MB, Lalji U, Houwers J, et al. Contrast-enhanced spectral mammography in patients referred from the breast cancer screening programme. Eur Radiol 2014;24(7):1668-76. doi: 10.1007/s00330-014-3154-5 [published Online First: 2014/04/04]

4. van der Steeg AF, Keyzer-Dekker CM, De Vries J, et al. Effect of abnormal screening mammogram on quality of life. Br J Surg 2011;98(4):537-42. doi: 10.1002/bjs.7371 [published Online First: 2011/06/10]

5. Lalji UC, Houben IP, Prevos R, et al. Contrast-enhanced spectral mammography in recalls from the Dutch breast cancer screening program: validation of results in a large multireader, multicase study. Eur Radiol 2016;26(12):4371-79. doi: 10.1007/s00330016-4336-0 [published Online First: 2016/04/22]

6. Klompenhouwer EG, Duijm LE, Voogd AC, et al. Re-attendance at biennial screening mammography following a repeated false positive recall. Breast Cancer Res Treat 2014;145(2):429-37. doi: 10.1007/s10549-014-2959-x [published Online First: 2014/04/22]

7. Patel BK, Gray RJ, Pockaj BA. Potential Cost Savings of Contrast-Enhanced Digital Mammography. AJR Am J Roentgenol 2017;208(6):W231-W37. doi: 10.2214/AJR.16.17239 [published Online First: 2017/04/06]

8. Mori M, Akashi-Tanaka S, Suzuki S, et al. Diagnostic accuracy of contrast-enhanced spectral mammography in comparison to conventional full-field digital mammography in a population of women with dense breasts. Breast Cancer 2017;24(1):104-10. doi: 10.1007/s12282-016-0681-8 [published Online First: 2016/03/05]

9. Cheung YC, Lin YC, Wan YL, et al. Diagnostic performance of dual-energy contrastenhanced subtracted mammography in dense breasts compared to mammography 
alone: interobserver blind-reading analysis. Eur Radiol 2014;24(10):2394-403. doi: 10.1007/s00330-014-3271-1 [published Online First: 2014/06/15]

10. Houben IPL, Van de Voorde P, Jeukens C, et al. Contrast-enhanced spectral mammography as work-up tool in patients recalled from breast cancer screening has low risks and might hold clinical benefits. Eur $J$ Radiol 2017;94:31-37. doi: 10.1016/j.ejrad.2017.07.004 [published Online First: 2017/09/25]

11. Foundation ER. EQ-5D-5L User Guide: Basic Information on how to use the EQ-5D-5L instrument 2015 [cited 2018 May 23rd]. Available from: https://euroqol.org.

12. Versteegh M.M. VKM, Evers S.M., de Wit G.A., Prenger R., Stolk E.A. Dutch Tariff for the Five-Level Version of EQ-5D. Value Health 2016(19):343-52.

13. van der Ploeg H.M. DPB, Spielberger C.D. Manual for the Self-Assessment Questionnaire: The Dutch version of Spielberger's State-Trait Anxiety Inventory. Lisse: Swets \& Zeitlinger; 1980.

14. Saldanha IJ, Dickersin K, Wang X, et al. Outcomes in Cochrane systematic reviews addressing four common eye conditions: an evaluation of completeness and comparability. PLoS One 2014;9(10):e109400. doi: 10.1371/journal.pone.0109400 [published Online First: 2014/10/21]

15. Dromain C, Balleyguier C, Muller S, et al. Evaluation of tumor angiogenesis of breast carcinoma using contrast-enhanced digital mammography. AJR Am J Roentgenol 2006;187(5):W528-37. doi: 10.2214/AJR.05.1944 [published Online First: 2006/10/24]

16. Lobbes MB, Smidt ML, Houwers J, et al. Contrast enhanced mammography: techniques, current results, and potential indications. Clin Radiol 2013;68(9):935-44. doi: 10.1016/j.crad.2013.04.009 [published Online First: 2013/06/25]

17. Houben IP, van Berlo CJ, Bekers O, et al. Assessing the Risk of Contrast-Induced Nephropathy Using a Finger Stick Analysis in Recalls from Breast Screening: The CINFIBS Explorative Study. Contrast Media Mol Imaging 2017;2017:5670384. doi: 10.1155/2017/5670384 [published Online First: 2017/11/04]

18. Jeukens CR, Lalji UC, Meijer E, et al. Radiation exposure of contrast-enhanced spectral mammography compared with full-field digital mammography. Invest Radiol 2014;49(10):659-65. doi: 10.1097/RLI.0000000000000068 [published Online First: 2014/05/30] 
19. Jochelson MS, Dershaw DD, Sung JS, et al. Bilateral contrast-enhanced dual-energy digital mammography: feasibility and comparison with conventional digital mammography and MR imaging in women with known breast carcinoma. Radiology 2013;266(3):74351. doi: 10.1148/radiol.12121084 [published Online First: 2012/12/12]

20. Dean A.G. SKM, Soe M.M. Open Source Epidemiologic Statistics for Public Health: OpenEpi; 2013 [cited 2019 May 23rd]. Available from: www.openepi.com.

21. Hanley JA, Hajian-Tilaki KO. Sampling variability of nonparametric estimates of the areas under receiver operating characteristic curves: an update. Acad Radiol 1997;4(1):4958. doi: 10.1016/s1076-6332(97)80161-4 [published Online First: 1997/01/01]

22. Zorginstituut Nederland. Guideline for economic evaluations in healthcare. 2016 [cited 2019 May 23rd]. Available from: https://www.zorginstituutnederland.nl.

23. Bouwmans C, Krol M, Brouwer W, et al. IMTA Productivity Cost Questionnaire (IPCQ). Value Health 2014;17(7):A550. doi: 10.1016/j.jval.2014.08.1791 [published Online First: 2014/11/01]

24. Kanters TA, Bouwmans CAM, van der Linden N, et al. Update of the Dutch manual for costing studies in health care. PLoS One 2017;12(11):e0187477. doi: 10.1371/journal.pone.0187477 [published Online First: 2017/11/10]

25. Efron B. TRJ. An Introduction to the Bootstrap. New York: Chapmann \& Hall 1993.

26. Tagliafico AS, Bignotti B, Rossi F, et al. Diagnostic performance of contrast-enhanced spectral mammography: Systematic review and meta-analysis. Breast 2016;28:13-9. doi: 10.1016/j.breast.2016.04.008 [published Online First: 2016/05/11]

27. Dromain C, Thibault F, Diekmann F, et al. Dual-energy contrast-enhanced digital mammography: initial clinical results of a multireader, multicase study. Breast Cancer Res 2012;14(3):R94. doi: 10.1186/bcr3210 [published Online First: 2012/06/16]

28. Luczynska E, Heinze-Paluchowska S, Hendrick E, et al. Comparison between breast MRI and contrast-enhanced spectral mammography. Med Sci Monit 2015;21:1358-67. doi: 10.12659/MSM.893018 [published Online First: 2015/05/13]

29. Zhu X, Huang JM, Zhang K, et al. Diagnostic Value of Contrast-Enhanced Spectral Mammography for Screening Breast Cancer: Systematic Review and Meta-analysis. Clin Breast Cancer 2018;18(5):e985-e95. doi: 10.1016/j.clbc.2018.06.003 [published Online First: 2018/07/10]

30. Klang E, Krosser A, Amitai MM, et al. Utility of routine use of breast ultrasound following contrast-enhanced spectral mammography. Clin Radiol 2018;73(10):908 e11-08 e16. doi: 10.1016/j.crad.2018.05.031 [published Online First: 2018/07/26] 
31. Badr S, Laurent N, Regis C, et al. Dual-energy contrast-enhanced digital mammography in routine clinical practice in 2013. Diagn Interv Imaging 2014;95(3):245-58. doi: 10.1016/j.diii.2013.10.002 [published Online First: 2013/11/19]

32. James JR, Pavlicek W, Hanson JA, et al. Breast Radiation Dose With CESM Compared With 2D FFDM and 3D Tomosynthesis Mammography. AJR Am J Roentgenol 2017;208(2):362-72. doi: 10.2214/AJR.16.16743 [published Online First: 2017/01/24]

33. Phillips J, Mihai G, Hassonjee SE, et al. Comparative Dose of Contrast-Enhanced Spectral Mammography (CESM), Digital Mammography, and Digital Breast Tomosynthesis. AJR Am J Roentgenol 2018;211(4):839-46. doi: 10.2214/AJR.17.19036 [published Online First: 2018/08/01]

34. National Research Council (N.R.C.) Health Risks from Exposure to Low Levels of Ionizing Radiation: BEIR VII Phase II Washington DC, USA: The National Academies; 2006 [2017]. 




\section{Chapter 7}

\section{Discussion}





\section{Discussion}

CEM is a rising breast imaging technique that is more and more embraced in the breast imaging community. This is reflected by the increased amount of scientific publications that can be observed. For example, until the introduction of a commercially available system in 2011 , only four publications were identified using the PubMed database and the search term 'contrastenhanced spectral mammography'. Subsequently, the number of publications steadily increased, reaching a total of 112 at the end of August 2020 (Figure 1), of which 7 included publications originated from the Netherlands. ${ }^{1}$

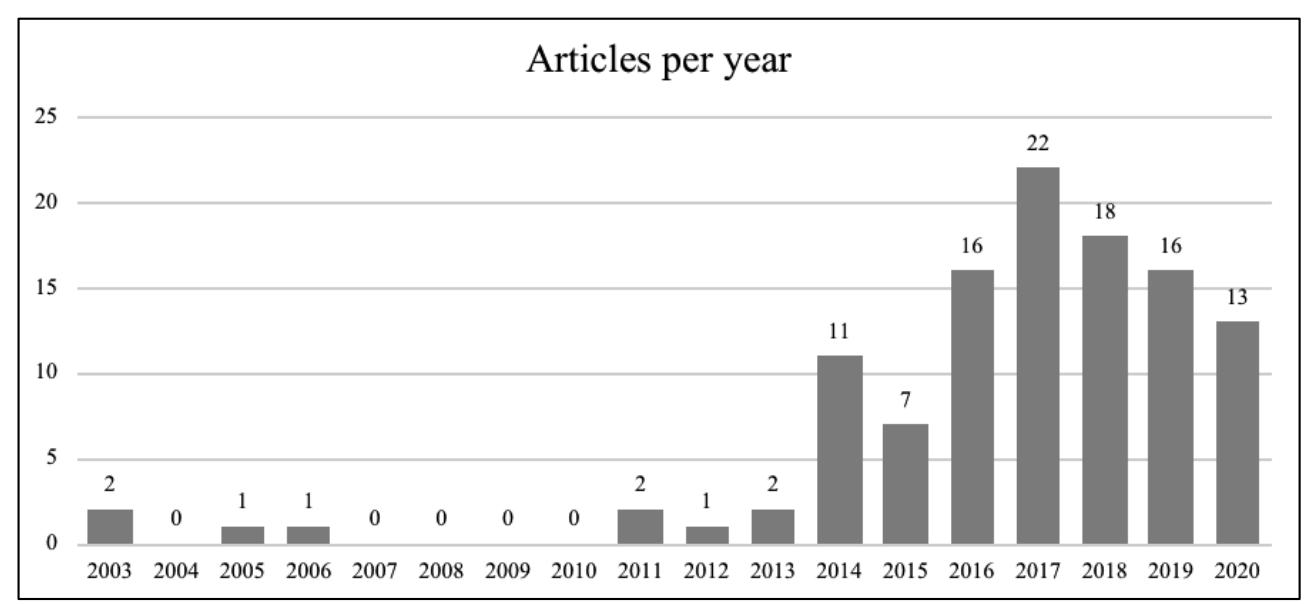

Figure 1. Graphic showing the number of articles published per year on contrast-enhanced mammography until August 2020. Adapted from Zanardo et al. ${ }^{1}$ and updated according to the study selection used by Zanardo.

Since the introduction of CEM, studies have consistently concluded that the performance of CEM is superior to FFDM and matches the diagnostic accuracy of breast MRI. ${ }^{2-5}$ The results of the studies have certainly contributed to more acceptance of CEM in the clinical setting. However, before a novel modality can be fully implemented, several hurdles need to be overcome. 


\section{Increased radiation dose}

By using two different exposures per breast per view, the radiation dose of CEM is default higher than that in FFDM. ${ }^{6}$ Nevertheless, this was not observed in one of the first publications on this topic by Fallenberg et al. who showed that there was a slight decrease in radiation dose when using CEM, which is contra intuitive. ${ }^{7}$ Different types of FFDM images (mixed digital and computed radiography images) from different vendors were compared with a prototype CEM device. ${ }^{7}$ Jeukens et al. studied the radiation dose of CEM and FFDM per exposure after first validating the output of radiation dose provided in the DICOM data. ${ }^{6}$ As these were within acceptable limits, the DICOM information of clinical FFDM and CEM images was used to determine the radiation dose used per image acquisition and for different breast thicknesses. They showed that the mean radiation dose of a single FFDM exposure was $1.6 \mathrm{mGy}$, while the mean radiation dose of a single CEM exposure was $2.8 \mathrm{mGy}$. Although this resulted in an $81 \%$ increase in radiation dose, the harmful effects on the patient are negligible. With these exposures, the lifetime attributable risk (LAR) numbers are very low for women aged 40 years $(0.009 \%)$, dropping to almost zero in women of 50 years and over, which is the population of interest in which CEM is used most often within our institute. ${ }^{8}$ These findings were later confirmed by Phillips et al. and showed that the harmful effects of CEM are limited even if this increased radiation dose is used. ${ }^{9}$ Nevertheless, radiologists should always apply the As Low As Reasonably Achievable (ALARA) principle, so the indication for CEM must justify the use of an increased amount of radiation.

\section{Evaluation of image quality}

Although the settings of the low energy images of CEM are comparable to FFDM, it is essential to confirm that no loss in image quality will occur when applying CEM. Initially, two studies investigated the comparability of FFDM and CEM image quality. A study by Fallenberg et al. focused on cancer detection and its size estimation of mammography and CEM and showed no inferiority against FFDM. ${ }^{7}$ Franscescone et al. had a similar study setup; however, more technical parameters, i.e. nipple line distance, compression thickness and compression force, were studied. All given parameters showed no statistically significant difference. ${ }^{11}$ 
After these results, Lalji et al. tested the image quality according to the strict requirements of the European Reference organisation for Quality Assured Breast Screening and Diagnostic Services (EUREF). For the majority of the twenty image quality criteria, no differences were observed. The delineation of the pectoral muscle was determined to be less accurate than in FFDM images. However, the authors concluded that this does not hold any clinical consequences, as breast MRI should be strongly considered when a mass is close to the chest wall, or the mediolateral oblique view could even be repeated in FFDM mode in a worst-case scenario. In contrast, the visibility of (micro) calcifications was superior in CEM, for which the authors suggested that this was presumably caused by post-processing of the images, as no alternative explanation could be observed. ${ }^{12} 13$

Nevertheless, this latter finding could be of clinical relevance. Since these calcifications are associated with DCIS, they can transform into invasive breast cancer. Therefore, we studied this potential benefit of CEM in a larger group of women, who were recalled from screening for suspicious calcifications. The initial results by Lalji et al. could not be repeated in this larger population. ${ }^{13}$ Similar sensitivity and specificity for FFDM and CEM in detecting suspicious calcifications were found. However, it is difficult to assess the extent of disease of DCIS, which can be concluded from the much higher rate of positive surgical resection margins. ${ }^{14}$ Regarding the extent of disease assessed by FFDM and CEM, Cheung et al. concluded with a better agreement between measurement performed on CEM compared to FFDM, albeit that was a relatively small difference $(4.2 \mathrm{~mm}$ vs $0.5 \mathrm{~mm}) .{ }^{15}$ In our study, we additionally investigated whether this would result in an alternative surgical treatment. We did not observe any benefit of performing CEM in suspicious breast calcifications regarding surgical decision making. ${ }^{16}$ Considering these results, we can conclude that the image quality of CEM is similar to FFDM, but there is no additional value of performing CEM for the evaluation, assessment of extent of disease or local staging of cases with suspicious breast calcifications. 


\section{Contrast administration}

In order to perform CEM, it is essential to administer a contrast agent. This comes along with theoretically introducing risks related to contrast administration, such as hypersensitivity reactions, although the volume of contrast administered is not related to the risk.

With the introduction of non-ionic iodinated contrast, the incidence of immediate hypersensitivity reactions has decreased. Nowadays, $0.7-3.1 \%$ of patients is estimated to develop mild adverse hypersensitivity reactions whereas $0.02-0.04 \%$ might develop severe adverse reactions when using these contrast agents. ${ }^{17}$ These numbers are in line with our current observations, with adverse reactions being observed in $0.6 \%$ of cases(chapter 4 ). Since hypersensitivity reactions are inevitable (despite their low occurrence), a radiology department should be well equipped with various treatment options to cope with these reactions. Based on our experiences, we recommend that staff should be periodically trained specifically for such emergency events.

Besides adverse reaction allergies to the contrast agent, contrast-induced nephropathy is another potential side-effect of administering iodine-based contrast agents, with a reported incidence from 1 to $30 \%{ }^{18}$

To assess the potential risk of developing PC-AKI, the renal function (i.e. serum creatinine levels) needs to be measured forefront. The odds ratio of developing PC-AKI increases at eGFR levels below $45 \mathrm{ml} / \mathrm{min} / 1.73 \mathrm{~m}^{2}{ }^{17}$ As PC-AKI cannot be treated casually, (inter-) national guidelines focus on its prevention, for example by using prehydration protocols for patients at risk of PC-AKI. Guidelines regarding the prevention of PC-AKI are a topic of continuous debate. Many guidelines recommend the assessment of renal function by a blood sample. In contrast, the application of CEM is usually determined at first contact with a client, and drawing a blood sample immediately before CEM will lead to delayed waiting times and logistical challenges on site. Although a rapid point-of-care (POC) test seems to be an attractive solution since whole blood sampling is logistically demanding, we concluded that the sensor for whole blood sample creatinine measurements used in our study was not accurate enough for this purpose: only a small group of seven patients were categorized as a high-risk patients based on the POC test used, with two developing(self-limiting)PC-AKI. However, six out of seven high-risk patients based on the classic creatinine assessment were not correctly identified as being high-risk patients by the POC method. 
Parallel to this thesis, a study by Nijssen et al. showed that prehydration prophylaxis in highrisk patients as defined by the guidelines (eGFR $<60 \mathrm{ml} / \mathrm{min} / 1.73 \mathrm{~m}^{2}$ ) was not superior to withholding prophylaxis before i.a. and i.v. contrast administration. ${ }^{19}$ In this randomized controlled trial, 660 consecutive patients at risk of developing PC-AKI (according to the guidelines) were randomized into two study arms: no prophylaxis versus standard prophylactic intravenous hydration. Subsequently, dialysis and mortality data were collected, showing that not giving prophylaxis to elective patients with eGFR levels $30-59 \mathrm{ml} / \mathrm{min} / 1.73 \mathrm{~m}^{2}$ is safe, even in the long-term. ${ }^{19}$ Based on these results, the Dutch guidelines lowered the threshold for the use of preventive prehydration to an eGFR level of $30 \mathrm{ml} / \mathrm{min} / 1.73 \mathrm{~m}^{2}$ just after completion of the CINFIBS study. This triggered us to review the internal data of our CINFIBS study, showing that only 3 out of 344 women had an eGFR level below $45 \mathrm{ml} / \mathrm{min} / 1.73 \mathrm{~m}^{2}$, with none below a level $<30 \mathrm{ml} / \mathrm{min} / 1.73 \mathrm{~m}^{2}$.

The new definition of "high risk" in terms of PC-AKI has relevant consequences for patient handling. First, a minority of patients is regarded as being at risk. These patients, who are still at risk, are normally aware of their kidney disease and the additional waiting times for an actual eGFR measurement and additional prophylaxis (if applicable) seems justified.

Consecutive to the AMACING study, Nijssen et al. showed in the CINART study that the new guidelines lead to a substantial reduction in hospital admissions as well as prophylaxisassociated complications resulting in a remarkable impact on daily clinical practice for patients and hospitals with substantial savings for the health care budgets. ${ }^{20}$

Hence, we concluded that the population of women attending our breast imaging unit has a very low a priori chance of being at risk of developing clinically relevant PC-AKI, especially if they do not report or are known with impaired renal function. Together with our hospital's contrast media safety committee, the Contrast-Induced Nephropathy Group (CIN-Group), we chose to inquire about any potential renal function impairment using a questionnaire before the CEM exam, in which also any known hypersensitivity reactions to iodine-based contrast agents is noted (Figure 2). ${ }^{21}$ However, internal hospital policies regarding the assessment of PC-AKI risk may still vary worldwide. 


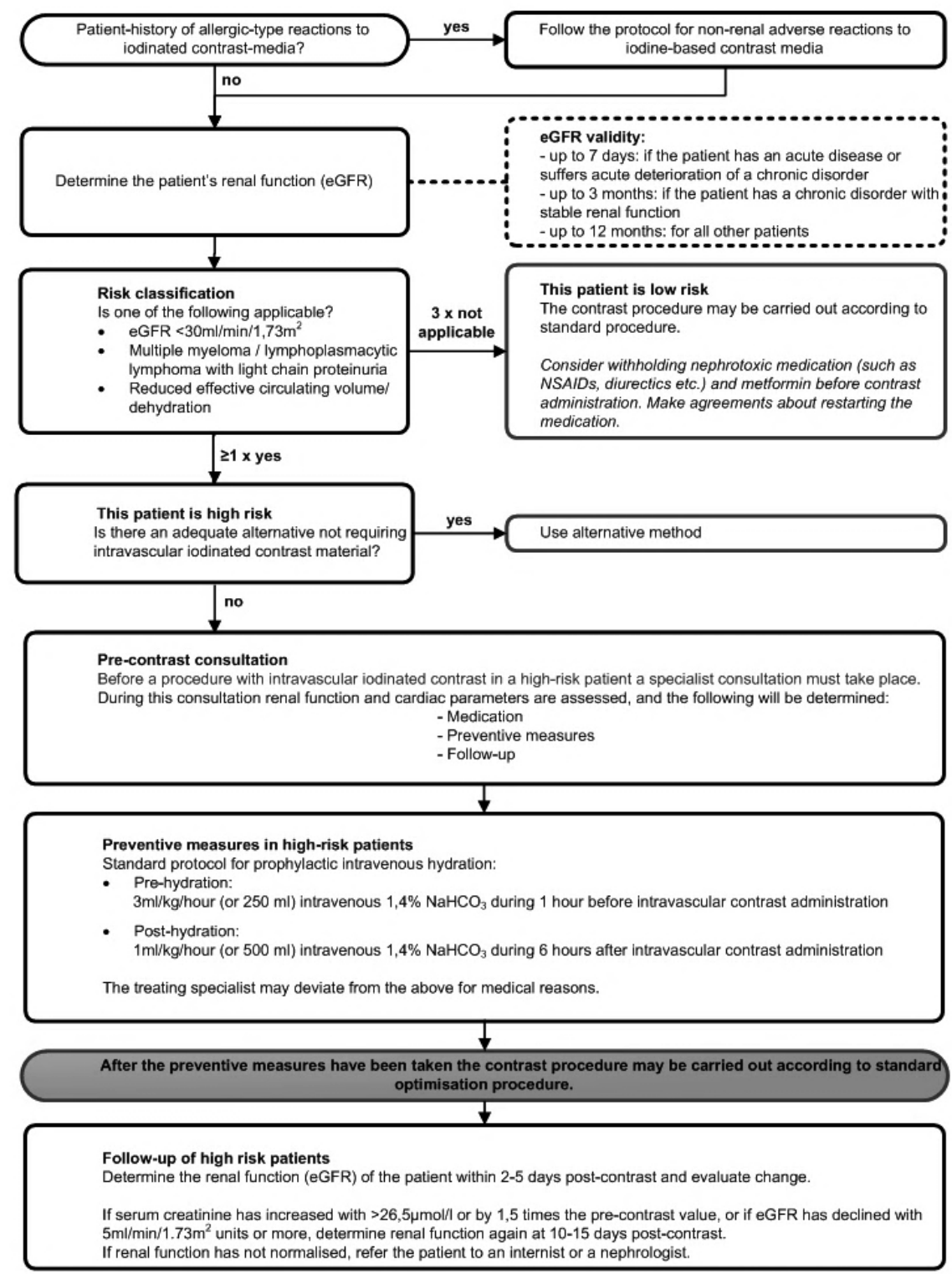

Figure 2. Risk screening and preventive measures for elective procedures with intravascular iodinated contrast administration flowchart. ${ }^{21}$ 


\section{CEM as screening modality}

Although the use of iodinated contrast agents and the increased radiation dose of CEM have been considered disadvantageous for CEM as a screening tool, recent studies have shown that CEM should at least be considered an alternative to breast MRI in women at high risk of developing breast cancer. The DENSE trial has demonstrated that women with dense breasts and a negative screening FFDM benefit from supplemental breast MRI. This, however, results in logistical and financial challenges as the use of a contrast agent might also hamper the implementation of breast MRI in this setting. Diagnostic accuracy of CEM is at least equal when compared to breast MRI, with women who have a slight preference for undergoing $\mathrm{CEM}^{22}$ In addition, it is cheaper, faster to read and easier to implement on a large scale. ${ }^{23}$ Based on recent studies, CEM is more and more considered as a screening tool as well. ${ }^{24}$ Consequently, in the near future, CEM might not only be considered to evaluate patients but also clients.

With respect to screening high-risk women (who are often screened starting at the age of 25), it must be emphasized that radiation dose will be an issue, especially for repeat CEM (bi-) annually. In an attempt to solve this problem, Lobbes et al. studied the diagnostic accuracy of a single view CEM (i.e., MLO only) versus a full CEM exam. ${ }^{10}$ Although the non-inferiority of this novel strategy could not be confirmed, the authors concluded that the number of potentially missed cancer was not acceptable. ${ }^{10}$ Thus, if CEM is to be considered a screening tool in these women, it must still consist of a complete, two-view examination. Technical developments should therefore focus on reducing the radiation dose used in these exams. 


\section{Learning CEM and its future outlook}

Since the introduction of CEM, studies have consistently concluded that the performance of CEM is superior to FFDM and equal to MRI. With its increased diagnostic performance, CEM is an excellent problem-solving tool for women recalled from the breast cancer screening programme. ${ }^{2}$ CEM-experienced radiologists were able to acquire an increase of sensitivity $(+3.1 \%)$ and specificity $(+45.7 \%)$ when compared to FFDM's images. Since these patients were only scored by CEM-experienced radiologists, it is difficult to estimate the performance of CEM in daily clinical practice since the experience levels of radiologists might vary. Hence, we studied the performance of CEM with ten readers having different levels of expertise in the use of CEM. This study confirmed earlier results and proved CEM to be beneficial to radiologists with different levels of experience. This study suggests that the learning curve of CEM is steep, especially for radiologists with some mammographic experience already. To some extent, this was also reflected by a recent study by Van Nijnatten et al. In the study, firstand second-year high school students were asked to assess CEM exams from cases of breast cancers that were previously missed by radiologists using FFDM. The students, obviously nonmedical students, acquired a sensitivity of $82.6 \%$ using CEM. ${ }^{25}$ These results showed that CEM is not only able to increase the diagnostic accuracy of FFDM but can also stress the necessity to add decision-supporting software for less experienced readers as well as open the window for automated (deep learning) solutions based on CEM algorithms.

An important limitation of most of the currently available studies is the retrospective study design. To achieve a higher rate of acceptance within the imaging and oncologic community, prospective studies are needed. In chapter 6 , we presented the outline of the prospective RACER study, in which we hypothesize that the diagnostic accuracy, cost effectiveness and patient comfort will be in favor of CEM (in the workup of women recalled from breast cancer screening). 
Within our study group, CEM research has mainly focused on the workup of women recalled from breast cancer screening. However, one could argue that there is a role for CEM in the screening of women, despite the increased radiation dose and the application of iodine-based contrast agents being an important disadvantage in this setting. Recently, a large 'ContrastEnhanced Mammography Imaging Screening Trial' (CMIST) was announced to open in 2020, comparing the screening performance of CEM in women at average-to-intermediate breast cancer risk and having dense breasts to the combination of digital breast tomosynthesis and whole breast ultrasound.

More interestingly, a Dutch study showed that supplemental breast MRI in women with dense breasts that were not recalled by screening using FFDM may benefit from this additional imaging. ${ }^{26}$ By using supplemental MR imaging, the authors found that the interval cancer rate dropped from 5.0 per 1,000 screenings in the FFDM group to 2.5 per 1,000 when adding breast MRI in these women. Although these results are very promising, the most important limitation of this project is the use of breast MRI. Based on current estimates, in the Netherlands, approximately 60,000 additional breast MRI exams need to be performed annually.

In summary, CEM might be a very practical alternative in this situation. 


\section{Computer-aided detection}

Despite further investigations on the clinical implementation of CEM, other developments are equally interesting. These developments focus on the ability to quantify the rate of enhancement observed in recombined CEM images.

Several studies describe certain pathognomonic signs, such as the 'eclipse' sign as distinctive for simple cysts. ${ }^{27}$ Van Nijnatten et al. showed that ILC has a lower enhancement compared to IDC. ${ }^{28}$ These findings suggest that the enhancement level contains information relevant for final lesion characterization. A proof-of-principle study by Lobbes et al. showed that enhancement quantification is feasible using a custom-made quantifier tool. In general, breast cancers show a more pronounced enhancement than benign lesions. In short, there seems to be important information 'hidden' with breast lesions seen on CEM, which cannot be captured by the naked eye. In these cases, the use of radiomics and deep-learning applications might further improve the extraction of diagnostic information from these images. ${ }^{29} 30$

Research groups within our university have already started developing promising software tools based on deep-learning algorithms, enabling computers not only to detect but also to contour and classify breast lesions (semi-) automatically. 


\section{Conclusion}

CEM is a novel breast imaging tool increasingly being used in clinical practice, as many studies have shown that its diagnostic accuracy is superior to FFDM and matches the accuracy of breast MRI, not only in detecting but also assessing the extent of disease. In prior studies, and in studies that are part of this thesis, hurdles that might have prevented more widespread clinical implementation were addressed. These included its disadvantages such as radiation dose use and contrast administration and its benefits such as its diagnostic accuracy and steep learning curve.

The time has come for CEM to further expand. With the increased diagnostic performance now known, prospective clinical studies are needed to define proper and definite CEM indications for women recalled from the breast cancer screening programme. In addition, current insights have shown that the application of machine learning is promising in CEM and warrants further research in the field. 


\section{References}

1. Zanardo M, Cozzi A, Trimboli RM, et al. Technique, protocols and adverse reactions for contrast-enhanced spectral mammography (CESM): a systematic review. Insights Imaging 2019;10(1):76. doi: 10.1186/s13244-019-0756-0 [published Online First: 2019/08/04]

2. Lalji UC, Houben IP, Prevos R, et al. Contrast-enhanced spectral mammography in recalls from the Dutch breast cancer screening program: validation of results in a large multireader, multicase study. Eur Radiol 2016;26(12):4371-79. doi: 10.1007/s00330016-4336-0 [published Online First: 2016/04/22]

3. Lobbes MB, Smidt ML, Houwers J, et al. Contrast enhanced mammography: techniques, current results, and potential indications. Clin Radiol 2013;68(9):935-44. doi: 10.1016/j.crad.2013.04.009 [published Online First: 2013/06/25]

4. Lalji U, Lobbes M. Contrast-enhanced dual-energy mammography: a promising new imaging tool in breast cancer detection. Womens Health (Lond) 2014;10(3):289-98. doi: 10.2217/whe.14.18 [published Online First: 2014/06/24]

5. Thibault F, Balleyguier C, Tardivon A, et al. Contrast enhanced spectral mammography: better than MRI? Eur J Radiol 2012;81 Suppl 1:S162-4. doi: 10.1016/S0720048X(12)70068-2 [published Online First: 2013/06/13]

6. Jeukens CR, Lalji UC, Meijer E, et al. Radiation exposure of contrast-enhanced spectral mammography compared with full-field digital mammography. Invest Radiol 2014;49(10):659-65. doi: 10.1097/RLI.0000000000000068 [published Online First: 2014/05/30]

7. Fallenberg EM, Dromain C, Diekmann F, et al. Contrast-enhanced spectral mammography: Does mammography provide additional clinical benefits or can some radiation exposure be avoided? Breast Cancer Res Treat 2014;146(2):371-81. doi: 10.1007/s10549-014-3023-6 [published Online First: 2014/07/06]

8. American association of physicists in medicine. AAPM position statement on radiation risks from medical imaging procedures 2011 [Policy number PP25-A]. 2017.

9. Phillips J, Mihai G, Hassonjee SE, et al. Comparative Dose of Contrast-Enhanced Spectral Mammography (CESM), Digital Mammography, and Digital Breast Tomosynthesis. AJR Am J Roentgenol 2018;211(4):839-46. doi: 10.2214/AJR.17.19036 [published Online First: 2018/08/01] 
10. Lobbes MBI, Hecker J, Houben IPL, et al. Evaluation of single-view contrast-enhanced mammography as novel reading strategy: a non-inferiority feasibility study. Eur Radiol 2019;29(11):6211-19. doi: 10.1007/s00330-019-06215-7 [published Online First: 2019/05/11]

11. Francescone MA, Jochelson MS, Dershaw DD, et al. Low energy mammogram obtained in contrast-enhanced digital mammography (CEDM) is comparable to routine full-field digital mammography (FFDM). Eur $J$ Radiol 2014;83(8):1350-5. doi: 10.1016/j.ejrad.2014.05.015 [published Online First: 2014/06/17]

12. European Reference Organisation for Quality Assured Breast Screening and Diagnostic Services (EUREF). European guidelines for Quality Assurance in breast cancer screening and diagnosis. 2013 [Available from: http://www.euref.org/europeanguidelines 2017.

13. Lalji UC, Jeukens CR, Houben I, et al. Evaluation of low-energy contrast-enhanced spectral mammography images by comparing them to full-field digital mammography using EUREF image quality criteria. Eur Radiol 2015;25(10):2813-20. doi: 10.1007/s00330015-3695-2 [published Online First: 2015/03/31]

14. van Esser S, Peters NH, van den Bosch MA, et al. Surgical outcome of patients with corebiopsy-proven nonpalpable breast carcinoma: a large cohort follow-up study. Ann Surg Oncol 2009;16(8):2252-8. doi: 10.1245/s10434-009-0513-6 [published Online First: 2009/05/14]

15. Cheung YC, Tsai HP, Lo YF, et al. Clinical utility of dual-energy contrast-enhanced spectral mammography for breast microcalcifications without associated mass: a preliminary analysis. Eur Radiol 2016;26(4):1082-9. doi: 10.1007/s00330-015-3904-z [published Online First: 2015/07/15]

16. Paajanen H, Kyhala L, Varjo R, et al. Effect of screening mammography on the surgery of breast cancer in Finland: a population-based analysis during the years 1985-2004. Am Surg 2006;72(2):167-71. [published Online First: 2006/03/16]

17. Davenport MS, Khalatbari S, Cohan RH, et al. Contrast material-induced nephrotoxicity and intravenous low-osmolality iodinated contrast material: risk stratification by using estimated glomerular filtration rate. Radiology 2013;268(3):719-28. doi: 10.1148/radiol.13122276 [published Online First: 2013/04/13]

18. Levey AS, Coresh J, Greene T, et al. Using standardized serum creatinine values in the modification of diet in renal disease study equation for estimating glomerular filtration 
rate. Ann Intern Med 2006;145(4):247-54. doi: 10.7326/0003-4819-145-4-20060815000004 [published Online First: 2006/08/16]

19. Nijssen EC, Nelemans PJ, Rennenberg RJ et al. Prophylactic intravenous hydration to protect renal function from intravascular iodinated contrast material (AMACING): a prospective, randomised, controlled trial. EClinicalMedicine. 2018;9;4-5:109-116. doi: 10.1016/j.eclinm.2018.10.007.

20. Nijssen, E.C., Nelemans, P.J., Rennenberg, R.J. et al. Impact on clinical practice of updated guidelines on iodinated contrast material: CINART. Eur Radiol 30, 4005-4013 (2020). https://doi.org/10.1007/s00330-020-06719-7

21. CIN-group, Maastricht Medical Centre (MUMC+), Prevention of contrast induced acute kidney injury (CI-AKI), Odin protocol, Version 10, 7 pages.

22. Hobbs MM, Taylor DB, Buzynski S, et al. Contrast-enhanced spectral mammography (CESM) and contrast enhanced MRI (CEMRI): Patient preferences and tolerance. J Med Imaging Radiat Oncol. 2015 Jun;59(3):300-5. doi: 10.1111/1754-9485.12296.

23. Patel BK, Gray RJ, Pockaj BA. Potential Cost Savings of Contrast-Enhanced Digital Mammography. AJR Am J Roentgenol. 2017 Jun;208(6):W231-W237. doi: 10.2214/AJR.16.17239.

24. Sung, J. S., Lebron, L., Keating, D., et al. (2019). Performance of Dual-Energy Contrastenhanced Digital Mammography for Screening Women at Increased Risk of Breast Cancer. Radiology, 293(1), 81-88. doi:10.1148/radiol.2019182660

25. van Nijnatten TJA, Smidt ML, Goorts B, et al. Can high school students help to improve breast radiologists in detecting missed breast cancer lesions on full-field digital mammography? J Cancer 2019;10(3):765-71. doi: 10.7150/jca.30494

26. Bakker, MF, de Lange, SV, Pijnappel, RM, et al. 2019). Supplemental MRI Screening for Women with Extremely Dense Breast Tissue. N Engl J Med, 381(22), 2091-2102. doi:10.1056/NEJMoa1903986

27. Lobbes MB, Lalji U, Houwers J, et al. Contrast-enhanced spectral mammography in patients referred from the breast cancer screening programme. Eur Radiol 2014;24(7):1668-76. doi: 10.1007/s00330-014-3154-5

28. Nijnatten TJ, Jochelson MS, Pinker K, et al. Differences in degree of lesion enhancement on CEM between ILC and IDC. BJR 2019;1(1):20180046. doi: $10.1259 /$ bjro.20180046 
29. Lobbes MBI, Mulder HKP, Rousch M, et al. Quantification of enhancement in contrastenhanced spectral mammography using a custom-made quantifier tool (I-STRIP): A proof-of-concept study. Eur $J$ Radiol 2018;106:114-21. doi: 10.1016/j.ejrad.2018.07.021 [published Online First: 2018/08/29]

30. van Wijk Y., Woodruff. H. et al. (2018). Radiomics on contrast enhanced spectral mammography for improved Breast cancer diagnosis. Paper presented at the European Society of Radiology Annual congress. 



\section{Impactparagraaf}




\section{Impactparagraaf}

Een op de zeven Nederlandse vrouwen wordt getroffen door borstkanker. Om in een vroeg stadium borstkanker te detecteren, worden vrouwen tussen de 50 en 75 jaar elke twee jaar uitgenodigd om deel te nemen aan het landelijke bevolkingsonderzoek. Indien er bij deze screening een verdachte borstafwijking wordt waargenomen, wordt de vrouw doorverwezen naar een keuze ziekenhuis voor verdere diagnostiek.

'Contrast-enhanced mammography' (CEM) is een onderzoeksmethode die geschikt is voor de verdere evaluatie van vrouwen verwezen door het bevolkingsonderzoek. Eerder onderzoek toonde aan dat CEM met een grotere nauwkeurigheid dan reguliere mammografie kan vaststellen of de verwezen afwijking berust op borstkanker of op 'vals alarm', zoals bijvoorbeeld overprojectie van klierweefsel, een cyste of een andere goedaardige afwijking. Met name het aantal controle onderzoeken na bijvoorbeeld zes en twaalf maanden neemt sterk af bij CEM. Indien CEM geen afwijkingen toont, is het verantwoord om de vrouw pas na twee jaar, dit wil zeggen in de volgende screeningsronde, opnieuw te beoordelen.

Ondanks de grotere diagnostische nauwkeurigheid van deze techniek, moeten er verschillende hordes genomen worden alvorens men de techniek kan implementeren in de alledaagse praktijk van een ziekenhuis.

Eerdere studies van onze groep toonden reeds aan dat de beeldkwaliteit van CEM, met name de zogenaamde 'low-energy' beelden, kwalitatief niet onder doen voor een regulier mammogram. Daarnaast werd bevestigd dat de beelden door borstradiologen nauwkeurig beoordeeld konden worden en dat vrijwel alle verwezen vrouwen in theorie in aanmerking zouden kunnen komen voor dit onderzoek. Tot slot werd geconcludeerd dat de gebruikte hoeveelheid röntgenstraling (die iets hoger is bij CEM dan bij reguliere mammografie) niet de bovengrenzen van het toelaatbare overschreed. In dit proefschrift werd verder gekeken naar de stappen die genomen moeten worden om acceptatie in de praktijk te verwezenlijken.

In een van de studies in dit proefschrift werd nogmaals bevestigd dat patiënten die CEM ondergingen een sensitievere en specifiekere uitslag kregen (vergeleken met reguliere mammografie). Eenvoudiger uitgelegd: er werden iets meer borsttumoren ontdekt, maar ook was er minder vaak sprake van 'vals alarm'. Dit werd afgewogen tegen de nadelen van CEM, te weten de verhoogde stralingsdosis van de methode en het gebruik van contrastmiddelen (die mogelijk een tijdelijke achteruitgang van de nierfunctie kunnen veroorzaken of een overgevoeligheidsreactie). 
Hierbij concludeerden wij dat de voordelen van CEM veel zwaarder wegen, dan de nadelen. We toonden bovendien aan dat (expert) radiologen alsook radiologen in opleiding met weinig ervaring in het beoordelen van CEM een snelle leercurve vertoonden m.b.t. het beoordelen van de beelden.

Een belangrijke uitdaging bij de beoordeling van mammogrammen ligt in de beoordeling van zogenaamde (micro)verkalkingen. Deze kunnen een uiting zijn van een voorloperstadium van borstkanker. Deze verkalkingen zijn met name goed te zien op reguliere mammografie, maar wij hebben ook getoetst op CEM specifiek voor deze afwijkingen een meerwaarde zou hebben. Er bleek echter geen bijkomend voordeel van CEM in de beoordeling van microverkalkingen: niet in de mogelijkheid om ze te detecteren, maar ook niet als hulpmiddel voor chirurgische behandeling (de uitgebreidheid kon niet meer nauwkeurig bepaald worden met CEM).

Omwille van het gebruik van contrastvloeistof tijdens een CEM zal men rekening moeten houden met de nierfunctie. Patiënten met een verlaagde nierfunctie lopen namelijk het risico op een verslechtering van de nierfunctie door de contrastvloeistof. Om de nierfunctie in kaart te brengen wordt er ruim op voorhand van het onderzoek een bloedprik afgenomen en geanalyseerd in het laboratorium. Het vervangen van deze analyse op basis van een simpele vingerprik is erg aantrekkelijk aangezien het tijds efficiënt en minimaal invasief is. Derhalve werd gedurende de CINFIBS studie gebruik gemaakt van een vingerprik analyse. Hieruit bleek dat de POC testen niet gevoelig genoeg waren om de juiste risicopatiënten te detecteren. Derhalve werd besloten om terug te vallen op de laboratorium analyses om zodoende een reële kijk te hebben op een patiënt zijn nierfunctie en haar kans op verslechtering van de nierfunctie.

Concluderend kunnen we aan de hand van dit proefschrift stellen dat CEM een veelbelovende techniek is voor het opvolgen van patiënten die verwezen worden vanuit het bevolkingsonderzoek. De techniek is goed te implementeren in de dagelijkse praktijk, makkelijk aan te leren en de nadelen die het met zich meebrengt wegen niet op tegen de vele voordelen. 
Voor de toekomst liggen nog meer geavanceerde toepassingen in het verschiet. Kunstmatige intelligentie is opkomend in de medische beeldvorming. Hoewel er reeds computerprogramma's beschikbaar zijn voor de beoordeling van mammogrammen, lijkt vooral CEM zich te lenen voor toepassingen van kunstmatige intelligentie. In de toekomst zal het leiden tot een uitstekende ondersteunende functie voor de beoordelende radioloog en zullen de valkuilen van zowel de radioloog als de ondersteunende software elkaar complementeren om zodoende de meest optimale beoordeling te verkrijgen.

Op dit moment wordt binnen onze groep CEM verder geïmplementeerd in de kliniek. Een prospectieve, gerandomiseerde trial zal uitgevoerd worden tussen vrouwen die opgevolgd worden met reguliere beeldvorming (o.a. reguliere mammografie) versus opvolging met voornamelijk CEM. Door deze methode snel aan te kunnen bieden aan verwezen vrouwen, hopen wij sneller duidelijkheid te geven over het feit dat een afwijking verdacht is of berust op het eerder genoemde 'vals alarm'. Bij positieve resultaten zullen wij deze aanpak verder actief trachten te implementeren binnen Nederland, zodat alle verwezen vrouwen hiervan kunnen profiteren. 


Summary 



\section{Summary}

Breast cancer is one of the most common cancers in women. In the Netherlands, 1 out of 7 women (28\%) will be diagnosed with breast cancer in their lifetime.

Many countries provide women with some kind of regulated breast cancer screening programme. In the Netherlands, women between 50 and 75 years are invited for biannual mammography. If an abnormality is detected on these mammograms, the women are recalled to a hospital of their choice for further workup. Previous studies have shown that CEM could be a powerful problem-solving tool in these recalled women. The current thesis focuses on further clinical implementation of CEM, mainly adding on its ability to clarify screen-related abnormalities.

In chapter 2, a study on the possibility to speed up the whole exam procedure was set up. An adverse effect of contrast administration is contrast-induced nephropathy. To prevent the development of CIN, the POC device was used. The given eGFR in combination with a questionnaire made the radiologist to proceed with or refuse the CEM exam. Although a POC measurement is considerably faster than laboratory testing, the device seemed not to be reliable in assessing the renal functionality and therefore not able to prevent CIN. In parallel to this thesis, Nijssen et al. showed that the threshold for using prophylaxis to prevent PC-AKI can be safely lowered. With this, and reviewing our raw data acquired in the CINFIBS study, we concluded that the risk of developing PC-AKI in women recalled from the breast cancer screening programme with no known renal impairments is negligible.

The superiority of CEM to FFDM was already demonstrated in a group of 113 patients assessed by 3 readers experienced in CEM. To evaluate CEM clinical feasibility and the widespread application of CEM, we studied a much larger group in chapter 3, while the exams were read by ten readers with a different level of expertise. This study showed that the earlier results could be confirmed in these novel cases and even in radiologists with different levels of experience in CEM. This suggests that the learning curve of CEM is short, especially for radiologists with some mammographic experience already. 
Although the diagnostic accuracy of CEM is superior to FFDM, it is not flawless. In chapter 4, we found that women recalled from screening and imaged with CEM showed additional ('CEM-only') findings in $7.7 \%$ of a group of 839 women. The majority of these additional findings were malignant. The disadvantages of CEM consisted of the increased radiation dose and administration of contrast. We concluded that an increased radiation dose and administration of contrast did not outweigh the advantages of additional (malignant) findings. In chapter 5, the performance of CEM regarding suspicious calcifications and its disease extent were studied, as these are often associated with premalignant lesions (DCIS). These subtle precursors of invasive malignancies are often overlooked. In this chapter, the diagnostic accuracy of FFDM and CEM for calcifications was studied, specifically including assessment of the extent of disease and its (hypothetical) impact in surgery treatment. We showed that the diagnostic accuracy of CEM in suspicious calcifications is comparable to FFDM. Although CEM was more accurate in estimating the extent of disease, it did not result in any consequences in improved surgical outcome.

In chapter 6, when CEM would be feasible in clinical practice despite the risks, in the upcoming years, it will be important to improve the efficiency of breast cancer screening in women. This multicenter, prospective study will randomize the recalled women into two groups in which one group receives the standard care (conventional breast imaging) and the other group will receive CEM. The women will be assessed using questionnaires in order to monitor their state of mind during the process of the examination.

The results and conclusions of the mentioned studies above were summarized in chapter 7 . Results of prior studies, current findings of the studies presented in this thesis, and a future outlook were also discussed. 




\section{Samenvatting}





\section{Samenvatting}

Borstkanker is een van de meest voorkomende kankers bij vrouwen. In Nederland krijgt 1 op de 7 vrouwen (28\%) te maken met borstkanker. De incidentie is sinds 1990 verdubbeld en zal in de komende jaren verder toenemen. Een van de redenen waarom er een grote toename is van borstkanker is te wijten aan een beter screeningsprogramma. De effectiviteit van borstkankerdetectie wordt veroorzaakt door het ontwikkelen van nieuwe technieken. Een betere ontwikkeling of introductie van een techniek leidt tot een eerdere detectie en een betere nauwkeurigheid.

Hoofdstuk 2 bespreekt een studie waarbij men kijkt naar de mogelijkheid om de gehele CEMprocedure te versnellen. Een van de nadelige effecten van CEM blijft het toedienen van contrast. Hierbij kan een contrast-geïnduceerde nefropathie (CIN) optreden. Om de ontwikkeling op CIN te voorkomen wordt de nierfunctie via bloedafname getest en het risicoprofiel van de patiënt in kaart gebracht. Aangezien men vanaf de bloedafname ongeveer een uur moet wachten alvorens het serum creatinine bekend is, werd er gekeken naar een plaatsvervangend middel. Hierbij zou men het serum creatinine op basis van een point of care (POC) meting uitvoeren middels een vingerprik. CIN is vaak reversibel en zelf limiterend met betrekking tot blijvende nierschade. Het treedt op nadat de patiënt het contrastmiddel is toegediend. Het piekt 3 tot 5 dagen na de toediening en vaak na 30 dagen weer verdwenen. De glomerulaire filtratiesnelheid (eGFR)werd berekend in enkele seconden en in combinatie met de vragenlijst werd door de handelend radioloog beslist het onderzoek te vervolgen of te weigeren. Uit onze studie kunnen we concluderen dat een POC-meting aanzienlijk sneller is dan een bepaling via het lab, echter zijn de waarden van het POC-apparaat niet betrouwbaar bij het beoordelen van een patiënt haar risicoprofiel op het ontwikkelen van CIN.

In eerdere studies werd duidelijk dat CEM superieur is ten opzichte van FFDM. Om de klinische haalbaarheid en prestaties van CEM nog beter te evalueren, werd een grotere groep geïncludeerd in hoofdstuk 3. De groep bestond uit 199 patiënten. De groep van radiologen en assistenten in opleiding tot radiologen bestond uit vier ervaren CEM-lezers, drie niet-ervaren CEM-lezers en drie beoordelaars met beperkte training in mammografie en CEM. De fout positieven en fout negatieven van een of meer lezers werden opnieuw beoordeeld. Hierin bleek dat de fout positieven het gevolg waren van enige 'enhancement' van de laesie, de meerderheid 
van deze laesies betrof een fibroadenoom. De fout negatieven waren te wijten aan een suboptimale locatie afgebeeld in de rand van het onderzoek (twee gevallen) of 'nonenhancement' (mucineus carcinoom, een geval). De 'enhancement' van goedaardige laesies kan resulteren in een valkuil voor CEM-gebruikers. Dit kan resulteren in onnodige biopten. Alhoewel sommige fout-positieven en -negatieven optreden bij het gebruiken van CEM, blijkt de techniek wederom beter te zijn dan digitale mammografie. De toename in sensitiviteit en specificiteit laten een minder steile leercurve zien bij onervaren CEM-gebruikers en gebruiker met minimale training in de mammaradiologie zoals de assistenten in opleiding tot radioloog.

In Hoofdstuk 4 zijn alle vrouwen die zijn verwezen van de nationale screening op borstkanker tussen december 2012 en december 2015 geïncludeerd. De CEM onderzoeken werden beoordeeld door een expert. Er werden meerdere nevenbevindingen gedaan. Namelijk in 7,7\% van de extra bevindingen in een groep van 839 vrouwen vertoonden een meerderheid van kwaadaardige laesies. Rekening werd gehouden met de nadelen die een CEM onderzoek met zich meebrengt en dit werd in kaart gebracht. Zo bestonden de nadelen die een patiënt kan ondervinden uit de verhoogde stralingsdosis, contrast toediening en onnodige biopten op basis van een fout positief onderzoek. Ondanks de toename van de gegeven stralingsdosis kan men concluderen dat de hoeveelheid nog steeds te verwaarlozen was en binnen de gestelde richtlijnen valt. Het toedienen van contrast kan leiden tot ongewenste effecten zoals CIN of allergische reacties. Echter het opreden van zulke bijwerkingen is minimaal. Onnodige biopten gebaseerd op fout positieve bevindingen tijdens het CEM-onderzoek kunnen, gezien hun invasieve aard, leiden tot enige complicaties. Echter het optreden van complicaties zoals een bloeding of ontsteking is nagenoeg nihil. We concludeerden dat ondanks de benoemde nadelen van CEM, deze niet opwegen tegen de voordelen van het aantal toegenomen (kwaadaardige) nevenbevindingen.

In hoofdstuk 5 werden de prestaties van CEM met betrekking tot verdachte fijne calcificaties en de uitbreiding van ziekte. Deze subtiele voorlopers van invasieve maligniteiten worden vaak gemist. Het missen van verdachte micro calcificaties kan resulteren in een occulte manifestatie van borstkanker gedurende de tijd tussen de 2 screenings. Om de gevonden laesie chirurgisch te verwijderen, is de grootte van het gebied van het betrokken weefsel belangrijk, een onderschatting van het aangedane gebied kan resulteren in een incomplete verwijdering van de laesie. Dit kan leiden tot nieuwe operatie, die vaak ingrijpender verloopt of een verandering 
van therapie. Om het aangedane gebied dat door de CEM-gebruiker werd beoordeeld en de impact ervan op chirurgische behandelingen te beoordelen, werd een multidisciplinaire vergadering gesimuleerd met twee ervaren oncologische borstchirurgen. Samenvattend zijn de prestaties van CEM met betrekking tot de verdachte fijne calcificaties vergelijkbaar met FFDM, alhoewel CEM nauwkeuriger is in het schatten van de ziekte uitbreiding. Echter zal dit geen gevolgen hebben in de chirurgische uitkomst. Aangezien het verschil in schatting tussen FFDM en CEM kleiner is dan de gehanteerde chirurgische marge van $4 \mathrm{~mm}$ om de kans op volledige verwijdering te vergroten.

Om te bewijzen dat CEM, ondanks de verbonden risico's, haalbaar is in de klinische praktijk, zal de komende jaren zijn efficiëntie bij het screenend naar borstkanker verbeterd moeten worden. Dit wordt besproken in hoofdstuk 6. Deze prospectieve, multicentrische studie zal de doorverwezen vrouwen vanuit de nationale screening in twee groepen splitsen, waarbij één groep de standaardzorg (conventionele borstbeeldvorming) ontvangt en de andere groep CEM krijgt. De ervaringen van de vrouwen zullen worden beoordeeld met behulp van vragenlijsten

De resultaten en conclusies van genoemde onderzoeken worden besproken in hoofdstuk 7. Aan het einde van de discussie zal de mogelijke visie tot implementatie van CEM in de dagelijkse klinische praktijk op basis de besproken hoofdstukken worden gegeven. 



\section{Dankwoord}





\section{Dankwoord}

Alvorens mijn opleiding tot radioloog in het Zuyderland MC, heb ik naast mijn promotie onderzoek, coschappen gelopen als geneeskundestudent op de afdeling radiologie in het MUMC+. Ik wil zowel mijn toenmalige als huidige collega's in beide centra hartelijk bedanken welke een bijdrage hebben geleverd aan de totstandkoming van dit proefschrift, maar een aantal mensen in het bijzonder.

Met dank aan mijn copromotors dr. Lobbes en dr. Lalji. Beste Marc en Ulrich, wat begon als een introductie, heeft in de daaropvolgende jaren geleid tot het kweken van affiniteit voor het wetenschappelijk onderzoek. Gedurende mijn promotietraject heb ik mogen genieten van een goed mentorschap, waarbij ik jullie laagdrempelig kon benaderen, wat heeft geleid tot een mooi proefschrift.

Marc, jouw hulp was niet alleen cruciaal, zonder jouw gedrevenheid en energie was dit project onmogelijk geweest. Door jouw kritische blik werden mijn papers voorzien van zeer bruikbaar commentaar, wat de kwaliteit ten goede kwam. Je betrokkenheid heeft mij steeds opnieuw geprikkeld gemotiveerd te blijven richting de eindstreep van het schrijven van dit schrift. Dank hiervoor.

Beste Prof. dr. Wildberger, beste Joachim, ik wil je enorm bedanken voor de kans die je mij hebt geboden om te kunnen promoveren. Bedankt voor de vrijheid die je mij heeft gegeven om dit proefschrift te schrijven naast mijn geneeskunde studie en fulltime job als radioloog in opleiding. Ik bewonder jouw inzichten en kennis waar je mee klaar stond om mij te sturen tijdens het schrijven van mijn proefschrift. Een internationaal gerenommeerd duizendpoot met een volle agenda, waar altijd de deur open staat. Je bewaarde de rust en maakte tijd vrij om me te voorzien van advies of het geven van een luisterend oor. Tussen de serieuze gesprekken, leerde ik je ook persoonlijk kennen. Zo kwamen we er laatst achter dat wij al jaren maandelijks onze vrije tijd vertoeven aan het Ouddorpse strand. Ik hoop in de nabije toekomst elkaar nog eens daar tegen te komen. 
Koos en Thomas, de keuze om jullie als paranimfen te vragen was snel gemaakt.

Koos, respect voor hoe je alle ballen in de lucht weet te houden; als kersverse papa van de tweede, het net hebben afgerond van je eigen promotie en het draaien van diensten als radioloog in opleiding. Ik kan altijd bij je terecht voor vragen en je vindt altijd om met mij te sparren over het proefschrift, de opleiding of het vaderschap.

Thomas, of zoals Bob zegt, Bomas, ik heb je leren kennen wanneer ik begon met de opleiding en het klikte van dag 1 , bedankt voor de vele gezellige momenten tijdens en naast het werk. We zijn naast, collega's en vrienden, ook dorpsgenoten geworden en hebben al op veel gezellige avonden mogen proosten.

Prof. Dr. Liesbeth Boersma, Prof. Dr. René van der Hulst, Prof. Dr. Ruud Pijnappel, Prof. Dr. Koen Van de Vijver en Dr. Sanne Engelen hartelijk dank voor jullie tijd en moeite die jullie in het beoordelen van mijn proefschrift hebben gestoken.

Sigrid, Suzanne en Janneke waar ik eerst aan jullie geïntroduceerd werd als een bachelor geneeskunde student met interesse in onderzoek passeerde ik afgelopen jaren de revue als onderzoeksstudent, coassistent en nu als arts -assistent die onder jullie supervisie ervaring kon opdoen binnen de mammaradiologie. Het is enigszins onwerkelijk om, nu als differentiant mammaradiologie naast diegene te werken, waar ik zo naar opkeek de voorbije jaren.

Laboranten MUMC+ en het Zuyderland MC, in het bijzonder de 'Dames van de mammo' in het MUMC+, ik wil jullie allemaal bedanken voor jullie enthousiasme en inzet, iedere dag opnieuw, rondom de zorg van het maken van een contrast mammografie. Hartelijk dank voor de inspanning die jullie moesten leveren om zo data te kunnen verzamelen. Naast de patiëntenzorg en de serieuze zaken is er ook heel wat afgelachen. Waardoor het nu als arts assistent tijdens mijn mamma-stage voelt als thuiskomen.

Alle assistenten in zowel het Zuyderland MC als het MUMC+. Beide assistentengroepen voelen als een warm team en ik ben dan ook trots dat ik hier deel vanuit mag maken. In het bijzonder wil ik Paulien en Thiemo bedanken. Paulien hartelijk dank voor je werk tijdens onze onderzoekstage, wat eerst leek op wat datawerk resulteerde in een mooi artikel (hoofdstuk 4). Thiemo, naast radioloog i.o. ben je een getalenteerd onderzoeker en ik heb dan ook heel veel respect voor alles wat je aan onderzoek doet. 
Dit leidt dan ook tot meerdere onderzoeksprijzen, waaronder, een uiterst chique overnachting in Parijs met uitzicht op de beeldengalerij van het Louvre tijdens EUSOBI.

Mijn opleiders, Wendy, Roy en Linda voor jullie steun tijdens mijn opleiding. Ik kon bij jullie terecht om mijn hart te luchten en om advies vragen. Verplichte afspraken tijdens werkuren of een vrije dag nemen om bepaalde deadlines te halen waren nooit een probleem.

Lidewij voor al je inspanning binnen de RACER studie. Je was essentieel voor hoofdstuk 6 . Net de inclusie van de RACER studie gecompleteerd. Ik wens je heel veel succes in het vervolledigen van je studie alsook het proefschrift.

Beste Patty Nelemans en Cecile Jeukens, de eerste bevlogen in de statistiek en de andere in de klinische fysica, beide gebieden waar ik alvorens mijn onderzoek weinig van begreep maar alsnog gaandeweg tijdens mijn onderzoek in een begrijpbare taal uitleg heb gekregen. Cecile, het onderzoek met betrekking tot stralingsbelasting (hoofdstuk 4) is me goed bijgebleven, het gaf me veel inzicht in het onderzoek, maar ook de verschillende werkzaamheden als klinisch fysicus. Bovenal was het erg leuk om het onderzoek met jou op te zetten en te verrichten.

Esther en Marjolein, hartelijk dank voor al jullie inzet, chirurgische blik en gezelligheid tijdens het verkrijgen van data. Daarnaast heerlijk pragmatisch, waarin ik me als persoon zeer kan vinden.

Caroline Frotscher, altijd goedlachs en enthousiast, zeker wanneer het over de mammaradiologie gaat. Erg begaan met de patiënten en een omgangsvorm die ik bewonder. Bedankt voor je adviezen (vaak aan de voordeur). Iemand waar ik naar opkijk zowel als (mamma)radioloog als mens.

Alle mede-auteurs wil ik bedanken voor hun bijdrage, in het bijzonder Otto Bekers, Estelle Nijssen en Loes Kooreman voor hun enthousiasme, ondersteuning en uitleg over hun desbetreffende aandachtsgebied.

Het secretariaat medische beeldvorming, met name Monique Gerards, bedankt voor al je moeite, het inplannen van alle afspraken die ik in de voorbije jaren heb gemaakt alsook de voor correspondentie en het regelwerk rondom mijn promotie. 
Lieve pap, mam en Vera, jullie staan altijd voor me klaar. Een geweldige jeugd en de kansen en vrijheden die jullie mij hebben gegeven zorgen er dan ook voor dat ik hier nu sta en ik ongestoord verder kan doorbouwen aan mijn toekomst als radioloog. Afgelopen jaren kenden ups en downs met betrekking tot pap zijn gezondheid, echter we zijn er sterker en nog hechter uitgekomen als familie dan ooit tevoren.

Jan en Coby, dankjulliewel voor alles. Na de uitleg wat een promotietraject inhield kwam er als reactie: 'poeh poeh, dat is nogal wat dan.' Die nuchtere blik zorgde dat ik veel kon relativeren, de heerlijke avondjes buiten aan het open vuur met een whisky of biertje in de hand gaven veel rust (ongetwijfeld ook de Ouddorpse lucht).

Lieve Nicole, mijn rots in de branding. Afgelopen jaren waren hectisch met betrekking tot het promotietraject, een volledige huis verbouwing, de opleiding en de wisselende diensturen aan beide kanten, maar kon ik altijd genieten van je onvoorwaardelijke steun. Vaak stonden de opleiding en het promoveren op de voorgrond en moesten vele uitjes maar wachten. $\mathrm{Nu}$ meerdere zaken afgerond zijn kunnen we steeds meer genieten van elkaar en onze twee jongens! Ik bewonder je in alles wat je doet en zal er altijd voor je zijn, ik hou van je.

Last but not least, mijn twee mannen, Bob en Ted. Lieve Bob, ondanks dat je pas 2 jaar bent is het al bewonderenswaardig wat voor een mooi karaktertje in je huist. Een zorgzaam mannetje met energie voor drie. De liefste grote broer die papa, mama en Ted kunnen wensen. Blijf lekker zoals je bent. 




\section{Curriculum Vitae}





\section{Curriculum Vitae}

Ivo Houben, born the 29th of August 1992 in Maastricht. He moved to Lanaken, Belgium at the age of 8 , where he was educated at Koninklijk Technisch Atheneum Alicebourg. After not being selected for Medical Sciences the first time, he went to the University of Utrecht to study Pharmacy for a brief period. A year later, however, he did get selected to study Medicine, which he did at the University of Maastricht. In his second year the interest in research grew. As such he joined the research group of dr. Marc Lobbes, in which Ivo happily followed in the footsteps of dr. Lalji, as PhD student. In the year 2019 Ivo finished his studies and got his Medical Degree, soon after he began the Radiology residency with a profound interest in musculoskeletal and breast imaging. 



\section{List of Publications}




\section{List of Publications}

Lalji U.C., Jeukens C.R., Houben I.P.L., Nelemans P, van Engen R, van Wylick E, BeetsTan R, Wildberger J, Paulis L, Lobbes M. Evaluation of low-energy contrast-enhanced spectral mammography images by comparing them to full-field digital mammography using EUREF image quality criteria. Eur Radiol 2015;25(10):2813-20. doi: 10.1007/s00330-015$3695-2$.

Lobbes M.B., Lalji U.C., Nelemans P.J., Houben I.P.L., Smidt M.L., Heuts E.M., de Vries B, Wildberger J.E., Beets-Tan R.G. The quality of tumor size assessment by contrast-enhanced spectral mammography and the benefit of additional breast MRI. J Cancer 2015;6(2):144-50. doi: $10.7150 /$ jca. 10705 .

Hoffmann S, Lobbes M.B.I., Houben I.P.L., Pinker-Domenig K, Wengert G, Burgeth B, Meyer-Bäse U, Lemaitre G, Meyer-Baese A. "Computer-aided diagnosis of diagnostically challenging lesions in breast MRI: a comparison between a radiomics and a feature-selective approach," Proc. SPIE 9871, Sensing and Analysis Technologies for Biomedical and Cognitive Applications 2016, 98710H (2016);doi:10.1117/12.2228994.

Lalji, U. C., Houben, I. P.L., Prevos, R., Gommers, S., van Goethem, M., Vanwetswinkel, S., Pijnappel R., Steeman R., Frotscher C., Mok W., Nelemans P., Smidt M.L., Beets-Tan R.G., Wildberger J.E., Lobbes, M. B. (2016). Contrast-enhanced spectral mammography in recalls from the Dutch breast cancer screening program: validation of results in a large multireader, multicase study. Eur Radiol, 26(12), 4371-4379. doi:10.1007/s00330-016-4336-0.

Lobbes M.B.I., Houben I.P.L. Contrast-enhanced tomosynthesis: The best of both worlds or more of the same? Eur J Radiol. 2016 Feb;85(2):507-8. doi: 10.1016/j.ejrad.2015.11.024.

Houben, I. P. L., van Berlo, C.J.L.Y., Bekers, O., Nijssen, E. C., Lobbes, M. B. I., Wildberger, J. E. (2017). Assessing the Risk of Contrast-Induced Nephropathy Using a Finger Stick Analysis in Recalls from Breast Screening: The CINFIBS Explorative Study. Contrast Media Mol Imaging, 2017, 5670384. doi:10.1155/2017/5670384. 
Houben, I. P. L., Van de Voorde, P.V., Jeukens, C.R.L.P.N., Wildberger, J. E., Kooreman, L. F., Smidt, M. L., Lobbes, M. B. I. Contrast-enhanced spectral mammography as work-up tool in patients recalled from breast cancer screening has low risks and might hold clinical benefits. Eur J Radiol, 2017;94, 31-37. doi:10.1016/j.ejrad.2017.07.004.

Lobbes M.B.I., Hecker J, Houben I.P.L., Pluymakers R, Jeukens C, Lalji U.C., Gommers S, Wildberger J.E., Nelemans P.J. Evaluation of single-view contrast-enhanced mammography as novel reading strategy: a non-inferiority feasibility study. Eur Radiol 2019;29(11):6211-19. doi: 10.1007/s00330-019-06215-7.

van Geel K, Kok E.M., Krol J.P., Houben I.P.L., Thibault F.E., Pijnappel R.M., van Merriënboer J.J.G., Lobbes M.B.I. Reversal of the hanging protocol of Contrast Enhanced Mammography leads to similar diagnostic performance yet decreased reading times. Eur $\mathrm{J}$ Radiol. 2019 Aug;117:62-68. doi: 10.1016/j.ejrad.2019.05.013.

Houben, I. P.L., Vanwetswinkel, S., Kalia, V., Thywissen, T., Nelemans, P. J., Heuts, E. M., Smidt M.L., Meyer-Baese A., Wildberger J.E., Lobbes M.B.I. Contrast-enhanced spectral mammography in the evaluation of breast suspicious calcifications: diagnostic accuracy and impact on surgical management. Acta Radiol, 2019;60(9), 1110-1117. doi: $10.1177 / 0284185118822639$.

Neeter, L.M.F.H., Houben, I. P. L., Nelemans, P. J., Van Nijnatten, T. J. A., Pijnappel, R. M., Frotscher, C., Osinga-de Jong M, Sanders F, Van Dalen T, Raat H.P.J., Essers B.A.B., Wildberger J.E., Smidt M.L., Lobbes, M. B. I. Rapid Access to Contrast-Enhanced spectral mammogRaphy in women recalled from breast cancer screening: the RACER trial study design. Trials, 2019;20(1), 759. doi:10.1186/s13063-019-3867-5.

van Nijnatten T.J.A., Smidt M.L., Goorts B, Samiei S, Houben I.P.L., Wildberger J.E. Can high school students help to improve breast radiologists in detecting missed breast cancer lesions on full-field digital mammography?.J Cancer. 2019;10(3):765-771. doi:10.7150/jca.30494 
